\title{
VIABILIDADE CELULAR DE Saccharomyces cerevisiae CULTIVADA EM ASSOCIAÇÃO COM BACTÉRIAS CONTAMINANTES DA FERMENTAÇÃO ALCOÓLICA
}

\author{
THAIS DE PAULA NOBRE
}

\begin{abstract}
Dissertação apresentada à Escola Superior de Agricultura "Luiz de Queiroz", Universidade de São Paulo, para obtenção do título de Mestre em Ciências. Área de Concentração: Ciências e Tecnologia de Alimentos.
\end{abstract}

PIRACICABA

Estado de São Paulo - Brasil

Agosto - 2005 


\title{
VIABILIDADE CELULAR DE Saccharomyces cerevisiae CULTIVADA EM ASSOCIAÇÃO COM BACTÉRIAS CONTAMINANTES DA FERMENTAÇÃO ALCOÓLICA
}

\section{THAIS DE PAULA NOBRE}

Engenheiro Agrônomo

Orientador: Prof. Dr. ANDRÉ RICARDO ALCARDE

\begin{abstract}
Dissertação apresentada à Escola Superior de Agricultura "Luiz de Queiroz", Universidade de São Paulo, para obtenção do título de Mestre em Ciências. Área de Concentração: Ciências e Tecnologia de Alimentos.
\end{abstract}

PIRACICABA

Estado de São Paulo - Brasil

Agosto - 2005 
Dados Internacionais de Catalogação na Publicação (CIP) DIVISÃO DE BIBLIOTECA E DOCUMENTAÇÃO - ESALQ/USP

Nobre, Thais de Paula

Viabilidade celular de Saccharomyces cerevisiae cultivada em associação com

bactérias contaminantes da fermentação alcoólica. / Thais de Paula Nobre. - - Piracicaba 2005.

90p.

Dissertação (Mestrado) - - Escola Superior de Agricultura Luiz de Queiroz, 2005.

1. Bacilos 2. Fermentação alcoólica 3. Lactobacillus 4. Leveduras 5. Saccharomyces I. Título

CDD 660.28449

"Permitida a cópia total ou parcial deste documento, desde que citada a fonte - O autor" 
Aos meus pais, AMAURY e MARIA LINA,

pela confiança depositada, pela

oportunidade de estudo e apoio nas horas

mais difíceis.

OFEREÇO.

Aos meus irmãos, HOMERO e NATÁLIA,

e ao GUILHERME, pelo companheirismo, carinho e apoio desde o início.

DEDICO. 


\section{AGRADECIMENTOS}

À Deus, pela existência e força para completar mais esta etapa da vida.

À Universidade Federal de São Carlos (UFSCar), em especial ao Campus de Ciências Agrárias (CCA), pela formação profissional e apoio de seus funcionários e professores.

À Escola Superior de Agricultura "Luiz de Queiroz" (ESALQ), em especial ao Departamento de Agroindústria Alimentos e Nutrição (LAN) pelo apoio de seus funcionários e professores.

À Fundação de Amparo a Pesquisa do Estado de São Paulo (FAPESP) pela bolsa de estudos concedida durante o curso de mestrado.

Ao Prof. Dr. André Ricardo Alcarde, pela orientação e apoio durante a realização deste trabalho.

Ao Prof. Dr. Jorge Horii, pela amizade, orientação e incentivo durante a realização deste trabalho.

À Profa. Dra. Sônia Maria de Stefano Piedade pela colaboração nas análises estatísticas. 
À Profa. Dra. Sandra Helena da Cruz e ao Prof. Dr. Jorge José Corrêa Lopes pelas valiosas sugestões.

Às bibliotecárias Beatriz Helena Giongo e Midiam Gustinelli, pela amizade e auxílio na organização das referências bibliográficas.

Ao funcionário do Departamento de Agroindústria Alimentos e Nutrição (LAN), Luiz Carlos Rodrigues pelo auxílio na elaboração das figuras.

À todos os funcionários e técnicos do Setor de Açúcar e Álcool do Departamento de Agroindústria Alimentos e Nutrição (LAN), em especial à Daniele, Dito, Fábio, Flora, Gil, Joana, Pedrinho, Regina, Rose, Sylvino e Vana, pelo auxílio, amizade e incentivo.

À todos amigos(as), Ana Claudia, André, Antonio, Caio, Cindy, Giuliano, José Rubens, Mariana, Mateus, Murilo, Nilo, Pamela e Vivian, pelo apoio em todos os momentos.

À todos meus familiares que me ajudaram nos momentos de alegria e tristeza.

À todos aqueles que contribuíram direta ou indiretamente para a realização deste trabalho.

Muito Obrigada! 


\section{SUMÁRIO}

Página

LISTA DE FIGURAS ................................................................... viii

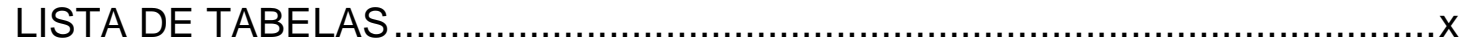

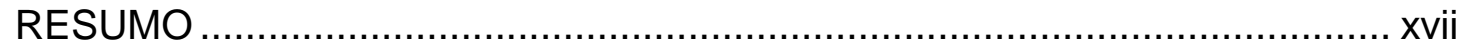

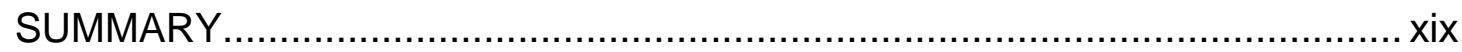

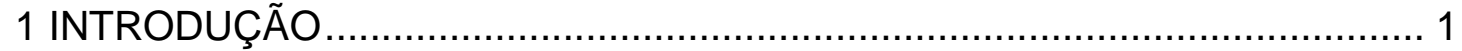

2 REVISÃO DE LITERATURA......................................................... 4

2.1 Contaminantes do processo de produção de etanol ................................. 4

2.2 Influência dos contaminantes........................................................... 6

2.3 Interação entre bactérias e leveduras .............................................. 8

2.4 Controle dos contaminantes do processo de produção de etanol .............. 10

2.5 Metodologias alternativas de cultivo de microrganismos ......................... 12

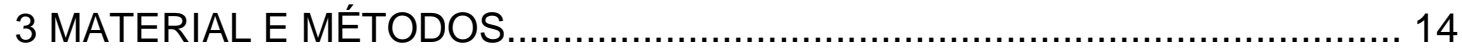

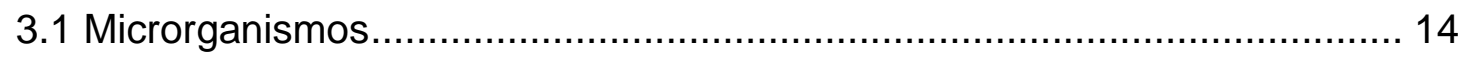

3.2 Meios de cultivo para manutenção, reativação, crescimento e plaqueamento dos microrganismos ................................................. 14

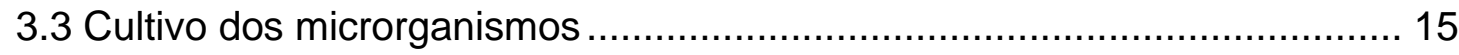

3.3.1 Cultivo de Saccharomyces cerevisiae ............................................ 15

3.3.2 Cultivo das bactérias................................................................. 17

3.4 Procedimento para obtenção de culturas mistas de bactérias e Saccharomyces cerevisiae ......................................................... 17

3.4.1 Culturas mistas com bactérias ativas............................................... 19

3.4.2 Culturas mistas com bactérias tratadas ......................................... 19

3.5 Determinações físico-químicas .................................................. 23 
3.5.1 Determinação da acidez total....................................................... 23

3.5.2 Determinação da acidez volátil ....................................................... 24

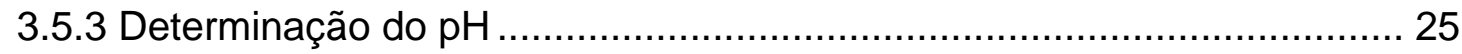

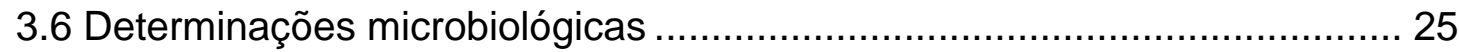

3.6.1 Viabilidade celular, brotamento e população de células da levedura S. cerevisiae...................................................................... 25

3.6.2 Plaqueamentos dos microrganismos ......................................... 26

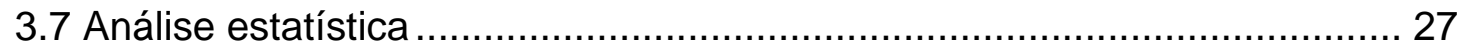

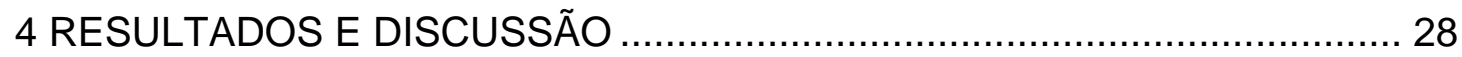

4.1 Cultivos mistos de S. cerevisiae e bactérias ativas................................. 28

4.2 Cultivos mistos de S. cerevisiae e bactérias tratadas ............................ 42

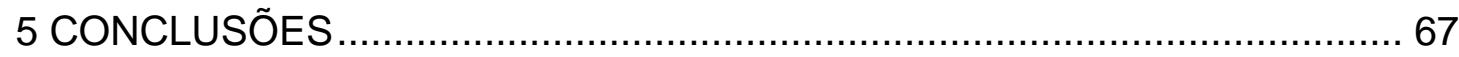

REFERÊNCIAS BIBLIOGRÁFICAS ................................................. 68

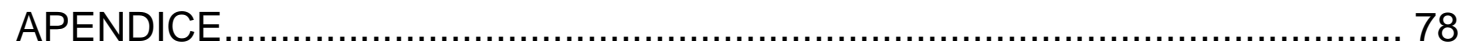




\section{LISTA DE FIGURAS}

Página

1 Esquema do cultivo de Saccharomyces cerevisiae .................................. 16

2 Esquema do cultivo das bactérias. ........................................................ 18

3 Procedimento para obtenção de culturas mistas de bactérias ativas e Saccharomyces cerevisiae.

4 Procedimento para obtenção de culturas mistas de bactérias tratadas

e Saccharomyces cerevisiae.

5 Variações das determinações físico-químicas durante o cultivo misto

de S. cerevisia com as bactérias ativas

6 Variações das determinações microbiológicas durante o cultivo misto de $S$. cerevisia com as bactérias ativas.

7 Variações das determinações físico-químicas durante o cultivo misto de S. cerevisia com as bactérias tratadas pelo calor úmido.

8 Variações das determinações físico-químicas durante o cultivo misto de S. cerevisia com as bactérias tratadas pelo antimicrobiano Kamoran $\mathrm{HJ}$.

9 Variações das determinações físico-químicas durante o cultivo misto de S. cerevisia com as bactérias tratadas por irradiação.

10 Variações das determinações microbiológicas durante o cultivo misto de S. cerevisia com as bactérias tratadas pelo calor úmido 56

11 Variações das determinações microbiológicas durante o cultivo misto de $S$. cerevisia com as bactérias tratadas pelo antimicrobiano Kamoran $\mathrm{HJ}$ 
12 Variações das determinações microbiológicas durante o cultivo misto de S. cerevisia com as bactérias tratadas com irradiação 


\section{LISTA DE TABELAS}

Página

1 Contagem bacteriana inicial e final dos cultivos mistos de bactérias ativas e leveduras

2 Teste de Tukey para as médias de acidez total comparando os microrganismos e os períodos, em cultura mista de $S$. cerevisiae e bactérias ativas

3 Teste de Tukey para as médias de acidez volátil comparando os microrganismos e os períodos, em cultura mista de S. cerevisiae e bactérias ativas

4 Teste de Tukey para as médias de $\mathrm{pH}$, comparando os microrganismos e os períodos, em cultura mista de S. cerevisiae e bactérias ativas 32

5 Teste de Tukey para as médias de viabilidade celular de $S$. cerevisiae, comparando os microrganismos e os períodos, em cultura mista de $S$. cerevisiae e bactérias ativas 37

6 Teste de Tukey para as médias de taxa de brotamento de $S$. cerevisiae, comparando os microrganismos e os períodos, em cultura mista de $S$. cerevisiae e bactérias ativas 38

7 Teste de Tukey para as médias de população de células de $S$. cerevisiae, comparando os microrganismos e os períodos, em cultura mista de $S$. cerevisiae e bactérias ativas 39

8 Eficiência do tratamento calor úmido 43

9 Eficiência do tratamento antimicrobiano com Kamoran $\mathrm{HJ}$. 43

10 Eficiência do tratamento irradiação 
11 Contagem bacteriana inicial e final dos cultivos mistos de bactérias tratadas com antimicrobiano Kamoran $\mathrm{HJ}$ e S. cerevisiae. 45

12 Contagem bacteriana inicial e final dos cultivos mistos de bactérias tratadas com radiação gama e $S$. cerevisiae 45

13 Teste de Tukey para as médias de acidez total, comparando os microrganismos e os períodos, em cultura mista de S. cerevisiae e bactérias tratadas com calor 51

14 Teste de Tukey para as médias de acidez total, comparando os microrganismos e os períodos, em cultura mista de $S$. cerevisiae e bactérias tratadas com Kamoran $\mathrm{HJ}$.

15 Teste de Tukey para as médias de acidez total, comparando os microrganismos e os períodos, em cultura mista de $S$. cerevisiae e bactérias tratadas com irradiação

16 Teste de Tukey para as médias de acidez volátil, comparando os microrganismos e os períodos, em cultura mista de S. cerevisiae e bactérias tratadas com calor

17 Teste de Tukey para as médias de acidez volátil, comparando os microrganismos e os períodos, em cultura mista de S. cerevisiae e bactérias tratadas com Kamoran $\mathrm{HJ}$.

18 Teste de Tukey para as médias de acidez volátil, comparando os microrganismos e os períodos, em cultura mista de S. cerevisiae e bactérias tratadas com irradiação 53

19 Teste de Tukey para as médias de $\mathrm{pH}$, comparando os microrganismos e os períodos, em cultura mista de S. cerevisiae e bactérias tratadas com calor 54

20 Teste de Tukey para as médias de $\mathrm{pH}$, comparando os microrganismos e os períodos, em cultura mista de $S$. cerevisiae e bactérias tratadas com Kamoran $\mathrm{HJ}$ 
21 Teste de Tukey para as médias de $\mathrm{pH}$, comparando os microrganismos e os períodos, em cultura mista de S. cerevisiae e bactérias tratadas com irradiação

22 Teste de Tukey para as médias de viabilidade celular de $S$. cerevisiae, comparando os microrganismos e os períodos, em cultura mista de $S$. cerevisiae e bactérias tratadas com calor 59

23 Teste de Tukey para as médias de viabilidade celular de $S$. cerevisiae, comparando os microrganismos e os períodos, em cultura mista de $S$. cerevisiae e bactérias tratadas com Kamoran $\mathrm{HJ}$ 60

24 Teste de Tukey para as médias de viabilidade celular de $S$. cerevisiae, comparando os microrganismos e os períodos, em cultura mista de S. cerevisiae e bactérias tratadas com irradiação 60

25 Teste de Tukey para as médias de taxa de brotamento de $S$. cerevisiae, comparando os microrganismos e os períodos, em cultura mista de $S$. cerevisiae e bactérias tratadas com calor 61

26 Teste de Tukey para as médias de taxa de brotamento de $S$. cerevisiae, comparando os microrganismos e os períodos, em cultura mista de $S$. cerevisiae e bactérias tratadas com Kamoran $\mathrm{HJ}$

27 Teste de Tukey para as médias de taxa de brotamento de $S$. cerevisiae, comparando os microrganismos e os períodos, quando em cultura mista de $S$. cerevisiae e bactérias tratadas com irradiação

28 Teste de Tukey para as médias de população de células de $S$. cerevisiae, comparando os microrganismos e os períodos, em cultura mista de $S$. cerevisiae e bactérias tratadas com calor 62 
29 Teste de Tukey para as médias de população de células de $S$. cerevisiae, comparando os microrganismos e os períodos, em cultura mista de $S$. cerevisiae e bactérias tratadas com Kamoran $\mathrm{HJ}$

30 Teste de Tukey para as médias de população de células de $S$. cerevisiae, comparando os microrganismos e os períodos, em cultura mista de S. cerevisiae e bactérias tratadas com irradiação 63

31 Comparação dos meios de cultivo convencionais e alternativo (MCC-agar) nas contagens microbiológicas no início $(0 \mathrm{~h})$ e ao final $(72 \mathrm{~h})$ do período de incubação das culturas mistas de bactérias e $S$. cerevisiae

32 Resultados das determinações físico-químicas e microbiológicas do $1^{0}$ ensaio dos cultivos mistos de $S$. cerevisiae com bactérias ativas

33 Resultados das determinações físico-químicas e microbiológicas do $2^{\circ}$ ensaio dos cultivos mistos de $S$. cerevisiae e com bactérias ativas 80

34 Resultados das determinações físico-químicas e microbiológicas do $3^{\circ}$ ensaio dos cultivos mistos de $S$. cerevisiae com bactérias ativas

35 Resultados das determinações físico-químicas e microbiológicas do $1^{\circ}$ ensaio realizado com os cultivos mistos de $S$. cerevisiae com bactérias tratadas com calor úmido 82

36 Resultados das determinações físico-químicas e microbiológicas do $2^{\circ}$ ensaio realizado com os cultivos mistos de $S$. cerevisiae com bactérias tratadas com calor úmido 83

37 Resultados das determinações físico-químicas e microbiológicas do $1^{\circ}$ ensaio realizado com os cultivos mistos de $S$. cerevisiae com bactérias tratadas com antimicrobiano Kamoran $\mathrm{HJ}$ 
38 Resultados das determinações físico-químicas e microbiológicas do $2^{\circ}$ ensaio realizado com os cultivos mistos de $S$. cerevisiae com bactérias tratadas com antimicrobiano Kamoran $\mathrm{HJ}$ 85

39 Resultados das determinações físico-químicas e microbiológicas do $1^{\circ}$ ensaio realizado com os cultivos mistos de $S$. cerevisiae com bactérias tratadas com radiação gama 86

40 Resultados das determinações físico-químicas e microbiológicas do $2^{\circ}$ ensaio realizado com os cultivos mistos de $S$. cerevisiae com bactérias tratadas com radiação gama

41 Média geral, $\mathrm{R}^{2}$, coeficiente de variação e desvio padrão para as variáveis quando em cultivo misto de bactérias ativas e $S$. cerevisiae. 88

42 Média geral, $R^{2}$, coeficiente de variação e desvio padrão para as variáveis em cultivo misto de bactérias tratadas com calor e $S$. cerevisiae 88

43 Média geral, $\mathrm{R}^{2}$, coeficiente de variação e desvio padrão para as variáveis quando em cultivo misto de bactérias tratadas com Kamoran $\mathrm{HJ}$ e S. cerevisiae 88

44 Média geral, $\mathrm{R}^{2}$, coeficiente de variação e desvio padrão para as variáveis quando em cultivo misto de bactérias tratadas com irradiação e S. cerevisiae. 88

45 Quadrado Médio (Q.M.) da análise de variância, seguido da significância do teste $F$ dos fatores Microrganismo (Micro), Período (Per) e Interação (Micro * Per) para todas as variáveis em cultivo misto de bactérias ativas e $S$. cerevisiae 89

46 Quadrado Médio (Q.M.) da análise de variância, seguido da significância do teste $F$ dos fatores Microrganismo (Micro), Período (Per) e Interação (Micro * Per) para todas as variáveis em cultivo misto de bactérias tratadas com calor e $S$. cerevisiae. 89 
47 Quadrado Médio (Q.M.) da análise de variância, seguido da significância do teste $F$ dos fatores Microrganismo (Micro), Período (Per) e Interação (Micro * Per) para todas as variáveis em cultivo misto de bactérias tratadas com Kamoran $\mathrm{HJ}$ e $\mathrm{S}$. cerevisiae. 89

48 Quadrado Médio (Q.M.) da análise de variância, seguido da significância do teste $F$ dos fatores Microrganismo (Micro), Período (Per) e Interação (Micro * Per) para todas as variáveis em cultivo misto de bactérias tratadas com irradiação e $S$. cerevisiae.... 89

49 Média geral, $\mathrm{R}^{2}$, coeficiente de variação e desvio padrão para as contagens microbiológicas quando em comparação dos meios de cultivo convencionais e alternativo (MCC-agar) no início $(0 \mathrm{~h})$ do período de incubação das culturas mistas de bactérias e $S$. cerevisiae 90

50 Média geral, $\mathrm{R}^{2}$, coeficiente de variação e desvio padrão para as contagens microbiológicas quando em comparação dos meios de cultivo convencionais e alternativo (MCC-agar) no final (72 h) do período de incubação das culturas mistas de bactérias e $S$. cerevisiae. 90

51 Quadrado Médio (Q.M.) da análise de variância, seguido da significância do teste $F$ para as contagens microbiológicas quando em comparação dos meios de cultivo convencionais e alternativo (mcc-agar) no início (0 h) do período de incubação das culturas mistas de bactérias e $S$. cerevisiae 90 
52 Quadrado Médio (Q.M.) da análise de variância, seguido da significância do teste $F$ para as contagens microbiológicas quando em comparação dos meios de cultivo convencionais e alternativo (mcc-agar) no final (72 h) do período de incubação das culturas mistas de bactérias e $S$. cerevisiae 


\title{
VIABILIDADE CELULAR DE Saccharomyces cerevisiae CULTIVADA EM ASSOCIAÇÃO COM BACTÉRIAS CONTAMINANTES DA FERMENTAÇÃO ALCOÓLICA
}

\author{
Autora: THAIS DE PAULA NOBRE \\ Orientador: Prof. Dr. ANDRÉ RICARDO ALCARDE
}

\section{RESUMO}

O objetivo deste trabalho foi estudar a influência de bactérias dos gêneros Bacillus e Lactobacillus, bem como de seus produtos metabólicos, na redução da viabilidade celular Saccharomyces cerevisiae, quando em cultura mista de levedura e bactérias ativas e tratadas. Também foi avaliado um meio alternativo de cultivo de bactérias e leveduras, constituído de caldo de cana diluído a $5^{\circ}$ brix e suplementado com extrato de levedura e peptona. As bactérias Bacillus subtilis, Bacillus coagulans, Bacillus stearothermophilus, Lactobacillus fermentum e Lactobacillus plantarum foram cultivadas em associação com Saccharomyces cerevisiae (cepa Y-904) por $72 \mathrm{~h}$ a $32^{\circ} \mathrm{C}$, sob agitação. A viabilidade celular, a taxa de brotamento e a população de células da levedura, a acidez total, a acidez volátil e o pH do meio foram determinados às $0,24,48$ e $72 \mathrm{~h}$ do cultivo misto. Também foi determinada a população inicial e final dos microrganismos através de plaqueamento em profundidade, em meio de cultivo tradicional (PCA para os Bacillus, MRS-agar para os Lactobacillus e YEPD-agar para S. cerevisiae) e no meio constituído de caldo de cana. As 
culturas de bactéria foram tratadas através do calor (esterilização em autoclave a $120^{\circ} \mathrm{C}$ por 20 minutos), de agente antimicrobiano (Kamoran $\mathrm{HJ}$ na concentração de 3,0 ppm) ou da irradiação (radiação gama, com doses de 5,0 kGy para os Lactobacillus e 15,0 kGy para os Bacillus). Os resultados mostraram que apenas os meios de cultivo mais acidificados (com maiores concentrações de acidez total e volátil, e menores valores de $\mathrm{pH}$ ), contaminados com as bactérias ativas $L$. fermentum e $B$. subtilis, provocaram diminuição da viabilidade celular da levedura. Excetuando a bactéria $B$. subtilis inativada por radiação, as demais bactérias tratadas pelos diferentes processos (calor, radiação e antimicrobiano) não causaram diminuição da viabilidade celular e da população das leveduras, indicando que a presença isolada dos metabólitos celulares dessas bactérias não foi suficiente para reduzir a porcentagem de células vivas e a densidade populacional da levedura. Para todos os microrganismos, as contagens obtidas com o cultivo em meio à base de caldo de cana foram semelhantes às obtidas nos meios tradicionais, provavelmente porque o meio alternativo simula a composição do mosto de caldo de cana-de-açúcar, do qual as bactérias foram isoladas do processo industrial de produção de etanol. Sendo assim, o meio de cultivo à base de caldo de cana-de-açúcar pôde substituir os meios tradicionais de cultivo da levedura e das bactérias testadas neste trabalho. 


\title{
CELLULAR VIABILITY OF Saccharomyces cerevisiae CULTIVATED IN ASSOCIATION WITH CONTAMINATES BACTERIAS OF ALCOHOLIC FERMENTATION
}

\author{
Author: THAIS DE PAULA NOBRE \\ Adviser: Prof. Dr. ANDRÉ RICARDO ALCARDE
}

\section{SUMMARY}

The aim of this work was to study the influence of the bacteria Bacillus and Lactobacillus, as well as their metabolic products, in reduction of cellular viability of Saccharomyces cerevisiae, when in mixed culture of yeast and active and treated bacteria. Also was to evaluated an alternative medium (MCC) for the cultivation of bacteria and yeast, constituted of sugarcane juice diluted to $5^{\circ}$ Brix and supplemented with yeast extract and peptone. The bacteria Bacillus subtilis, Bacillus coagulans, Bacillus stearothermophilus, Lactobacillus fermentum and Lactobacillus plantarum were cultivated in association with yeast Saccharomyces cerevisiae (strain Y-904) for $72 \mathrm{~h}$ on $32^{\circ} \mathrm{C}$, under agitation. The cellular viability, budding rate and population of $S$. cerevisiae, the total acidity, volatile acidity and $\mathrm{pH}$ of culture were determined from $0,24,48$ e $72 \mathrm{~h}$ of mixed culture. Also were determined the initial and final of microorganism population across the pour plate method, in traditional culture medium (PCA for Bacillus, MRS-agar for Lactobacillus and YEPD-agar for yeast $S$. cerevisiae) and in medium constituted of sugarcane juice. The bacteria cultures were treated by heat sterilization $\left(120^{\circ} \mathrm{C}\right.$ for 20 minutes), antibacterial agent (Kamoran $\mathrm{HJ}$ in 
concentration 3,0 ppm) or irradiation (radiation gama, with doses of 5,0 kGy for Lactobacillus and 15,0 kGy for Bacillus). The results of the present research showed that just the culture mediums more acids (with higher concentrations of total and volatile acidity, and smaller values of $\mathrm{pH}$ ), contaminated with active bacteria $L$. fermentum and $B$. subtilis, caused reduction on yeast cellular viability. Except the bacteria $B$. subtilis treated with radiation, the others bacteria treated by different procedures (heat, radiation e antibacterial) did not cause reduction on yeast cellular viability and population, indicating that the isolated presence of the cellular metabolic of theses bacteria was not enough to reduce the percentage of the yeast live cells and a density population. For all microorganisms, the counts obtained with the cultivation medium constituted of sugarcane juice were similar obtained in traditional mediums, probably because the alternative medium simulate the composition of sugarcane must, that the bacteria were isolated in industrial process of ethanol yield. However, the culture medium constituted of sugarcane juice could be replacing traditional culture mediums of yeast and bacteria tested in this work. 


\section{INTRODUÇÃO}

A agroindústria do álcool, juntamente com a da aguardente, representa um considerável gerador econômico, sendo o setor de suma importância para o país. O Brasil tornou-se o primeiro país do mundo a desenvolver um programa de combustível alternativo em substituição à gasolina, e é o maior produtor de aguardente. Como toda a produção de álcool e de aguardente ocorre por via fermentativa, é fundamental, o conhecimento do processo que tem sido constantemente aprimorado.

A fermentação etanólica é um processo conduzido por leveduras. Entre essas, o gênero Saccharomyces, representado por linhagens de Saccharomyces cerevisiae, tem se adaptado, muito bem, às condições industriais. Entretanto, os microrganismos do ambiente que aderem à cana-de-açúcar, constituem a carga microbiana contaminante do processo e podem atingir níveis que são prejudiciais à produção de álcool.

A infecção na fermentação pode causar danos como: consumo de açúcar; formação de goma, que aumenta a viscosidade do caldo e pode causar entupimento nas tubulações, centrífugas, peneiras e trocadores de calor; floculação do fermento, que diminui a velocidade de fermentação, acarreta perda de células de leveduras pelo fundo da dorna e dificulta a operação das centrífugas; inibição e queda da viabilidade das leveduras devido às toxinas e ácidos orgânicos excretados no meio e, conseqüentemente a redução no rendimento e na produtividade da fermentação (Alterthum et al., 1984; Amorim et al., 1981; Amorim \& Oliveira, 1982; Euchi et al., 1989; Yokoya, 1991). 
Frente à importância destes contaminantes, têm sido realizados trabalhos no sentido de isolar e caracterizar os microrganismos para que se possa combatêlos do processo. Estes trabalhos mostram que as bactérias do grupo Grampositivo são os microrganismos contaminantes que predominam na fermentação alcoólica, sendo os gêneros Bacillus e Lactobacillus os de maior ocorrência (Gallo, 1989; Gallo e Canhos, 1991; Rodini, 1985; Rosales, 1989; Skinner e Leathers, 2004).

Os métodos tradicionais empregados pela indústria sucro-alcooleira para o tratamento do mosto com o objetivo de reduzir a sua carga microbiana contaminante preconizam o uso de antibióticos e de ácido sulfúrico concentrado. A sensibilidade das bactérias contaminantes frente a novos agentes antimicrobianos tem sido largamente estudada (Alcarde, 1995; Alcarde, 2000; Oliveira et al., 1996; Stupiello, 1993). Porém, o mecanismo da interação bactérialevedura e o meio de cultura são ainda pouco conhecidos, principalmente com relação à influência da bactéria e das transformações do meio sobre a viabilidade celular da levedura.

O desenvolvimento de técnicas mais simples, acessíveis e econômicas de cultivo de microrganismos têm sido objetivo de pesquisas atuais (Taniwaki, 1996). Meios de cultura caros e de composição complexa, principalmente os indicados para o crescimento de Lactobacillus, podem ser substituídos por meios à base de caldo de cana-de-açúcar suplementado, tornando a metodologia de plaqueamento mais econômica e acessível (Freguglia, 1997; Horii, 1983).

O presente trabalho teve como objetivos:

- Avaliar a influência de bactérias dos gêneros Bacillus e Lactobacillus, bem como de seus produtos metabólicos, na redução da viabilidade celular da levedura Saccharomyces cerevisiae, quando em cultura mista de levedura e bactérias.

- Estudar o cultivo de bactérias e levedura em um meio alternativo constituído de caldo de cana diluído a $5^{\circ}$ brix e suplementado com extrato 
de levedura e peptona. E testar se os tradicionais meios de cultivo dos microrganismos testados podem ser substituídos por meio de cultura à base de caldo de cana-de-açúcar suplementado, o qual é mais econômico e acessível.

A influência dos produtos metabólicos sobre a viabilidade celular da levedura foi estudada através de cultivo misto de levedura ativa e bactérias tratadas por calor, antimicrobiano e irradiação. Com isso, testou-se a hipótese de tanto as bactérias contaminantes da fermentação alcoólica quanto os seus produtos metabólicos exercerem influência negativa sobre a viabilidade celular da levedura fermentativa, variando conforme as condições de acidez do meio.

Os parâmetros analisados foram: $\mathrm{pH}$, acidez total e volátil do meio, e viabilidade celular, taxa de brotamento e população de células da levedura. 


\section{REVISÃO DE LITERATURA}

\subsection{Contaminantes do processo de produção de etanol}

Leveduras e bactérias lácticas são freqüentemente encontradas juntas em ecossistemas naturais e podem competir pelos mesmos nutrientes (Alexander, 1971).

Não é recente a preocupação de muitos autores com a contaminação bacteriana no processo de extração de caldo e na indústria da fermentação alcoólica, particularmente na produção de bebidas, sendo importante ressaltar os trabalhos de Pasteur no fim do século retrasado com cervejas e vinhos contaminados, que permitiram grande desenvolvimento da microbiologia (de acordo com o artigo Controle..., 1983).

Amorim \& Oliveira (1982) citam como principais contaminantes da fermentação alcoólica, bactérias dos gêneros Acetobacter, Lactobacillus, Bacillus, Leuconostoc e Streptococcus.

Estudos de Rodini (1985) em mosto fermentado constataram uma contaminação de até $10^{7}$ bactérias por $\mathrm{mL}$. As bactérias Gram-positivas abrangeram $65 \%$ do total, sendo $62 \%$ delas pertencentes ao gênero Bacillus ( $B$. subtilis, B. megaterium e B. coagulans). Silva (1988), estudando a microbiota bacteriana do caldo clarificado, pasteurizado e pré-resfriado, encontrou bactérias dos gêneros Lactobacillus, Leuconostoc e Bacillus, com cerca de 38 \%, 12 \% e 3 $\%$, respectivamente.

Numa amostragem das etapas da fermentação, os gêneros que predominaram no processo foram Lactobacillus $(45,04 \%)$, Leuconostoc $(14,41 \%)$, 
Bacillus (9,46\%), Acetobacter (7,21\%), Enterobacter (6,75\%) e Sporolactobacillus (3,60\%), entre outros (Rosales, 1989).

Gallo (1989) constatou a predominância de bactérias Gram-positivas (98,52\%), de bastonetes $(87,76 \%)$ e de não esporulados $(73,95 \%)$ num estudo de caracterização da microbiota bacteriana em amostras de leite de levedura diluído antes e após o tratamento ácido, de mosto de alimentação e de vinho final. O mesmo autor, concluiu que o gênero Lactobacillus foi o mais freqüente $(59,75 \%)$, com a identificação de: L. fermentum, L. helveticus, L. plantarum, L. buchneri e $L$. acidophilus, entre outros. E o gênero Bacillus correspondeu a 26,58\% das bactérias identificadas, com as seguintes espécies: $B$. coagulans, $B$. stearothermophilus, B. megaterium, B. brevis, B. lentus e B. pasteurii.

Análises em leite de levedura sem tratamento ácido apresentaram $L$. fermentum (62\%), L. murinus (9\%), L. vaccinostercus (9\%), L. plantarum (2\%) e Leuconostoc (2\%) (Oliva-Neto, 1990).

Resultados do estudo de caracterização da microbiota contaminante da produção de álcool combustível utilizando o milho como matéria-prima, demonstraram que prevalecem bactérias láticas, particularmente Lactobacillus sp. com cerca de $40 \%$ dos contaminantes totais isolados. Outros isolados presentes com menos freqüência incluem os gêneros Clostridium, Eubacterium, Lactococcus, Leuconostoc, Pediococcus, e Weisella, segundo Skinner e Leathers (2004).

A maioria dos trabalhos identificou e tornou evidente a predominância de bactérias Gram-positiva e em forma de bastonetes no processo industrial de fermentação alcoólica, com destaque para os gêneros Bacillus e Lactobacillus.

Contudo, além da possível contaminação da matéria-prima proveniente do campo, as condições peculiares das etapas do processo de cada indústria selecionam determinadas espécies ou linhagens de microrganismos que são favorecidos por tais condições e que não são problemas em outras destilarias (Cherubin, 2003). 


\subsection{Influência dos contaminantes}

De acordo com a equação estequiométrica de Gay-Lussac, citado por Kunkee e Amerine (1970), o rendimento da fermentação alcoólica é expresso em quantidade de produto formado (etanol) por unidade de açúcar consumido. Em função disto, todo açúcar que não é convertido em álcool, e sim em outros produtos, faz com que ocorra uma diminuição neste rendimento.

O consumo da sacarose resultando na formação dos ácidos lático e acético, como os principais ácidos orgânicos formados, é um dos principais prejuízos causados pelas bactérias contaminantes no processo de produção de etanol (Bevan e Bond, 1971). Outros compostos como a formação de goma, que aumenta a viscosidade do caldo e pode causar entupimento nas tubulações, centrífugas, peneiras e trocadores de calor; a floculação do fermento, que diminui a velocidade de fermentação, acarreta perda de células de leveduras pelo fundo da dorna e dificulta a operação das centrífugas também são associados por diversos autores à perdas no rendimento alcoólico (Alterthum et al., 1984; Amorim \& Oliveira, 1982; Amorim et al., 1981; Euchi et al., 1989; OlivaNeto e Yokoya, 1997; Yokoya, 1991).

Amorim et al. (1981) citaram que, quando a contaminação bacteriana atinge níveis superiores a $1,0 \times 10^{7}$ células $/ \mathrm{mL}$ de mosto, pode ocorrer uma significativa queda no rendimento alcoólico. Os autores associaram às bactérias contaminantes perdas a níveis de até $55 \%$ do valor teórico. Alterthum et al. (1984) verificaram quedas no rendimento alcoólico variável de 14 a 90\% do teórico quando a concentração bacteriana atingiu $10^{8}$ a $10^{9}$ células $/ \mathrm{mL}$.

Amorim \& Oliveira (1982) citaram que as bactérias contaminantes causam prejuízos à fermentação e inibem o crescimento da levedura através da produção de ácido láctico e outros ácidos orgânicos. Os autores constataram queda de 60\% no rendimento de fermentações com valores de acidez entre 5 e 6 g/L; o não controle da contaminação bacteriana pode ocasionar indiretamente um abaixamento no rendimento da fermentação por dois motivos: aumento da 
viscosidade do vinho, ocasionando uma maior perda do fermento no vinho centrifugado e maior consumo de açúcar, desviando-o da produção de álcool.

Segundo Khan \& Hoq (1990) fermentações conduzidas em presença de $5,0 \times 10^{6}$ bactérias $/ \mathrm{mL}$, sendo que $5,0 \times 10^{3}$ bactérias $/ \mathrm{mL}$ eram produtoras de ácido, apresentaram rendimento $11,4 \%$ menor que quando estas não estavam presentes. Essia-Ngang et al. (1989) observaram uma redução de 30\% na produtividade em etanol da fermentação de mosto de açúcar de beterraba quando a concentração de ácido lático produzido pelas bactérias contaminantes atingiu $5,0 \mathrm{~g} / \mathrm{L}$.

Qualquer correlação entre o tamanho da contaminação bacteriana e perdas em rendimento em etanol precisa ser mais bem compreendida, embora seja óbvio que cada molécula de açúcar direcionada para a produção de ácido lático pela bactéria resulta em perdas de duas moléculas de etanol que poderiam ser produzidas pelas células de leveduras (Ingledew, 1995).

Existem controvérsias na literatura descrevendo o efeito de bactérias láticas sobre o rendimento em etanol. E apesar de uma significante soma de pesquisas na área, o efeito de bactérias lácticas em fermentações conduzidas por leveduras permanece confuso (Huang et al., 1996).

Chin e Ingledew (1994) relataram que a contaminação com aproximadamente $10^{8} \mathrm{UFC} / \mathrm{mL}$ de bactérias produtoras de ácido láctico não afetou seriamente a produtividade em etanol na fermentação de malte de trigo, mesmo com aumento gradual da concentração de ácido lático ao longo de 5 fermentações, mas ocasionou uma redução de $60 \%$ na viabilidade da levedura nas últimas fermentações.

Bayrock e Ingledew (2001), introduzindo L. paracasei como contaminante num sistema contínuo de fermentação nas proporções de 1:100, 1:1 e 70:1 com S. cerevisiae, observaram que, mesmo na maior proporção, nem a bactéria e nem seus produtos metabólicos (ácido láctico) afetaram a concentração de etanol e a viabilidade da levedura. Os mesmo autores, em 2005, desenvolveram outro trabalho a fim de complementar a publicação anterior e, novamente, observaram 
que a presença de $L$. paracasei com 3,7 × $10^{5} \mathrm{UFC} / \mathrm{mL}$ não afetou o número de células viáveis de S. cerevisiae, e ainda produziu mais $18 \%$ de etanol quando comparado com a fermentação sem a presença do contaminante.

Cherubin (2003) num experimento comparativo entre linhagens de $S$. cerevisiae em cultura pura e em cultura mista com a bactéria $L$. fermentum durante 6 reciclos fermentativos constatou que não houve relação entre contaminação bacteriana e viabilidade de levedura, nem entre contaminação bacteriana e rendimento fermentativo.

Porém não há dúvidas, de acordo com Alcarde e Yokoya (2003), que a contaminação bacteriana é um dos fatores preponderantes dentre aqueles que afetam a fermentação alcoólica industrial, posto que é o mais freqüente agente presente.

\subsection{Interação entre bactérias e leveduras}

Gilliland e Lacey (1964) e Kaneko e Yamamoto (1968) verificaram influência do ácido acético na inibição do crescimento e na queda da viabilidade celular de Saccharomyces cerevisiae quando em cultura mista com Acetobacter. Os primeiros autores também observaram este mesmo efeito em leveduras dos gêneros Pichia, Schizosaccharomyces, Zygosacharomyces, Torula, Candida e em outras espécies de Saccharomyces.

Estudando o efeito de alguns produtos secundários no sistema de fermentação, Maiorella et al. (1983) concluíram que o ácido acético e o ácido láctico causam interferências químicas na manutenção das funções celulares. Os mesmos autores observaram que a concentração de ácido acético e ácido láctico, inibiram o crescimento de Saccharomyces cerevisiae quando presente em concentrações de 0,5-9 e 10-40 g/litro, respectivamente, e uma redução de 80\% da massa de células de levedura ocorreu em concentrações de 7,5 e 38 g/litro, respectivamente. 
Alterthum et al. (1984), estudando fermentações com reciclagem de células, citaram que a elevada porcentagem de células mortas e o aumento da acidez do mosto são devidos à liberação no meio de cultura de substâncias tóxicas produzidas pelas células bacterianas, promovendo a morte da levedura ou dificultando seu desenvolvimento.

Os efeitos de alguns contaminantes e seus produtos metabólicos sobre a levedura são ainda pouco conhecidos, porém sabe-se que um nível elevado de contaminação pode causar redução na produtividade e no rendimento fermentativo devido à competição pelo substrato, à redução da viabilidade das células de levedura pela "intoxicação" por metabólitos do microrganismo contaminante e à floculação das leveduras pela ação das células bacterianas (Yokoya, 1989).

Oliva-Neto (1990), avaliando a influência da contaminação por bactérias láticas na fermentação, concluiu que a acidez total do vinho está inversamente correlacionada com a relação levedura/bactéria e diretamente correlacionada com o número de células de bactérias láticas. $\mathrm{O}$ autor ainda determinou que quando a acidez total atinge valores superiores a 4,8 $\mathrm{g} / \mathrm{L}$, expressos em ácido lático, ocorre uma correlação inversa entre a acidez e a viabilidade das leveduras e, ainda, entre a acidez e a porcentagem de brotos vivos do fermento.

Segundo Yokoya (1991) a presença de bactérias láticas na fermentação causam aumento da acidez do vinho pela produção de ácidos lático e acético, e acarretam queda na porcentagem de células vivas das leveduras.

Durante a fermentação, há queda no rendimento em etanol, as células de levedura têm seu metabolismo e crescimento inibidos; há uma menor utilização de carboidratos e um aumento da acidez pelo efeito das altas concentrações de ácido lático, de acordo com Makanjuola et al. (1992). Estes mesmos autores concluíram que uma contagem de bactérias de 4,5 × $10^{8} \mathrm{UFC} / \mathrm{mL}$ em $30 \mathrm{~h}$ resulta em uma redução de $17 \%$ no rendimento em etanol.

Freguglia (1997), estudando a viabilidade celular de $S$. cerevisiae em cultura mista com L. fermentum, observou que a presença da bactéria e/ou de 
seus produtos metabólicos reduziram a viabilidade celular da levedura em $97 \%$ e $55 \%$, respectivamente, após 12 horas de cultivo associado.

Thomas et al. (2001) pesquisaram o efeito dos lactobacilos (L. collinoides, L. fermentum, L. plantarum e L. paracaseI) em cultura mista com S. cerevisiae durante 6 reciclos de fermentação em batelada de mosto à base de milho e relataram que a presença das bactérias, pré-inoculadas no mosto 24 horas antes da inoculação das leveduras, ocasionou decréscimo acima de 22\% na produção de etanol, aumento do desvio de carboidratos para a produção de glicerol e ácido lático, queda de 55\% na viabilidade da levedura e redução na formação de massa celular de levedura. Contudo, quando as bactérias foram inoculadas ao mesmo tempo e com o mesmo nível, de $10^{7}$ células $/ \mathrm{mL}$, que as leveduras os parâmetros citados não foram significativamente afetados.

\subsection{Controle dos contaminantes do processo de produção de etanol}

Há 30 anos atrás, Silva (1975), realizou um estudo preliminar de controle da infecção de moendas através da aplicação de bactericidas. O controle microbiológico é de importância fundamental se o objetivo é produzir álcool com altos rendimentos (Amorim e Oliveira, 1982) e devido a constante presença de contaminantes durante o processo fermentativo é importante o conhecimento de fatores que possibilitem a redução dos problemas causados pela contaminação bacteriana, além das práticas usuais de tratamento ácido do creme de levedura e de aplicação de antibióticos (Cherubin, 2003).

Gallo (1989) observou uma redução média de 44,5 \% da flora bacteriana quando o fermento recebeu tratamento com ácido sulfúrico por duas horas a um pH igual a 2,0. E Alves (1994), trabalhando com mosto contaminado com uma mistura de microrganismos, observou que a eficácia da fermentação pode ser restabelecida com a aplicação dos antimicrobianos virginiamicina, penicilina e cloranfenicol. 
Alcarde (1995) e Oliveira et al. (1996), estudando o efeito do antimicrobiano Kamoran $\mathrm{HJ}$, constataram altas porcentagens de reduções populacionais em diversos microrganismos contaminantes da fermentação alcoólica. Oliveira et al. (1996), utilizando o antimicrobiano na concentração de 1 ppm, obtiveram redução populacional de 13,9\% para Bacillus subtilis; 15,6\% para Bacillus coagulans; 99,5\% para Lactobacillus fermentum e 66,3\% para Lactobacillus plantarum. Alcarde (1995), utilizando o antimicrobiano na concentração de 3 ppm, verificou redução populacional de 91,3\% para Bacillus subtilis; 37,8\% para Bacillus coagulans e $87,9 \%$ para Bacillus stearothermophilus.

Porém, antibióticos são caros e o uso de tais produtos fica restritos ao fator custo-benefício, além de requererem aplicação constante (Bevan e Bond, 1971). Atualmente, as indústrias de etanol tem considerado aceitável uma população bacteriana no mosto de cerca de $10^{5} \mathrm{UFC} / \mathrm{mL}$, não sendo economicamente viável reduzir este nível (Alcarde et al., 2003).

Considerando o crescente conceito de que as bactérias desenvolvem uma resistência aos antibióticos, segundo Narendranath e Power (2004), a estratégia de inocular uma alta taxa de leveduras é um meio de minimizar os efeitos causados pela contaminação bacteriana.

O uso da radiação ionizada pode ser uma alternativa de descontaminação do mosto de cana-de-açúcar. A irradiação pode mudar o DNA celular, afetando as funções celulares e induzir a morte das células (Urbain, 1986).

Shin e Pyun (1997), num estudo comparativo de inativação de $L$. plantarum, os resultados indicaram que a irradiação por microondas monstrou-se mais efetiva no controle da bactéria do que o método convencional de tratamento a calor $\left(50^{\circ} \mathrm{C}\right.$ por 30 minutos).

Diversos autores observaram redução da população bacteriana por radiação ionizada como Zeller el al. (1984), que estudaram a esterilização e conservação do melaço de cana-de-açúcar com doses de radiação gama de 10 kGy; Postmes et al. (1995), que esterilizaram mel contaminado com Clostridium 
botulinum e Bacillus subtilis com irradiação gama; Alcarde (2000) e Alcarde et al. (2003), que demonstraram a eficiência da redução microbiológica contaminante do mosto de cana-de-açúcar

Segundo lemma et al (2000), tanto o antimicrobiano Kamoran HJ quanto a radiação gama se mostraram eficientes na inativação de bactérias dos gêneros Bacillus e Lactobacillus contaminantes do mosto de cana-de-açúcar, sem ser observada qualquer alteração na capacidade fermentativa das leveduras, as quais foram acrescentadas após os tratamentos de inativação.

\subsection{Metodologias alternativas de cultivo de microrganismos}

O levantamento microbiológico em indústrias normalmente é feito com meios sintéticos que se apresentam práticos na manipulação, porém são onerosos. Por esta razão faz-se necessário desenvolver meios mais acessíveis e que permitam o crescimento de todas as bactérias presentes nos caldos e na fermentação (Rosales et al., 1987).

Horii (1983) desenvolveu um meio de cultivo para isolamento e contagem de bactérias lácticas contaminantes da fermentação alcoólica constituído de caldo de cana-de-açúcar clarificado, diluído a $8^{\circ}$ brix e suplementado com extrato de levedura e actidiona.

Estudos detalhados, com vários tipos de alimentos e meios de culturas servem para orientar as indústrias e os laboratórios de microbiologia sobre o meio mais adequado e para validar os meios recomendados pela ICFM (International Commission on Food Mycology) para produtos de países tropicais (Taniwaki, 1996).

Freguglia (1997) obteve resultados semelhantes de crescimento de colônias de L. fermentum em meio de cultura de caldo de cana suplementado com extrato de levedura e peptona e em meio MRS-agar. A autora concluiu que tais metodologias alternativas de contagem e cultivo são vantajosas, desde que 
os meios de cultivo e as condições sejam adaptados aos microrganismos que se deseja pesquisar. 


\section{MATERIAL E MÉTODOS}

Os ensaios foram realizados no Setor de Açúcar e Álcool do Departamento de Agroindústria, Alimentos e Nutrição da Escola Superior de Agricultura "Luiz de Queiroz" - ESALQ / USP, Piracicaba - São Paulo.

\subsection{Microrganismos}

Foram utilizadas culturas da levedura Saccharomyces cerevisiae (Y-904), da Mauri Brasil, do grupo Burns Philp, e isolados das bactérias Bacillus subtilis, Bacillus coagulans, Bacillus stearothermophilus, Lactobacillus fermentum e Lactobacillus plantarum, que fazem parte da coleção de culturas do Departamento de Agroindústria, Alimentos e Nutrição da Escola Superior de Agricultura "Luiz de Queiroz", Universidade de São Paulo.

\subsection{Meios de cultivo para manutenção, reativação, crescimento e plaqueamento dos microrganismos}

- Bactérias do gênero Bacillus: caldo GLT (glicose - 0,1\%, extrato de levedura 0,25\%, triptona - 0,5\%, água destilada) e PCA ("Plate Count Agar", caldo GLT acrescido de 1,5\% de agar).

- Bactérias do gênero Lactobacillus: caldo MRS (Lactobacilli "Man, Rogosa, Sharpe" - MRS Difco 0881-01-3) e MRS-agar (caldo MRS acrescido de 1,5\% de agar). 
- Todas as bactérias: Litmus milk - meio de cultura para manutenção das culturas de bactérias.

- Levedura S. cerevisiae: caldo YEPD (extrato de levedura - 1\%, peptona - 1\%, dextrose - 2\%, água destilada) e YEPD-agar (caldo YEPD acrescido de 1,5\% de agar).

- Todos os microrganismos: MCC e MCC-agar (MCC acrescido de 1,5\% de agar): meio à base de caldo de cana suplementado, preparado a partir de caldo de cana-de-açúcar clarificado (fervura por $20 \mathrm{~min}$, resfriamento e filtração em algodão), diluído com água destilada para 5,0 $\pm 0,1^{\circ}$ brix, suplementado com extrato de levedura (1,0\%) e peptona (1,0\%).

Todos os meios de cultura foram autoclavados por 20 minutos a $121^{\circ} \mathrm{C}$, antes de serem utilizados.

\subsection{Cultivo dos microrganismos}

\subsubsection{Cultivo de Saccharomyces cerevisiae}

A cultura de S. cerevisiae (Y-904) foi mantida em meio de cultura YEPDagar com óleo mineral, sob temperatura de refrigeração a $4^{\circ} \mathrm{C}$. Na reativação, foi retirada uma alça da cultura de manutenção e transferida para tubo de ensaio com 9,0 mL de caldo YEPD, sendo o tubo incubado a $32^{\circ} \mathrm{C}$ por $48 \mathrm{~h}$. Em seguida, nova trabsferência foi efetuada nas mesmas condições anteriores. Após a incubação, o conteúdo de dois tubos de ensaio $(20 \mathrm{~mL})$, foi transferido para erlenmeyer contendo $1000 \mathrm{~mL}$ do meio $\mathrm{MCC}$ e incubado a $32^{\circ} \mathrm{C}$ por $48 \mathrm{~h}$ (Figura 1). 


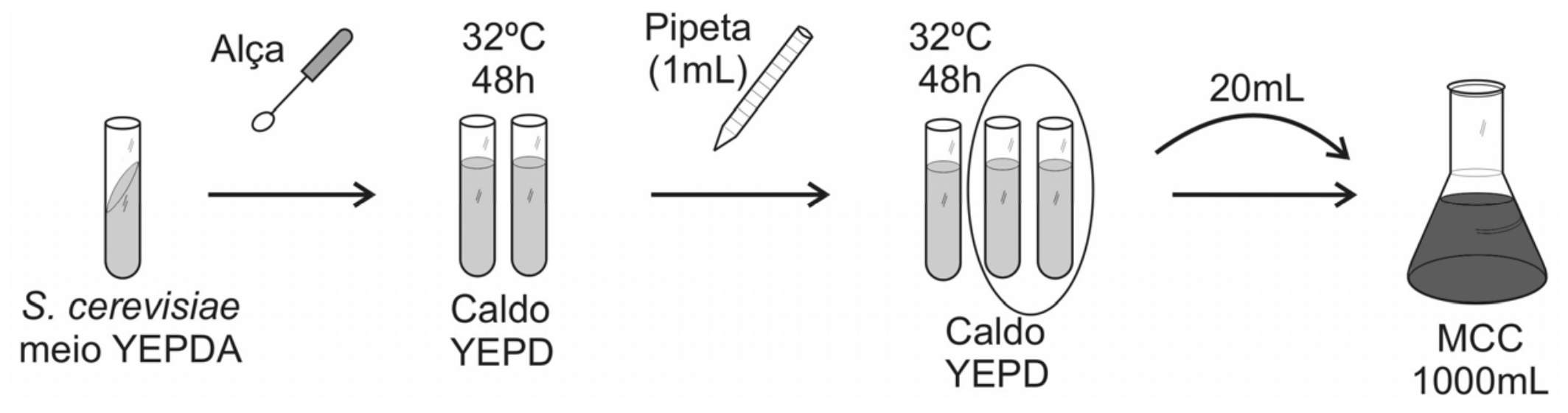

Figura 1 - Esquema do cultivo de Saccharomyces cerevisiae 


\subsubsection{Cultivo das bactérias}

As culturas das bactérias dos gêneros Bacillus (B. subtilis, B. coagulans, e B. stearothermophilus) e Lactobacillus (L. fermentum e L. plantarum) foram mantidas em meio Litmus Milk, sob temperatura de congelamento a $-18^{\circ} \mathrm{C}$. $\mathrm{Na}$ reativação, a cultura de manutenção, contendo a suspensão bacteriana congelada, foi transferida para incubadora a $32^{\circ} \mathrm{C}$ por 48 h. Após 0 desenvolvimento da cultura foi retirada uma alíquota de $1,0 \mathrm{~mL}$ e transferida para tubo de ensaio com 9,0 mL de caldo GLT (para os Bacillus) ou MRS (para os Lactobacillus), sendo o tubo incubado a $32^{\circ} \mathrm{C}$ por $48 \mathrm{~h}$. Em seguida, nova transferência foi efetuada nas mesmas condições anteriores. Após a incubação, o conteúdo do tubo de ensaio $(10 \mathrm{~mL})$, foi transferido para erlenmeyer contendo $500 \mathrm{~mL}$ do meio MCC seguido de incubação a $32^{\circ} \mathrm{C}$ por 48 h (Figura 2).

\subsection{Procedimento para obtenção de culturas mistas de bactérias e Saccharomyces cerevisiae}

Os ensaios utilizando culturas mistas de bactéria e $S$. cerevisiae empregaram as culturas de bactérias ativas (ou sem tratamento) e também as culturas de bactérias tratadas pelo calor ou pelo antimicrobiano Kamoran $\mathrm{HJ}$ ou por radiação gama.

Estes ensaios com a cultura bacteriana tratada visaram estudar o efeito dos produtos metabólicos das bactérias sobre a viabilidade da levedura. Os diferentes tratamentos visaram verificar possíveis mudanças no meio e em seus compostos, as quais poderiam afetar a redução da viabilidade da levedura. 


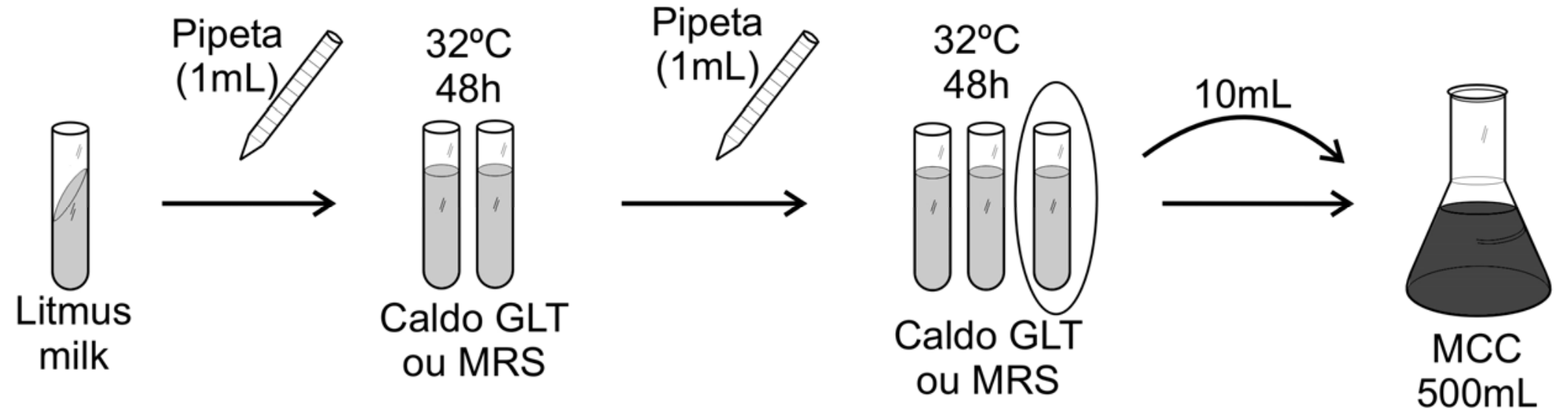

Figura 2 - Esquema do cultivo das bactérias (B. subtilis, B. coagulans, B. stearothermophilus, L. plantarum e L. fermentum) 


\subsubsection{Culturas mistas com bactérias ativas}

A partir dos $500 \mathrm{~mL}$ do meio MCC inoculado com a cultura de bactéria (item 3.3.2.), foram transferidas alíquotas de $50 \mathrm{~mL}$ em 8 frascos erlenmeyer, adicionados de alíquotas de $50 \mathrm{~mL}$ do meio MCC inoculado com a cultura de $S$. cerevisiae (item 3.3.1.). Como controle foram utilizadas alíquotas de $50 \mathrm{~mL}$ do meio MCC inoculado com a cultura da levedura, adicionados de $50 \mathrm{~mL}$ do meio MCC estéril. Todos os frascos (amostras e controles) foram mantidos a $32^{\circ} \mathrm{C}$ por 72 h, em incubador com ambiente controlado New Brunswick com agitação circular de 50 rpm (Figura 3).

\subsubsection{Culturas mistas com bactérias tratadas}

As culturas mistas de leveduras com bactérias tratadas receberam 0 mesmo procedimento de obtenção das culturas mistas de leveduras com bactérias ativas, porém $24 \mathrm{~h}$ antes da mistura dos meios, os meios MCC inoculados com as culturas de bactérias (item 3.3.2.) receberam um dos tratamentos especificados a seguir: calor, agente antimicrobiano e irradiação.

O tratamento por calor foi através de esterilização em autoclave a $121^{\circ} \mathrm{C}$ por 20 minutos. O tratamento por antimicrobiano foi através da aplicação de Kamoran HJ na concentração de 3,0 ppm (Oliveira, et al., 1996; Alcarde, 2000) e incubação por 24 horas a $32^{\circ} \mathrm{C}$. O tratamento por irradiação foi através da radiação gama, com doses de 5,0 kGy para os Lactobacillus e 15,0 kGy para os Bacillus. Estas doses foram escolhidas segundo resultados obtidos por Alcarde (2000), que estudou a inativação de bactérias Bacillus e Lactobacillus em mosto de caldo de cana. A irradiação foi efetuada em irradiador Gammacell 220 Escel MDS Nordion, emissor de radiação gama provenientes do Cobalto-60, instalado 
no Centro de Energia Nuclear na Agricultura, Universidade de São Paulo, em Piracicaba-SP.

Portanto a partir dos $500 \mathrm{~mL}$ do meio MCC inoculado com a cultura de bactérias seguido do tratamento especificado, foram transferidas alíquotas de 50 $\mathrm{mL}$ em 8 frascos erlenmeyer, adicionados de alíquotas de $50 \mathrm{~mL}$ do meio MCC inoculado com a cultura de $S$. cerevisiae. E como controle também foram utilizadas alíquotas de $50 \mathrm{~mL}$ do meio MCC inoculado com a cultura da levedura, adicionados de $50 \mathrm{~mL}$ do meio MCC estéril. Todos os frascos (amostras e controles) novamente foram mantidos a $32^{\circ} \mathrm{C}$ por $72 \mathrm{~h}$, em incubador com ambiente controlado New Brunswick com agitação circular de 50 rpm (Figura 4). 


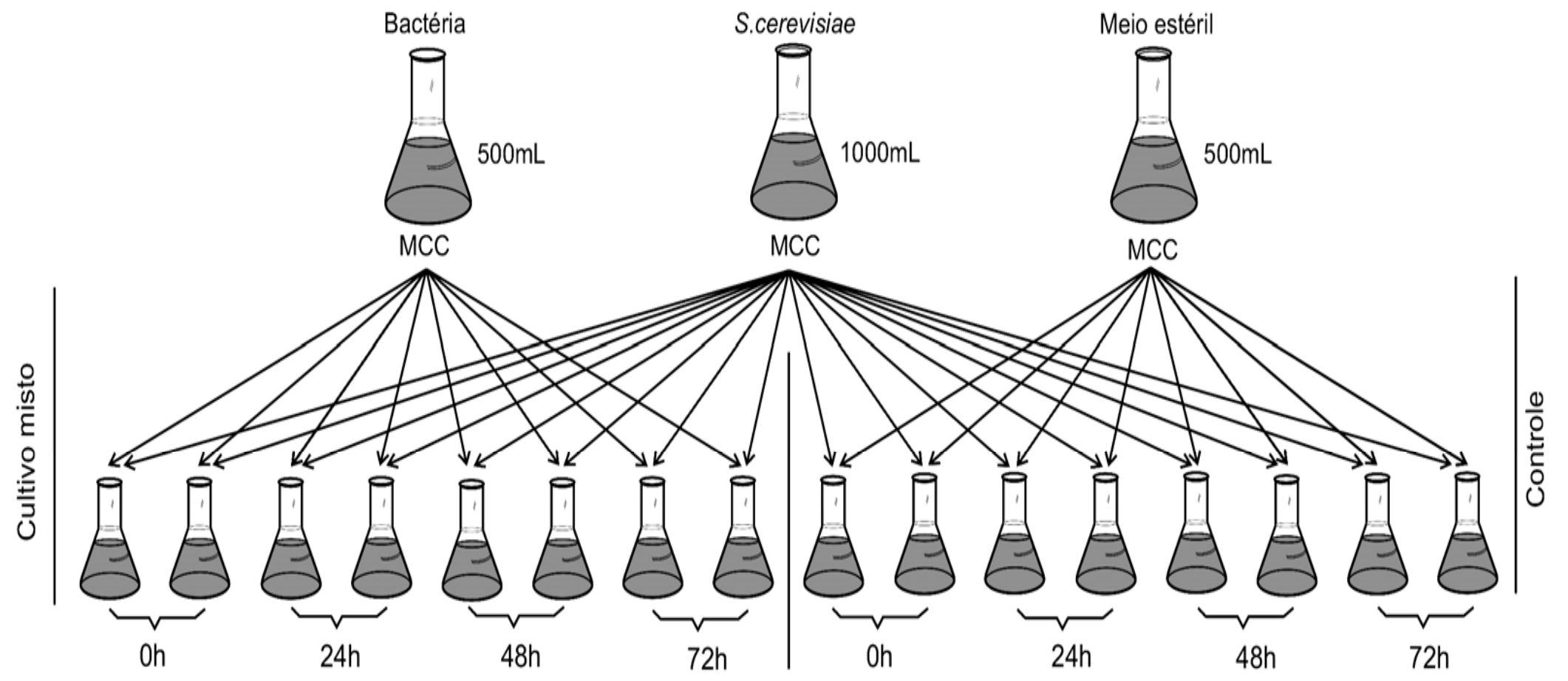

Figura 3 - Procedimento para obtenção de culturas mistas de bactérias ativas e Saccharomyces cerevisiae 


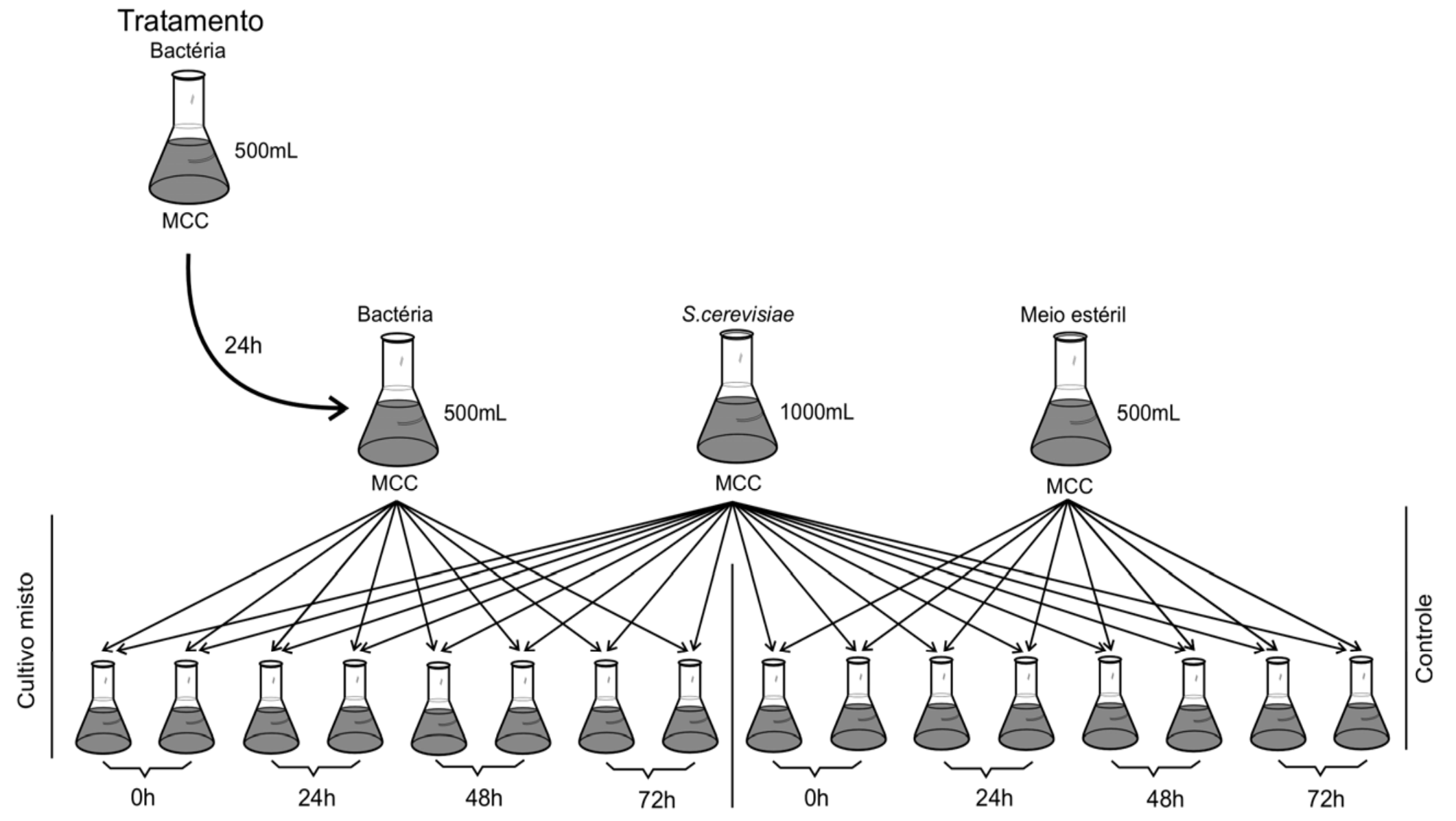

Figura 4 - Procedimento para obtenção de culturas mistas de bactérias tratadas e Saccharomyces cerevisiae 


\subsection{Determinações físico-químicas}

As análises físico-químicas; acidez total, acidez volátil e o $\mathrm{pH}$ do meio, foram determinados às $0,24,48$ e $72 \mathrm{~h}$ do cultivo misto de bactéria (ativa ou tratada) e S. cerevisiae.

\subsubsection{Determinação da acidez total}

A determinação da acidez total do meio foi realizada através da metodologia proposta por Amerine \& Ough (1974), e descrita em Zago et al. (1996), onde $20 \mathrm{~mL}$ da amostra homogeneizada foi transferida para erlenmeyer, adicionado de $50 \mathrm{~mL}$ de água destilada e 2-3 gotas da solução indicadora de fenolftaleína 1\%, e em seguida titulado com hidróxido de sódio $0,05 \mathrm{~N}$ até a mudança de coloração. Através do volume gasto de $\mathrm{NaOH} 0,05 \mathrm{~N}$ obtêve-se a acidez total, e o resultado foi expresso em mg de ácido acético/L.

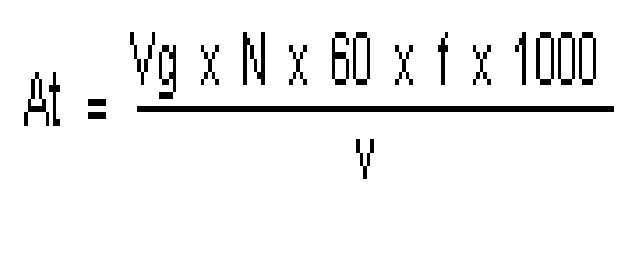

Onde: $A t=$ acidez total (mg de ácido acético/L)

$\mathrm{Vg}=$ volume de solução de $\mathrm{NaOH} 0,05 \mathrm{~N}$ gasto $(\mathrm{mL})$

$\mathrm{N}=$ normalidade da solução de $\mathrm{NaOH}$

60 = equivalente do ácido acético

$f=$ fator de correção do $\mathrm{NaOH} 0,05 \mathrm{~N}$

$\mathrm{v}=$ volume da amostra $(\mathrm{mL})$, neste caso $20 \mathrm{~mL}$. 


\subsubsection{Determinação da acidez volátil}

A determinação da acidez volátil do meio seguiu o procedimento proposto por Amerine \& Ough (1974), onde $10 \mathrm{~mL}$ da amostra foi introduzida na câmara de destilação do Redutec, provido de condensador apropriado para essa técnica; procedeu-se a destilação com o máximo de arraste de vapor até que se obteve um volume de $125 \mathrm{~mL}$ no frasco erlenmeyer contendo, inicialmente, $25 \mathrm{~mL}$ de água destilada; foi adicionado de 2 a 3 gotas da solução indicadora de fenolftaleína 1\%; e titulado, com hidróxido de sódio $0,05 \mathrm{~N}$, até a mudança de coloração, anotando o volume gasto.

O fator $F$ de padronização foi obtido da mesma forma descrita anteriormente, porém a amostra $(10 \mathrm{~mL})$ destilada foi uma solução padrão de ácido acético (1,2g/L).

Como na acidez total, também através do volume gasto de $\mathrm{NaOH} \mathrm{0,05N}$ calcula-se a acidez volátil, e o resultado foi expresso em mg de ácido acético/L.

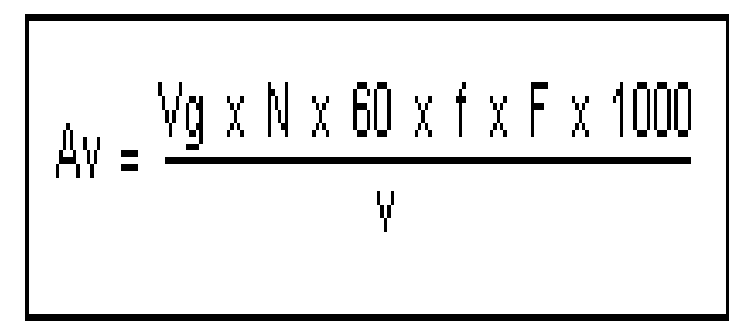

Onde: $\mathrm{Av}$ = acidez volátil (mg de ácido acético/L)

$\mathrm{Vg}=$ volume de solução de $\mathrm{NaOH} 0,05 \mathrm{~N}$ gasto $(\mathrm{mL})$

$\mathrm{N}=$ normalidade da solução de $\mathrm{NaOH}$

60 = equivalente do ácido acético

$f=$ fator de correção do $\mathrm{NaOH} 0,05 \mathrm{~N}$

$\mathrm{v}=$ volume da amostra $(\mathrm{mL})$

$\mathrm{F}=$ fator de padronização da metodologia $(F=4,00 / \mathrm{Vg})$ 


\subsubsection{Determinação do pH}

A determinação do $\mathrm{pH}$ foi efetuada através da utilização de potenciômetro modelo DMPH-1, marca Digimed, seguindo a metodologia proposta por Pregnolato e Pregnolato (1985).

\subsection{Determinações microbiológicas}

As análises microbiológicas: viabilidade celular, o brotamento e a população de células da levedura S. cerevisiae, foram determinados às 0, 24, 48 e $72 \mathrm{~h}$ do cultivo misto de bactéria (ativa ou tratada) e $S$. cerevisiae. Os plaqueamentos das bactérias e da levedura, foram realizados às 0 , e $72 \mathrm{~h}$ dos cultivos mistos de bactérias (ativas ou tratadas) e S. cerevisiae.

\subsubsection{Viabilidade celular, brotamento e população de células da levedura $S$. cerevisiae}

A viabilidade celular, o brotamento e a população de células da levedura $S$. cerevisiae foram determinados através da coloração diferencial das células pela solução de eritrosina e posterior contagem das células viáveis, não viáveis e dos brotos viáveis presentes em 160 retículos da câmara de Neubauer espelhada, através de microscopia ótica, em microscópio OLYMPUS, modelo $\mathrm{BH}$, em aumento de 400x, de acordo com a metodologia descrita por Oliveira et al. (1996).

$\mathrm{Na}$ coloração diferencial da solução de eritrosina, em tampão fosfato, as células viáveis permanecem incolores, enquanto as não viáveis são coradas de rósea intensa.

Os resultados são expressos em porcentagem, sendo que a viabilidade representa a relação entre células vivas e total de células, o brotamento corresponde à relação entre brotos vivos e total de células, e o número de células 
viáveis ou a população de células da levedura $S$. cerevisiae foi calculada estabelecendo-se uma relação entre células vivas, volume da câmara e total de retículos contados.

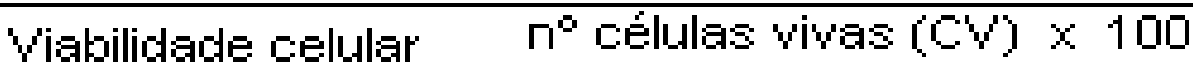

$$
\begin{aligned}
& \text { (\% cêlulas wivas) = }{ }^{\circ} \text { de células contadas }
\end{aligned}
$$

$$
\begin{aligned}
& \text { Taxa de } \quad \text { o brotos } \times 100
\end{aligned}
$$

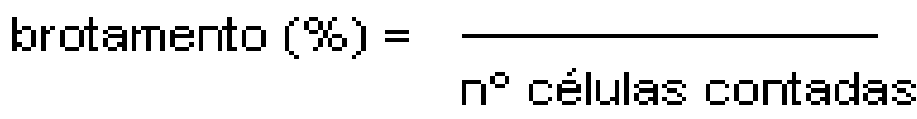

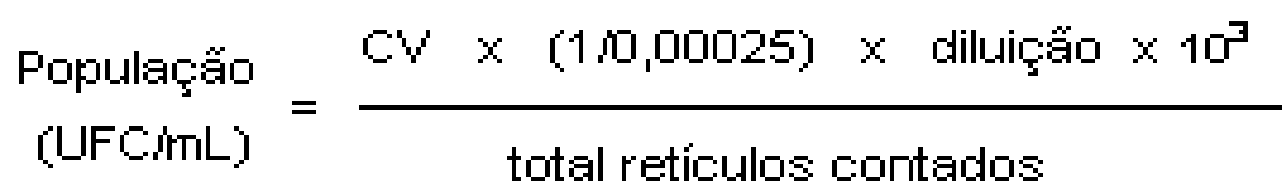

\subsubsection{Plaqueamentos dos microrganismos}

A semeadura em placas para contagem das unidades formadoras de colônia por $\mathrm{mL}$ (UFC/mL) dos microrganismos foi realizada através da técnica de plaqueamento em profundidade ("pour plate"), utilizando os meios de cultivo convencionais (PCA para os Bacillus, MRS-agar para os Lactobacillus e YEPDagar para a levedura S. cerevisiae) e o meio de cultivo MCC-agar (para todos os microrganismos), quando em culturas mistas de leveduras e bactérias ativas.

Nas culturas mistas de leveduras e bactérias tratadas, as ações dos tratamentos foram avaliadas para cada espécie de bactéria através de plaqueamentos, em meios de cultivos convencionais, prévio e após 24 horas de aplicação. Ainda assim, foram realizados plaqueamentos, em meios de cultivos 
convencionais, às 0 e 72 horas dos períodos de cultivos mistos para confirmação ou não da sobrevivência das bactérias durante o ensaio. Os plaqueamentos foram realizados com meios de cultivos convencionais (PCA para as bactérias do gênero Bacillus e MRS-agar para as bactérias do gênero Lactobacillus).

Os plaqueamentos seguiram os procedimentos descritos por Oliveira et al. (1996), sendo que para as diluições seriadas foram utilizados tubos de ensaio com $9,0 \mathrm{~mL}$ de água peptonada $(0,1 \%)$ esterilizada. As placas foram incubadas a $32^{\circ} \mathrm{C}$ por 24-48 h para crescimento e posterior contagem das colônias. E nos meios de cultivos foi adicionado actidiona na concentração de 10 ppm, como inibidor da levedura, quando o objetivo foi contagem das colônias de bactérias.

\subsection{Análise estatística}

Os ensaios dos cultivos mistos foram realizados em um delineamento experimental inteiramente casualizado no esquema fatorial $4 \times 6$ (4 períodos $\times 6$ microrganismos). As análises estatísticas dos dados foram realizadas no programa SAS - Statistical Analysis System (SAS Institute, 1990) utilizando o procedimento GLM. Foram realizadas as análises de variância e como a interação período $\mathrm{x}$ microrganismo foi significativa, foram realizados os desdobramentos das análises com aplicação do Teste de Tukey. 


\section{RESULTADOS E DISCUSSÃO}

Os resultados das determinações físico-químicas e microbiológicas de todos os cultivos mistos de bactérias e leveduras, média de duas repetições por ensaio, encontram-se nas Tabelas de 32 a 40 do Apêndice.

As Tabelas de 41 a 52 apresentam as médias gerais de cada variável, seguido do $R^{2}$, coeficiente de variação e desvio padrão das mesmas e os quadrados médio das análises de variância seguido da significância do Teste $\mathrm{F}$ dos fatores Microrganismo (Micro), Período (Per) e Interação (Micro * Per) para cada tratamento.

\subsection{Cultivos mistos de S. cerevisiae e bactérias ativas}

As contagens bacteriológicas (UFC/mL), apresentadas na Tabela 1, confirmam a sobrevivência das bactérias durante o ensaio, envolvendo $S$. cerevisiae. Os plaqueamentos foram realizados com meios de cultivos convencionais (PCA para os Bacillus e MRS-agar os Lactobacillus).

Em alguns casos a população bacteriana pouco aumenta em $72 \mathrm{~h}$ de cultivo e, em um caso, chega até a diminuir ou quase que manter a contagem da população inicial. Mas o importante a ser notado com a contagem bacteriana é que, durante o cultivo misto, a bactéria, seja qual for, apresenta-se com uma população considerada por Amorim et al. (1981), Alterthum et al. (1984), Khan \& 
Hoq (1990) prejudicial ao rendimento da fermentação e à viabilidade celular da levedura.

Tabela 1. Contagem bacteriana inicial e final dos cultivos mistos de bactérias ativas e leveduras

\begin{tabular}{lcc}
\hline & CONTAGEM BACTERIANA (UFC/mL)* \\
\hline Bactéria & Inicial $(0 \mathrm{~h})^{\star}$ & Final $(72 \mathrm{~h})^{\star}$ \\
\hline B. stearothermophilus & $6,7 \times 10^{8}$ & $3,4 \times 10^{8}$ \\
B. coagulans & $1,2 \times 10^{7}$ & $8,4 \times 10^{7}$ \\
B. subtilis & $4,8 \times 10^{7}$ & $7,7 \times 10^{8}$ \\
L. fermentum & $8,6 \times 10^{6}$ & $1,0 \times 10^{7}$ \\
L. plantarum & $2,8 \times 10^{6}$ & $6,3 \times 10^{6}$ \\
\hline
\end{tabular}

* Média de 18 plaqueamentos

* Inicial $(0 \mathrm{~h})$ = início do período de incubação das culturas mistas de bactérias ativas e leveduras

* Final $(72 \mathrm{~h})=$ final do período de cultivo misto

De modo geral, a acidez total (Figura 5A) e a acidez volátil (Figura 5B) dos meios de cultivos inoculados ou não, com as diferentes bactérias ativas, aumentaram nas 24 horas iniciais do cultivo, vindo posteriormente a diminuir até as 72 horas, termino do cultivo. Consequentemente o $\mathrm{pH}$ (Figura $5 \mathrm{C}$ ) desses meios apresentou tendência inversa, isto é, diminuiu até $24 \mathrm{~h}$ e, em seguida, aumentou até $72 \mathrm{~h}$ dos cultivos mistos de bactérias e leveduras e do cultivo isolado das leveduras. 

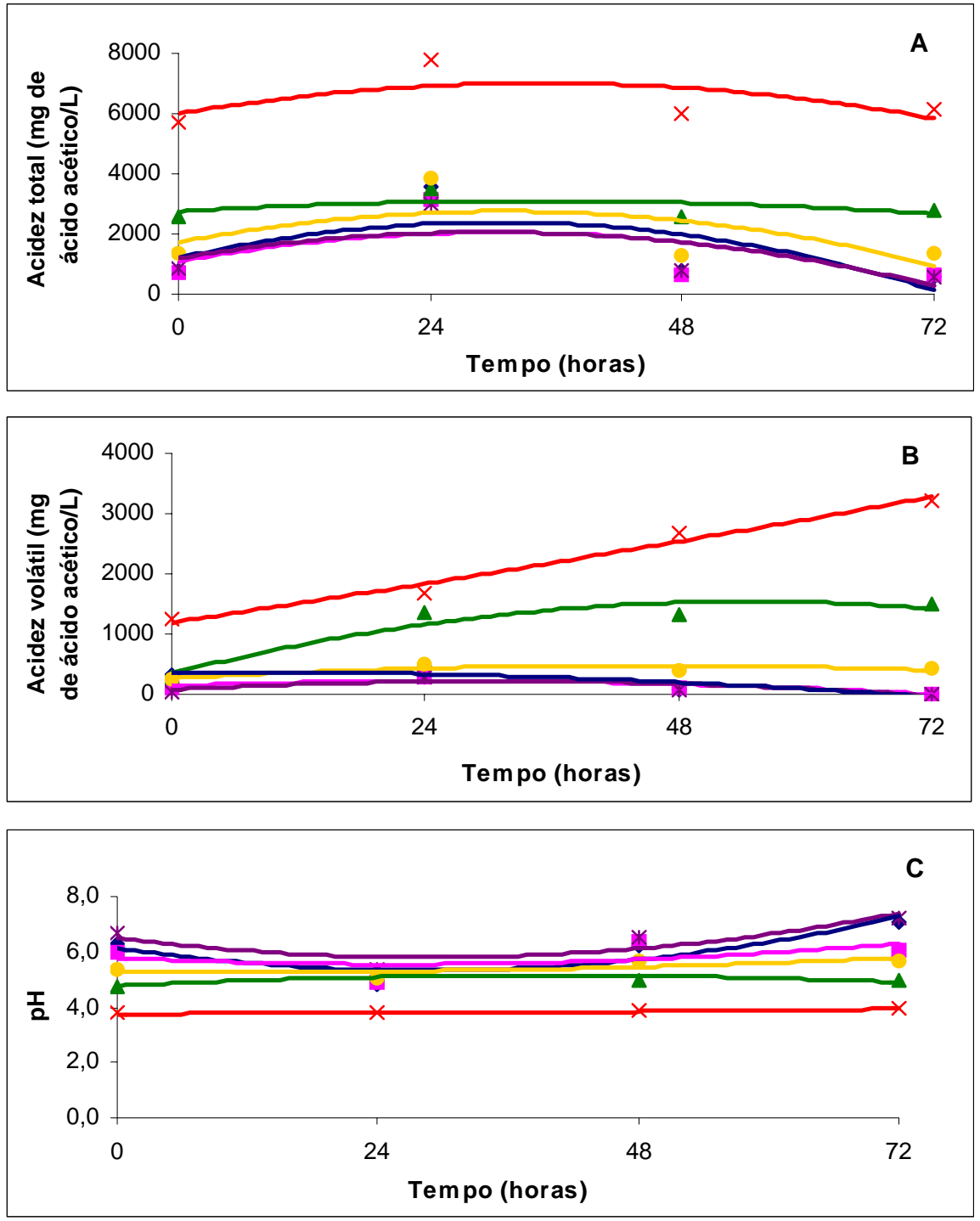

Figura 5 - Variações das determinações físico-químicas: acidez total (A), acidez volátil (B) e pH (C); durante o cultivo misto de $S$. cerevisia com as bactérias ativas: $B$. stearothermophilus $(\triangleleft), B$. coagulans $(\square)$, B. subtilis $(\bullet)$, L. fermentum $(\mathbf{x}), L$. plantarum (*); e o controle $(\odot)$ refere-se de $S$. cerevisiae cultivada sem a presença de bactérias 
A acidificação, observada através da acidez total (Tabela 2), após 24 horas de incubação, apresenta diferença significativa em relação aos demais períodos $(0,48$ e $72 \mathrm{~h})$, em todos os meios de cultivos, inoculados ou não, com as diferentes bactérias ativas.

Os valores de acidez total e volátil dos cultivos mistos de $S$. cerevisiae com B. stearothermophilus ou B. coagulans ou L. plantarum, apesar de apresentaremse ligeiramente menores em todos os períodos, não diferiram estatisticamente do controle (Tabela 2 e 3). Nestes casos, como os valores de acidez total e volátil desde o início são semelhantes ao controle, deduz-se que os ácidos possam, provavelmente, ter sido produzidos quase que exclusivamente por S. cerevisiae.

Ao contrário dos outros cultivos mistos, $L$. fermentum e B. subtilis, apresentaram valores de acidez total e volátil superiores ao controle durante todo o ensaio e diferiram estatisticamente do controle (Tabela 2 e 3). Destacam-se os valores de acidez total e volátil do cultivo misto de $S$. cerevisiae e $L$. fermentum em todos os períodos, sugerindo que, nestas condições de cultivo, esta bactéria foi a mais eficiente produtora de ácidos orgânicos.

Diferente do comportamento da acidez total, os valores de acidez volátil nos cultivos mistos de $S$. cerevisiae com $B$. stearothermophilus ou B. coagulans ou L. plantarum, incluindo o controle, não variaram estatisticamente entre os períodos, mantendo-se constantes do início até o fim do cultivo (Tabela 3). 
Tabela 2. Teste de Tukey para as médias de acidez total comparando os microrganismos e os períodos, em cultura mista de $S$. cerevisiae e bactérias ativas

\begin{tabular}{c|c|c|c|c|c|c}
\hline \multirow{2}{*}{$\begin{array}{c}\text { Períodos } \\
\text { (horas) }\end{array}$} & \begin{tabular}{c} 
Cultivo misto de S. cerevisiae com \\
Bacillus \\
\cline { 2 - 6 }
\end{tabular} & $\begin{array}{c}\text { Bacillus } \\
\text { subtilis }\end{array}$ & $\begin{array}{c}\text { Bacillus } \\
\text { coagulans }\end{array}$ & $\begin{array}{c}\text { Lactobac. } \\
\text { plantarum }\end{array}$ & $\begin{array}{c}\text { Lactobac. } \\
\text { fermentum }\end{array}$ & (controle) \\
\cline { 2 - 6 } & \multicolumn{6}{|c|}{ Acidez Total (mg ácido acético / L) } \\
\hline 0 & $790 \mathrm{Aa}$ & $2595 \mathrm{Ab}$ & $720 \mathrm{Aa}$ & $880 \mathrm{Aa}$ & $5715 \mathrm{Ac}$ & $1345 \mathrm{Aa}$ \\
\hline 24 & $3555 \mathrm{Ba}$ & $3520 \mathrm{Ba}$ & $3116 \mathrm{Ba}$ & $2975 \mathrm{Ba}$ & $7765 \mathrm{Bb}$ & $3844 \mathrm{Ba}$ \\
\hline 48 & $770 \mathrm{Aa}$ & $2590 \mathrm{Ab}$ & $656 \mathrm{Aa}$ & $780 \mathrm{Aa}$ & $6013 \mathrm{Ac}$ & $1305 \mathrm{Aa}$ \\
\hline 72 & $545 \mathrm{Aa}$ & $2810 \mathrm{Ab}$ & $635 \mathrm{Aa}$ & $595 \mathrm{Aa}$ & $6120 \mathrm{Ac}$ & $1334 \mathrm{Aa}$ \\
\hline
\end{tabular}

Obs.: Médias seguidas pelas mesmas letras, minúsculas nas linhas e maiúsculas nas colunas, não diferem entre si de acordo com o teste de Tukey ao nível de 1 \% de significância

Tabela 3. Teste de Tukey para as médias de acidez volátil comparando os microrganismos e os períodos, em cultura mista de S. cerevisiae e bactérias ativas

\begin{tabular}{|c|c|c|c|c|c|c|}
\hline \multirow{3}{*}{$\begin{array}{c}\text { Períodos } \\
\text { (horas) }\end{array}$} & \multicolumn{5}{|c|}{ Cultivo misto de S. cerevisiae com } & \multirow{2}{*}{$\begin{array}{l}\text { S. cerevisiae } \\
\text { (controle) }\end{array}$} \\
\hline & $\begin{array}{c}\text { Bacillus } \\
\text { stearothermophilus }\end{array}$ & $\begin{array}{l}\text { Bacillus } \\
\text { subtilis }\end{array}$ & $\begin{array}{c}\text { Bacillus } \\
\text { coagulans }\end{array}$ & $\begin{array}{l}\text { Lactobac. } \\
\text { plantarum }\end{array}$ & $\begin{array}{l}\text { Lactobac. } \\
\text { fermentum }\end{array}$ & \\
\hline & \multicolumn{6}{|c|}{ Acidez Volátil (mg ácido acético / L) } \\
\hline 0 & $320 \mathrm{Aa}$ & $280 \mathrm{Aa}$ & $120 \mathrm{Aa}$ & $48 \mathrm{Aa}$ & $1239 \mathrm{Ab}$ & $244 \mathrm{Aa}$ \\
\hline 24 & $475 \mathrm{Aa}$ & $1350 \mathrm{Bb}$ & $275 \mathrm{Aa}$ & $306 \mathrm{Aa}$ & $1694 \mathrm{Ab}$ & $504 \mathrm{Aa}$ \\
\hline 48 & $64 \mathrm{Aa}$ & $1335 \mathrm{Bb}$ & $115 \mathrm{Aa}$ & $85 \mathrm{Aa}$ & $2682 \mathrm{Bc}$ & $406 \mathrm{Aa}$ \\
\hline 72 & $28 \mathrm{Aa}$ & $1485 \mathrm{Bb}$ & $41 \mathrm{Aa}$ & $15 \mathrm{Aa}$ & $3231 \mathrm{Cc}$ & $424 \mathrm{Aa}$ \\
\hline
\end{tabular}

Obs.: Médias seguidas pelas mesmas letras, minúsculas nas linhas e maiúsculas nas colunas, não diferem entre si de acordo com o teste de Tukey ao nível de 1 \% de significância

Tabela 4. Teste de Tukey para as médias de $\mathbf{p H}$, comparando os microrganismos e os períodos, em cultura mista de S. cerevisiae e bactérias ativas

\begin{tabular}{c|c|c|c|c|c|c}
\hline \multirow{2}{*}{$\begin{array}{c}\text { Períodos } \\
\text { (horas) }\end{array}$} & \multicolumn{5}{|c|}{ Cultivo misto de S. cerevisiae com } & \multirow{2}{*}{$\begin{array}{c}\text { S. cerevisiae } \\
\text { (controle) }\end{array}$} \\
\cline { 2 - 6 } & $\begin{array}{c}\text { Bacillus } \\
\text { stearothermophilus }\end{array}$ & $\begin{array}{c}\text { Bacillus } \\
\text { subtilis }\end{array}$ & $\begin{array}{c}\text { Bacillus } \\
\text { coagulans }\end{array}$ & $\begin{array}{c}\text { Lactobac. } \\
\text { plantarum }\end{array}$ & $\begin{array}{c}\text { Lactobac. } \\
\text { fermentum }\end{array}$ & \\
\cline { 2 - 6 } & \multicolumn{6}{|c|}{$\mathrm{pH}$} \\
\hline 0 & $6,31 \mathrm{Aac}$ & $4,73 \mathrm{Ab}$ & $6,00 \mathrm{Aa}$ & $6,65 \mathrm{Ac}$ & $3,77 \mathrm{Ad}$ & $5,39 \mathrm{Abe}$ \\
\hline 24 & $4,85 \mathrm{Ba}$ & $4,89 \mathrm{Aa}$ & $4,89 \mathrm{Ba}$ & $5,37 \mathrm{Ba}$ & $3,77 \mathrm{Ab}$ & $5,06 \mathrm{Aa}$ \\
\hline 48 & $6,22 \mathrm{Aac}$ & $5,00 \mathrm{Ab}$ & $6,38 \mathrm{Aa}$ & $6,56 \mathrm{Aa}$ & $3,86 \mathrm{Ad}$ & $5,69 \mathrm{Bc}$ \\
\hline 72 & $7,10 \mathrm{Cb}$ & $4,94 \mathrm{Ac}$ & $6,08 \mathrm{Aa}$ & $7,25 \mathrm{Cb}$ & $3,93 \mathrm{Ad}$ & $5,70 \mathrm{Ba}$ \\
\hline
\end{tabular}

Obs.: Médias seguidas pelas mesmas letras, minúsculas nas linhas e maiúsculas nas colunas, não diferem entre si de acordo com o teste de Tukey ao nível de 1 \% de significância 
Diferente da acidez total e volátil, $\mathrm{o} \mathrm{pH}$ do meio no cultivo de $S$. cerevisiae com B. subtilis ou $L$. fermentum, Tabela 4, manteve-se constante em todos os períodos e apresentaram os menores valores entre todos os microrganismos estudados.

As bactérias $L$. fermentum e $B$. subtilis se destacaram na produção de ácidos, pois os meios inoculados com estas bactérias ativas apresentaram as maiores concentrações de acidez total e volátil (Figuras 5A e 5B). Conseqüentemente os meios inoculados com estas duas bactérias ativas apresentaram os menores valores de $\mathrm{pH}$ ao longo do período de incubação com S. cerevisiae (Figura 5C).

O comportamento do $\mathrm{pH}$ foi semelhante, nos cultivos mistos de $S$. cerevisiae com B. stearothermophilus ou B. coagulans ou L. plantarum (Tabela 4). O período de $24 \mathrm{~h}$ se destaca entre os demais, pois há uma acidificação do meio e uma diminuição do $\mathrm{pH}$, e é o único período em que todos estes cultivos se igualam estatisticamente ao controle; nos outros períodos, em sua maior parte, os valores de $\mathrm{pH}$ diferem estatisticamente do controle por apresentarem altos valores que atingiram acima de 7 no fim dos períodos contra apenas 5,7 do controle (Figura 5C).

Antes de serem misturadas para os cultivos mistos, $S$. cerevisiae e as bactérias foram inicialmente crescidas em meios separados. Como as bactérias testadas não possuem a capacidade de metabolizar sacarose, quando os meios com S. cerevisiae e as bactérias foram misturados, S. cerevisiae voltou a estar em um meio rico em açúcar. Assim, enquanto havia açúcar disponível, $S$. cerevisiae realizou fermentação alcoólica, com conseqüente aumento da acidez do meio devido à produção de ácidos orgânicos, um dos produtos secundários do processo de catabolismo do substrato. Esta foi a razão do aumento da acidez total e volátil dos meios de cultivos nas primeiras 24 horas do período de incubação das culturas de $S$. cerevisiae e bactérias. 
Segundo Alves (2000), linhagens de leveduras produzem ácido succínico e ácido málico durante a fermentação, e mesmo que estes ácidos venham a ser reabsorvidos, contribuem para a acidificação do meio.

A acidez dos meios de cultivos diminuiu após $24 \mathrm{~h}$ do período de incubação porque quando se esgotam os açúcares do meio $S$. cerevisiae cessa a fermentação alcoólica e passa a absorver $\mathrm{H}^{+}$do meio externo e liberar $\mathrm{K}+$ celular ao meio (Conway \& Downey, 1950; Gomes, 1988; Rothstein \& Bruce, 1958; Seaston et al., 1976). Assim, o pH interno das células de $S$. cerevisiae se reduz e o pH do meio externo aumenta, provocando redução de acidez do meio.

A redução do $\mathrm{pH}$ interno da célula de $\mathrm{S}$. cerevisiae, decorrente da maior absorção de $\mathrm{H}+$, está relacionada com menores teores endógenos de $\mathrm{P}$ e $\mathrm{N}$ e dos carboidratos de reserva, trealose e glicogênio (Gomes, 1988). Quanto à redução do conteúdo endógeno de glicogênio, a redução do $\mathrm{pH}$ interno das células reflete na síntese de ATP e, em adição, a liberação de $\mathrm{K}+$ em troca de $\mathrm{H}+$ provoca um consumo substancial de energia para a manutenção do gradiente transmembrânico de K+ nas células (Páca, 1981). Assim, para evitar uma deficiência energética, as células consomem glicogênio para a ativação do metabolismo endógeno visando fornecer a energia requerida para a manutenção celular.

Chester (1959) foi o primeiro autor a demonstrar que, sob aerobiose ou anaerobiose, linhagens de S. cerevisiae degradam, por fermentação endógena, suas reservas de carboidratos durante a ausência de nutrientes. Como resultado dessa fermentação, observou-se uma redução de $50 \%$ no conteúdo total dos carboidratos de reserva glicogênio e trealose, após um período de 5 horas de ausência de açúcar no meio.

Além das células de leveduras consumirem os carboidratos de reserva, glicogênio e trealose, Sols et al. (1971), descreveram ainda outras formas de produção de energia pelo metabolismo das leveduras na ausência de açúcar no 
meio, como a assimilação de etanol e ácidos láctico, pirúvico, succínico e málico, visando fornecer a energia requerida para a manutenção celular.

Casal et al. (1996), observaram que S. cerevisiae sob certas condições produziam traços de ácido acético e podiam utilizá-lo como fonte de carbono se o $\mathrm{pH}$ do meio estivesse por volta de 5 ou mais.

Estudando o efeito de lactobacilos em cultura mista com leveduras, Thomas et al (2001), observaram que após alcançar um valor máximo, o conteúdo de ácido láctico começa a declinar, indicando provavelmente que foi utilizado pelas leveduras. Os autores também observaram que o início da redução do ácido láctico coincide com a exaustão dos açúcares do meio.

As análises do perfil de acúmulo de biomassa, produção de etanol e consumo de açúcar, realizadas por Cruz (2002), mostraram que em baixas concentrações de glicose observa-se claramente a diauxia, onde inicialmente a levedura utiliza glicose para produzir etanol e biomassa e após a exaustão da glicose, o etanol é utilizado como fonte de carbono.

De modo geral, a viabilidade celular de $S$. cerevisiae (Figura $6 A$ ) foi afetada apenas no cultivo misto com $L$. fermentum e B. subtilis. A taxa de brotamento de S. cerevisiae (Figura 6B) diminuiu ao longo do cultivo misto de todas as bactérias; e a população de células de S. cerevisiae (Figura 6C) apresentou-se sempre ligeiramente abaixo do controle. 

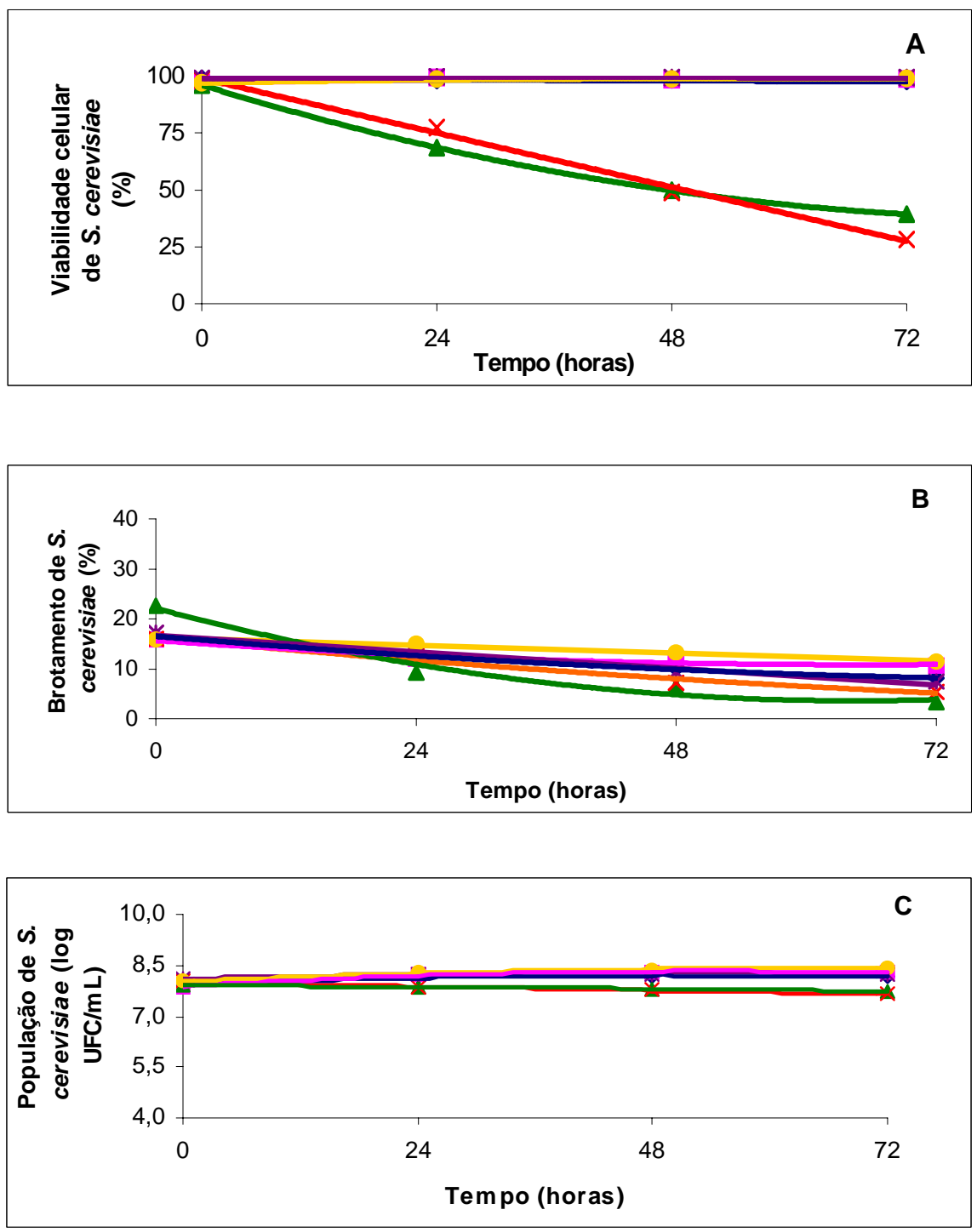

Figura 6 - Variações das determinações microbiológicas: viabilidade celular (A), taxa de brotamento (B) e população de células (C) de $S$. cerevisiae; durante o cultivo misto de $S$. cerevisia com as bactérias ativas: $B$. stearothermophilus $(\diamond), B$. coagulans $(\square)$, B. subtilis $(\bullet)$, L. fermentum $(\boldsymbol{X})$, L. plantarum $(*)$; e o controle $(\circlearrowleft)$ refere-se de $S$. cerevisiae cultivada sem a presença de bactérias 
A viabilidade celular de S. cerevisiae foi afetada apenas no cultivo misto com $L$. fermentum e B. subtilis, as quais diminuíram significativamente a porcentagem de células vivas de $S$. cerevisiae ao longo do período de cultivo (Figura 6A, Tabela 5). O cultivo misto de $S$. cerevisiae e B. subtilis reduziu em $59,2 \%$ a viabilidade da levedura, enquanto o cultivo misto com L. fermentum reduziu em 73,5 \% a viabilidade celular da levedura.

As demais bactérias, $B$. stearothermophilus ou $B$. coagulans ou $L$. plantarum, não influenciaram a viabilidade celular de $S$. cerevisiae, pois nos cultivos associados de $S$. cerevisiae com estas bactérias, a porcentagem de células vivas de $S$. cerevisiae ao longo do período de incubação foi semelhante e não apresentou diferença estatística (Figura 6A, Tabela 5) em relação à viabilidade celular de $S$. cerevisiae no cultivo controle.

Tabela 5. Teste de Tukey para as médias de viabilidade celular de $\mathbf{S}$. cerevisiae, comparando os microrganismos e os períodos, em cultura mista de $S$. cerevisiae e bactérias ativas

\begin{tabular}{|c|c|c|c|c|c|c|}
\hline \multirow{3}{*}{$\begin{array}{c}\text { Períodos } \\
\text { (horas) }\end{array}$} & \multicolumn{5}{|c|}{ Cultivo misto de S. cerevisiae com } & \multirow{2}{*}{$\begin{array}{l}\text { S. cerevisiae } \\
\text { (controle) }\end{array}$} \\
\hline & $\begin{array}{c}\text { Bacillus } \\
\text { stearothermophilus }\end{array}$ & $\begin{array}{l}\text { Bacillus } \\
\text { subtilis }\end{array}$ & $\begin{array}{c}\text { Bacillus } \\
\text { coagulans }\end{array}$ & $\begin{array}{l}\text { Lactobac. } \\
\text { Plantarum }\end{array}$ & $\begin{array}{l}\text { Lactobac. } \\
\text { fermentum }\end{array}$ & \\
\hline & \multicolumn{6}{|c|}{ Viabilidade celular de S. cerevisiae (\%) } \\
\hline 0 & $99,05 \mathrm{Ab}$ & $96,05 \mathrm{Ac}$ & $97,00 \mathrm{Aac}$ & $99,00 \mathrm{Ab}$ & $98,14 \mathrm{Aab}$ & 97,08 Aac \\
\hline 24 & $97,87 \mathrm{Aa}$ & $68,40 \mathrm{Bc}$ & $99,30 \mathrm{Ba}$ & $99,24 \mathrm{Aa}$ & $77,30 \mathrm{Bb}$ & $98,34 \mathrm{ABa}$ \\
\hline 48 & 98,37 Aa & $49,32 \mathrm{Cb}$ & $98,20 \mathrm{Aa}$ & $98,60 \mathrm{Aa}$ & $48,90 \mathrm{Cb}$ & $98,80 \mathrm{ABa}$ \\
\hline 72 & $97,60 \mathrm{Aa}$ & $39,20 \mathrm{Dc}$ & $98,80 \mathrm{Aa}$ & $98,97 \mathrm{Aa}$ & $26,00 \mathrm{Db}$ & $99,10 \mathrm{Ba}$ \\
\hline
\end{tabular}

Obs.: Médias seguidas pelas mesmas letras, minúsculas nas linhas e maiúsculas nas colunas, não diferem entre si de acordo com o teste de Tukey ao nível de $1 \%$ de significância

A maioria das bactérias ativas afetou o brotamento de $S$. cerevisiae, pois, ao longo do período de cultivo misto a porcentagem de brotos de $S$. cerevisiae foi menor que no controle (Figura 6B, Tabela 6). No entanto, as bactérias ativas que, em cultivo misto com $S$. cerevisiae, mais reduziram a taxa de brotamento foram, novamente, $L$. fermentum e B. subtilis. 
Observando-se a Tabela 6 , verifica-se que $B$. stearothermophilus, $B$. subtilis, L. plantarum e L. fermentum diferem do controle (S. cerevisiae) e $B$. coagulans, pois a taxa de brotamento em ambos revela queda possivelmente por falta de substrato enquanto as demais bactérias demonstram a probabilidade de haver outros fatores reduzindo a taxa de brotamento além da exaustão de nutrientes.

A população de células de $S$. cerevisiae foi significativamente afetada pelas bactérias ativas $L$. fermentum e $B$. subtilis, as quais diminuíram a densidade populacional de S. cerevisiae ao longo do período de cultivo misto (Figura 6C, Tabela 7). As demais bactérias também influenciaram significativamente a população de $S$. cerevisiae, apesar de nos cultivos associados com as bactérias, a densidade populacional de S. cerevisiae ao longo do período de incubação apresentar-se apenas ligeiramente inferior à densidade populacional de S. cerevisiae no cultivo controle.

Tabela 6. Teste de Tukey para as médias de taxa de brotamento de $\mathbf{S}$. cerevisiae, comparando os microrganismos e os períodos, em cultura mista de $S$. cerevisiae e bactérias ativas

\begin{tabular}{|c|c|c|c|c|c|c|}
\hline \multirow{3}{*}{$\begin{array}{c}\text { Períodos } \\
\text { (horas) }\end{array}$} & \multicolumn{5}{|c|}{ Cultivo misto de S. cerevisiae com } & \multirow{2}{*}{$\begin{array}{l}\text { S. cerevisiae } \\
\text { (controle) }\end{array}$} \\
\hline & $\begin{array}{c}\text { Bacillus } \\
\text { stearothermophilus }\end{array}$ & $\begin{array}{l}\text { Bacillus } \\
\text { subtilis }\end{array}$ & $\begin{array}{c}\text { Bacillus } \\
\text { coagulans }\end{array}$ & $\begin{array}{l}\text { Lactobac. } \\
\text { Plantarum }\end{array}$ & $\begin{array}{l}\text { Lactobac. } \\
\text { fermentum }\end{array}$ & \\
\hline & \multicolumn{6}{|c|}{ Taxa de brotamento de S. cerevisiae (\%) } \\
\hline 0 & $16,64 \mathrm{Aab}$ & $22,60 \mathrm{Ac}$ & $15,94 \mathrm{Aa}$ & $17,14 \mathrm{Ab}$ & $15,97 \mathrm{Aa}$ & $15,90 \mathrm{Aa}$ \\
\hline 24 & $12,34 \mathrm{Ba}$ & $9,30 \mathrm{Bc}$ & $12,00 \mathrm{Ba}$ & $12,90 \mathrm{Ba}$ & $12,50 \mathrm{Ba}$ & $15,10 \mathrm{Ab}$ \\
\hline 48 & $10,14 \mathrm{Cb}$ & $6,40 \mathrm{Cc}$ & $11,97 \mathrm{BCa}$ & $9,40 \mathrm{Cb}$ & $7,20 \mathrm{Cb}$ & $13,30 \mathrm{Bd}$ \\
\hline 72 & $8,14 \mathrm{Db}$ & $3,30 \mathrm{Dd}$ & $10,60 \mathrm{Ca}$ & $7,37 \mathrm{Db}$ & $5,44 \mathrm{Db}$ & $11,34 \mathrm{Ca}$ \\
\hline
\end{tabular}

Obs.: Médias seguidas pelas mesmas letras, minúsculas nas linhas e maiúsculas nas colunas, não diferem entre si de acordo com o teste de Tukey ao nível de $1 \%$ de significância 
Tabela 7. Teste de Tukey para as médias de População de células de $\mathbf{S}$. cerevisiae, comparando os microrganismos e os períodos, em cultura mista de $S$. cerevisiae e bactérias ativas

\begin{tabular}{|c|c|c|c|c|c|c|}
\hline \multirow{3}{*}{$\begin{array}{l}\text { Períodos } \\
\text { (horas) }\end{array}$} & \multicolumn{5}{|c|}{ Cultivo misto de S. cerevisiae com } & \multirow{2}{*}{$\begin{array}{l}\text { S. cerevisiae } \\
\text { (controle) }\end{array}$} \\
\hline & $\begin{array}{c}\text { Bacillus } \\
\text { stearothermophilus }\end{array}$ & $\begin{array}{l}\text { Bacillus } \\
\text { subtilis }\end{array}$ & $\begin{array}{c}\text { Bacillus } \\
\text { coagulans }\end{array}$ & $\begin{array}{l}\text { Lactobac. } \\
\text { Plantarum }\end{array}$ & $\begin{array}{l}\text { Lactobac. } \\
\text { fermentum }\end{array}$ & \\
\hline & \multicolumn{6}{|c|}{ População de células de S. cerevisiae (log UFC/mL) } \\
\hline$\overline{0}$ & $7,915 \mathrm{Ab}$ & $7,893 \mathrm{Ae}$ & $7,877 \mathrm{Aa}$ & $8,102 \mathrm{Ad}$ & $8,022 \mathrm{Ac}$ & $8,021 \mathrm{Ac}$ \\
\hline 24 & $8,158 \mathrm{Bb}$ & $7,879 \mathrm{Bf}$ & $8,202 \mathrm{Ba}$ & $8,259 \mathrm{Bd}$ & $7,845 \mathrm{Bc}$ & $8,296 \mathrm{Be}$ \\
\hline 48 & $8,170 \mathrm{Cb}$ & $7,799 \mathrm{Cf}$ & $8,314 \mathrm{Ca}$ & $8,254 \mathrm{BCd}$ & $7,789 \mathrm{Cc}$ & $8,356 \mathrm{Ce}$ \\
\hline 72 & $8,152 \mathrm{BDb}$ & $7,732 \mathrm{Df}$ & $8,281 \mathrm{Da}$ & $8,239 \mathrm{Dd}$ & $7,637 \mathrm{Dc}$ & 8,420De \\
\hline
\end{tabular}

Obs.: Médias seguidas pelas mesmas letras, minúsculas nas linhas e maiúsculas nas colunas, não diferem entre si de acordo com o teste de Tukey ao nível de 1 \% de significância

Portanto, os resultados da presente pesquisa mostraram que apenas os meios de cultivo mais acidificados (Tabela 2 e 3; Figura 5A e 5B), aqueles inoculados com as bactérias $L$. fermentum ou $B$. subtilis, provocaram diminuição da viabilidade celular de S. cerevisiae (Tabela 5, Figura 6A). Os maiores valores de acidez total corresponderam com as menores porcentagens de viabilidade de S. cerevisiae, pois nos cultivos misto de S. cerevisiae com L. fermentum ou $B$. subtilis os valores de acidez total (Tabela 2) durante as 72 horas do ensaio atingiram médias de 6,4 e 2,9 g/L, expressos em ácido acético, enquanto que a viabilidade da levedura (Tabela 5) reduziu em 73,5 e 59,2\%, respectivamente.

Estes resultados concordam com os obtidos por diversos autores, os quais também observaram correlação entre o aumento da acidez do meio e a diminuição da viabilidade celular da levedura em cultivo associado com bactérias.

Amorim \& Oliveira (1982) citaram que as bactérias contaminantes causam prejuízos à fermentação e inibem o crescimento da levedura através da produção de ácido lático e outros ácidos orgânicos.

Alterthum et al. (1984), observaram que a elevada porcentagem de células mortas e o aumento da acidez do mosto são devidos à liberação no meio de cultura de substâncias tóxicas produzidas pelas células bacterianas, promovendo a morte da levedura ou dificultando seu desenvolvimento. 
Oliva-Neto (1990), determinou que quando a acidez total atinge valores superiores a 4,8 g/L, expressos em ácido lático, ocorre uma correlação inversa entre a acidez e a viabilidade das leveduras e, ainda, entre a acidez e a porcentagem de brotos vivos do fermento.

Yokoya (1991) observou que a presença de bactérias láticas na fermentação causam aumento da acidez do vinho pela produção de ácidos lático e acético, e acarretam queda na porcentagem de células vivas das leveduras.

Chin e Ingledew (1994) relataram que a contaminação com aproximadamente $10^{8} \mathrm{UFC} / \mathrm{mL}$ de bactérias produtoras de ácido lático não afetou seriamente a produtividade em etanol na fermentação de malte de trigo, porém ocasionou a uma redução de $60 \%$ na viabilidade da levedura.

Freguglia (1997), estudando a viabilidade celular de $S$. cerevisiae em cultura mista com $L$. fermentum, observou que a presença da bactéria e/ou de seus produtos metabólicos reduziram a viabilidade celular da levedura em $97 \%$ e $55 \%$, respectivamente, após 12 horas de cultivo associado.

Thomas et al. (2001) pesquisaram o efeito dos lactobacilos (L. collinoides, L. fermentum, L. plantarum e L. paracasei) em cultura mista com S. cerevisiae e relataram que a presença das bactérias estabelecidas na fermentação antes que as leveduras tivessem a chance de crescer e multiplicar, ocasionou aumento do desvio de carboidratos para a produção de ácido lático, queda na viabilidade e redução na formação de massa celular de levedura. Entretanto, os mesmos autores observaram que quando as bactérias foram inoculadas ao mesmo tempo e com o mesmo nível que as leveduras, de $10^{7}$ células $/ \mathrm{mL}$, o crescimento das bactérias foi inibido e a viabilidade da levedura não foi significativamente afetada.

Como em Thomas et al. (2001), neste trabalho algumas bactérias como, B. stearothermophilus ou B. coagulans ou L. plantarum, em cultivo misto com $S$. cerevisiae não influenciaram a viabilidade celular da levedura (Tabela 5, Figura $6 \mathrm{~A})$, este resultado também foi obtido por outros autores, os quais também 
observaram que a viabilidade celular da levedura não foi afetada pela presença das bactérias em diferentes mostos de fermentação.

Bayrock e Ingledew (2001), introduzindo L. paracasei como contaminante num sistema contínuo de fermentação nas proporções de 1:100, 1:1 e 70:1 com S. cerevisiae, observaram que mesmo na maior proporção, nem a bactéria ou seus produtos metabólicos (ácido lático) afetaram a concentração de etanol e a viabilidade da levedura. Em outro trabalho dos mesmo autores (2005) novamente, observaram que a presença de $L$. paracasei com 3,7 x $10^{5} \mathrm{UFC} / \mathrm{mL}$ não afetou o número de células viáveis de $S$. cerevisiae, e ainda produziu mais $18 \%$ de etanol quando comparado com a fermentação sem a presença do contaminante.

Cherubin (2003) num experimento comparativo entre linhagens de $S$. cerevisiae em cultura pura e em cultura mista com a bactéria $L$. fermentum durante 6 reciclos fermentativos constatou que não houve relação entre contaminação bacteriana e viabilidade de levedura.

Nossos resultados demonstram que a viabilidade celular de $S$. cerevisiae não foi afetada pela presença das bactérias (B. stearothermophilus ou $B$. coagulans ou L. plantarum) e isto pode ter ocorrido porque o nível de inoculação das bactérias não foi suficiente para competir em número de células com $S$. cerevisiae, ou fatores ambientais (como etanol, levedura, temperatura, pH) não permitiram um rápido e suficiente desenvolvimento das bactérias ou o meio era nutricionalmente deficiente.

Os níveis de inoculações das bactérias, em média de $10^{6}-10^{8} \mathrm{UFC} / \mathrm{mL}$ (Tabela 1), é considerado por diversos autores prejudiciais a levedura; o meio de cultivo foi adicionado de peptona e extrato de levedura, e este, segundo Oliva-Neto e Yokoya (1997), pode ser responsável pela estimulação do crescimento bacteriano; portanto assume-se que algum fator ambiental pode ter interferido no desenvolvimento das bactérias fazendo com que elas pouco produzissem ácidos. 
De acordo com Bayrock e Ingledew (2001) contaminantes podem existir mesmo que os parâmetros de produção demonstrem valores considerados "normais". Porém, o menor e estável nível de contaminação deve ser considerado como uma "bomba-relógio"; se as condições como pH, temperatura e outros mudarem, a contaminação pode surpreendentemente aumentar e causar problemas.

\subsection{Cultivos mistos de $S$. cerevisiae e bactérias tratadas}

As culturas de bactérias foram tratadas através do calor, de agente antimicrobiano e de irradiação, 24 horas antes das misturas com S. cerevisiae.

O processo de inativação através do calor proporcionou esterilização das culturas bacterianas. O antimicrobiano Kamoran $\mathrm{HJ}$, na dose de 3,0 mg/L, não foi suficiente para a completa inativação das bactérias estudadas em 24 horas. A radiação gama, nas doses utilizadas para os diferentes gêneros de bactérias (5,0 kGy para os Lactobacillus e 15,0 kGy para os Bacillus) inativou completamente os Lactobacillus, mas não foi suficiente para inativar totalmente os Bacillus.

As ações dos tratamentos foram avaliadas para cada espécie de bactéria através de plaqueamentos, em meios de cultivos convencionais (PCA para as bactérias do gênero Bacillus e MRS-agar para as bactérias do gênero Lactobacillus), prévio e após 24 horas de aplicação, obtendo-se os seguintes efeitos (Tabela 8, 9 e 10). 
Tabela 8. Eficiência do tratamento calor úmido

\begin{tabular}{|c|c|c|c|}
\hline \multicolumn{3}{|c|}{ CONTAGEM BACTERIOLÓGICA (UFC/mL)* } & \multirow{2}{*}{$\begin{array}{c}\text { EFICIÊNCIA } \\
\text { TRATAMENTO (\%) }\end{array}$} \\
\hline Bactéria & Prévia* & Remanescente * & \\
\hline B. stearothermophilus & $8,3 \times 10^{7}$ & 0 & 100,0 \\
\hline B. coagulans & $4,5 \times 10^{7}$ & 0 & 100,0 \\
\hline B. subtilis & $6,2 \times 10^{7}$ & 0 & 100,0 \\
\hline L. fermentum & $1,8 \times 10^{7}$ & 0 & 100,0 \\
\hline L. plantarum & $4,6 \times 10^{7}$ & 0 & 100,0 \\
\hline
\end{tabular}

* Média de 12 plaqueamentos

* Prévia = população bacteriana anterior ao tratamento

* Remanescente = população bacteriana após 24 horas de aplicação do tratamento

Tabela 9. Eficiência do tratamento antimicrobiano com Kamoran $\mathrm{HJ}$

\begin{tabular}{|c|c|c|c|}
\hline \multicolumn{3}{|c|}{ CONTAGEM BACTERIOLÓGICA (UFC/mL)* } & \multirow{2}{*}{$\begin{array}{c}\text { EFICIÊNCIA } \\
\text { TRATAMENTO (\%) }\end{array}$} \\
\hline Bactéria & Prévia* & Remanescente * & \\
\hline B. stearothermophilus & $7,1 \times 10^{7}$ & $4,4 \times 10^{4}$ & 99,94 \\
\hline B. coagulans & $5,8 \times 10^{7}$ & $9,0 \times 10^{3}$ & 99,98 \\
\hline B. subtilis & $7,9 \times 10^{7}$ & $1,2 \times 10^{4}$ & 99,98 \\
\hline L. fermentum & $6,8 \times 10^{7}$ & $1,6 \times 10^{4}$ & 99,98 \\
\hline L. plantarum & $7,0 \times 10^{7}$ & $1,3 \times 10^{3}$ & 99,99 \\
\hline
\end{tabular}

* Média de 12 plaqueamentos

* Prévia = população bacteriana anterior ao tratamento

* Remanescente = população bacteriana após 24 horas de aplicação do tratamento

Tabela 10. Eficiência do tratamento irradiação

\begin{tabular}{|c|c|c|c|}
\hline \multicolumn{3}{|c|}{ CONTAGEM BACTERIOLÓGICA (UFC/mL)* } & \multirow{2}{*}{$\begin{array}{c}\text { EFICIÊNCIA } \\
\text { TRATAMENTO (\%) }\end{array}$} \\
\hline Bactéria & Prévia* & Remanescente * & \\
\hline B. stearothermophilus & $8,3 \times 10^{7}$ & $8,6 \times 10^{2}$ & 99,99 \\
\hline B. coagulans & $4,5 \times 10^{7}$ & $3,4 \times 10^{2}$ & 99,99 \\
\hline B. subtilis & $6,2 \times 10^{7}$ & $6,2 \times 10^{3}$ & 99,99 \\
\hline L. fermentum & $1,8 \times 10^{7}$ & 0 & 100,0 \\
\hline L. plantarum & $4,6 \times 10^{7}$ & 0 & 100,0 \\
\hline
\end{tabular}

* Média de 12 plaqueamentos

* Prévia = população bacteriana anterior ao tratamento

* Remanescente = população bacteriana após 24 horas de aplicação do tratamento 
As Tabelas 8, 9 e 10 mostram as grandes eficiências dos diferentes tratamentos; o calor úmido foi capaz de inativar $100 \%$ das bactérias estudadas; o produto Kamoran $\mathrm{HJ}$ dentro da dosagem econômica industrial de 3 ppm, foi capaz de causar uma redução superior a 99,9\% e a radiação gama nas dosagens utilizadas foi capaz de causar uma redução superior a 99,9\% para bactérias do gênero Bacillus e de 100\% para bactérias do gênero Lactobacillus.

Os resultados do tratamento com antimicrobiano Kamoran $\mathrm{HJ}$ conferem com os obtidos por Alcarde (1995) que utilizando o mesmo produto dentro da dosagem econômica industrial de 3 ppm observou elevadas porcentagens de reduções populacionais em bactérias contaminantes da fermentação alcoólica, confirmando o acerto da dosagem a nível industrial.

Como no estudo realizado por Alcarde (2000), as bactérias do gênero Bacillus apresentaram maior resistência à inativação pela radiação gama que as bactérias do gênero Lactobacillus, por serem bactérias esporuladas. O autor encontrou doses de radiação $\mathrm{D}^{10}$, em média, 4 vezes maior para os Bacillus do que para os Lactobacillus.

Apesar das grandes eficiências dos tratamentos com antimicrobiano ou irradiação, houveram populações remanescentes que, através das contagens bacterianas (UFC/mL) apresentadas nas Tabelas 11 e 12, confirmaram a sobrevivência e mostraram o comportamento das bactérias durante os ensaios, envolvendo bactérias tratadas e $S$. cerevisiae. Os plaqueamentos foram realizados com meios de cultivos convencionais (PCA para as bactérias do gênero Bacillus e MRS-agar para as bactérias do gênero Lactobacillus). 
Tabela 11. Contagem bacteriana inicial e final dos cultivos mistos de bactérias tratadas com antimicrobiano Kamoran $\mathrm{HJ}$ e S. cerevisiae

\begin{tabular}{lcc}
\hline & CONTAGEM BACTERIANA (UFC/mL)* \\
\hline Bactéria & Inicial $(0 \mathrm{~h})^{\star}$ & Final $(72 \mathrm{~h})^{\star}$ \\
\hline B. stearothermophilus & $2,2 \times 10^{4}$ & $3,1 \times 10^{4}$ \\
B. coagulans & $4,5 \times 10^{3}$ & $1,8 \times 10^{4}$ \\
B. subtilis & $5,9 \times 10^{3}$ & $4,9 \times 10^{4}$ \\
L. fermentum & $8,0 \times 10^{3}$ & $8,8 \times 10^{3}$ \\
L. plantarum & $6,3 \times 10^{2}$ & 0 \\
\hline
\end{tabular}

* Média de 12 plaqueamentos

* Inicial $(0 \mathrm{~h})$ = início do período de incubação das culturas mistas de bactérias tratadas com antimicrobiano Kamoran $\mathrm{HJ}$ e S. cerevisiae

* Final $(72 \mathrm{~h})=$ final do período de cultivo misto

Tabela 12. Contagem bacteriana inicial e final dos cultivos mistos de bactérias tratadas com radiação gama e $S$. cerevisiae

CONTAGEM BACTERIANA (UFC/mL)*

\begin{tabular}{lcc}
\hline Bactéria & Inicial $(0 \mathrm{~h})^{\star}$ & Final $(72 \mathrm{~h})^{\star}$ \\
\hline B. stearothermophilus & $4,3 \times 10^{2}$ & $1,6 \times 10^{3}$ \\
B. coagulans & $1,7 \times 10^{2}$ & $5,2 \times 10^{3}$ \\
B. subtilis & $3,1 \times 10^{3}$ & $3,1 \times 10^{3}$ \\
L. fermentum & 0 & 0 \\
L. plantarum & 0 & 0 \\
\hline
\end{tabular}

* Média de 12 plaqueamentos

* Inicial $(0 \mathrm{~h})$ = início do período de incubação das culturas mistas de bactérias tratadas com radiação gama e $S$. cerevisiae

* Final $(72 \mathrm{~h})=$ final do período de cultivo misto

Observa-se pela Tabela 11 que o crescimento de $B$. stearothermophilus, $B$. coagulans e $B$. subtilis tratadas com Kamoran $\mathrm{HJ}$ em cultura mista com $\mathrm{S}$. cerevisiae apresentaram um desenvolvimento pequeno em 72 horas de cultivo, mas progressivo e competitivo por substrato, enquanto as espécies de $L$. fermentum e L. plantarum tratadas com Kamoran $\mathrm{HJ}$ foram mantidas praticamente latentes ou desprezíveis diante da população de $S$. cerevisiae, da ordem de 4,4 X $10^{8} \mathrm{UFC} / \mathrm{mL}$ no cultivo controle, após 72 horas. 
A mesma tendência de comportamento foi observada para as bactérias do gênero Bacillus tratadas com radiação gama na Tabela 12, onde as contagens bacterianas inicial e final também demonstraram um desenvolvimento pequeno durante o ensaio, mas competitivo por substrato. Como neste tratamento as bactérias do gênero Lactobacillus foram totalmente inativadas (Tabela 10), os resultados das contagens bacterianas subsequentes foram nulas (Tabela 12).

De modo geral, a acidez total (Figura 7A, 8A e 9A) e a acidez volátil (Figura 7B, 8B e 9B) dos meios de cultivos inoculados ou não, com as bactérias tratadas pelos diferentes tratamentos (calor, antimicrobiano e irradiação), aumentaram até as 24 horas iniciais dos cultivos, vindo posteriormente a diminuir até as 72 horas, término dos cultivos. E consequentemente $\mathrm{opH}$ (Figura 7C, 8C e 9C) desses meios apresentou tendência inversa, isto é, diminuiu até $24 \mathrm{~h}$ e, em seguida, aumentou até $72 \mathrm{~h}$ dos cultivos mistos de bactérias tratadas e $S$. cerevisiae e do cultivo isolado de $S$. cerevisiae. 

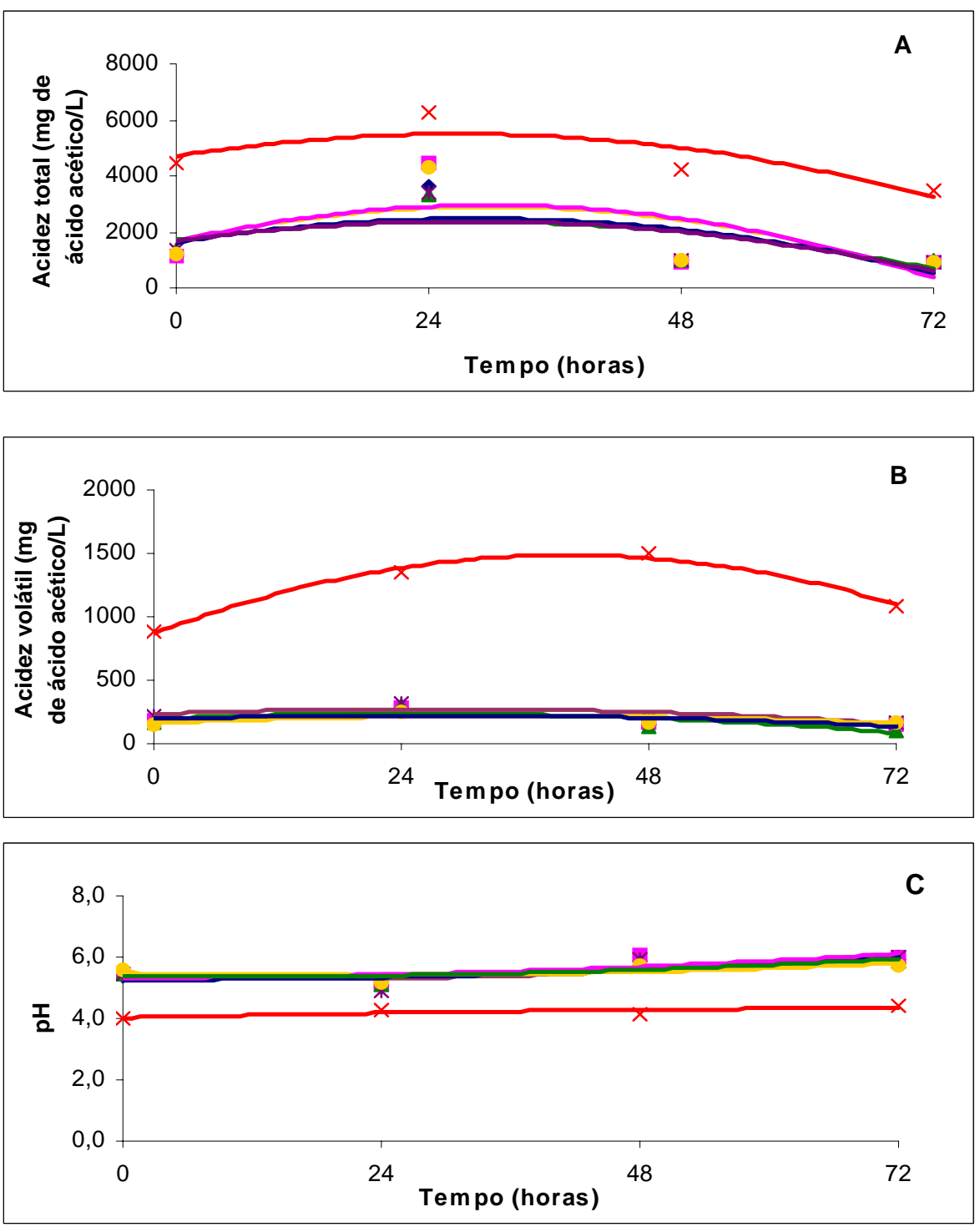

Figura 7 - Variações das determinações físico-químicas: acidez total (A), acidez volátil (B) e pH (C); durante o cultivo misto de $S$. cerevisia com as bactérias tratadas pelo calor úmido: B. stearothermophilus $(\diamond)$, B. coagulans $(\square)$, B. subtilis $(\Delta)$, L. fermentum (X), L. plantarum (*); e o controle ( $)$ refere-se de S. cerevisiae cultivada sem a presença de bactérias 

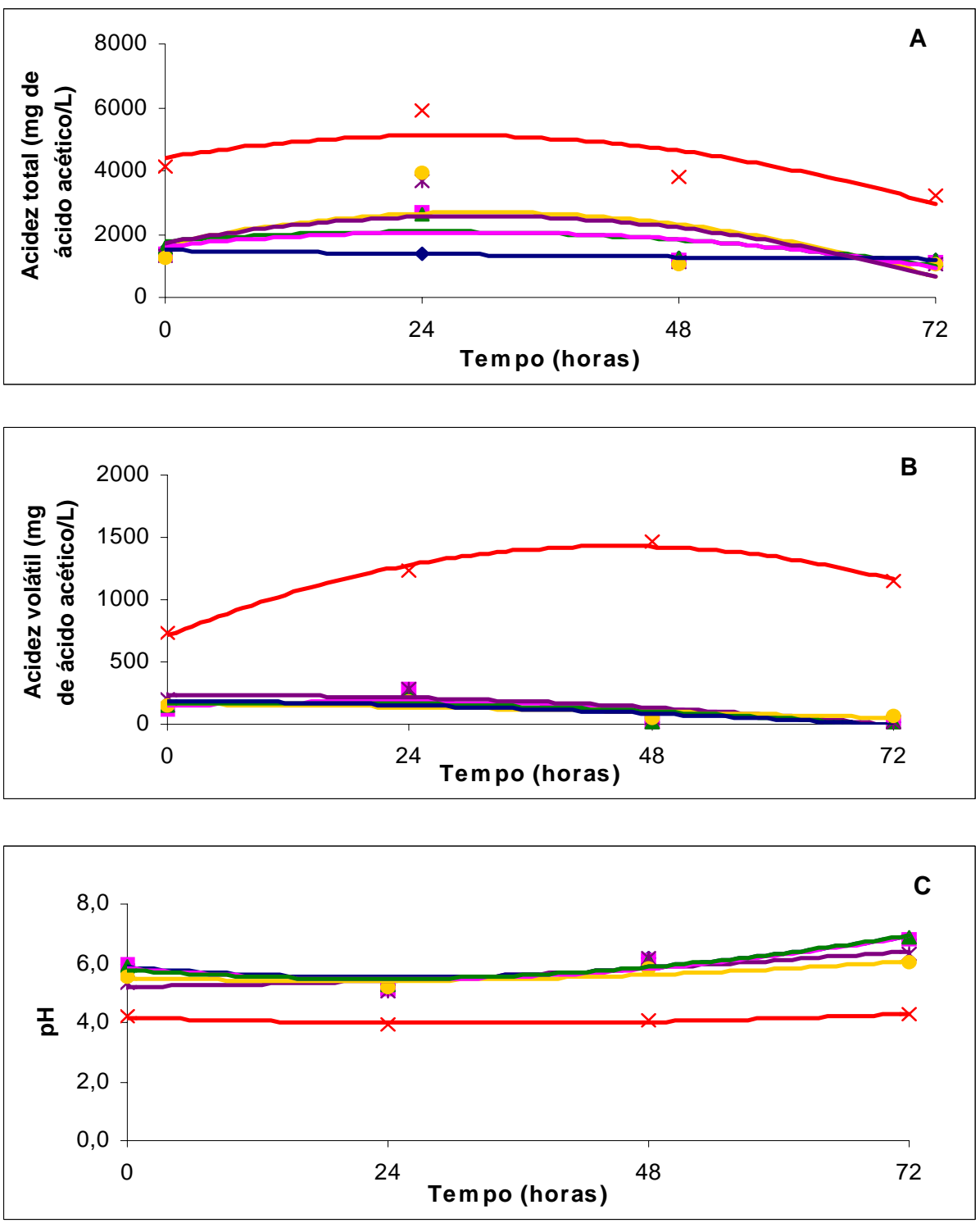

Figura 8 - Variações das determinações físico-químicas: acidez total (A), acidez volátil (B) e pH (C); durante o cultivo misto de $S$. cerevisia com as bactérias tratadas pelo antimicrobiano Kamoran $\mathrm{HJ}$ : B. stearothermophilus $(\diamond)$, B. coagulans $(\square), B$. subtilis ( $\bullet$ ), L. fermentum (X), L. plantarum (*); e o controle $(\bigcirc)$ refere-se de $S$. cerevisiae cultivada sem a presença de bactérias 

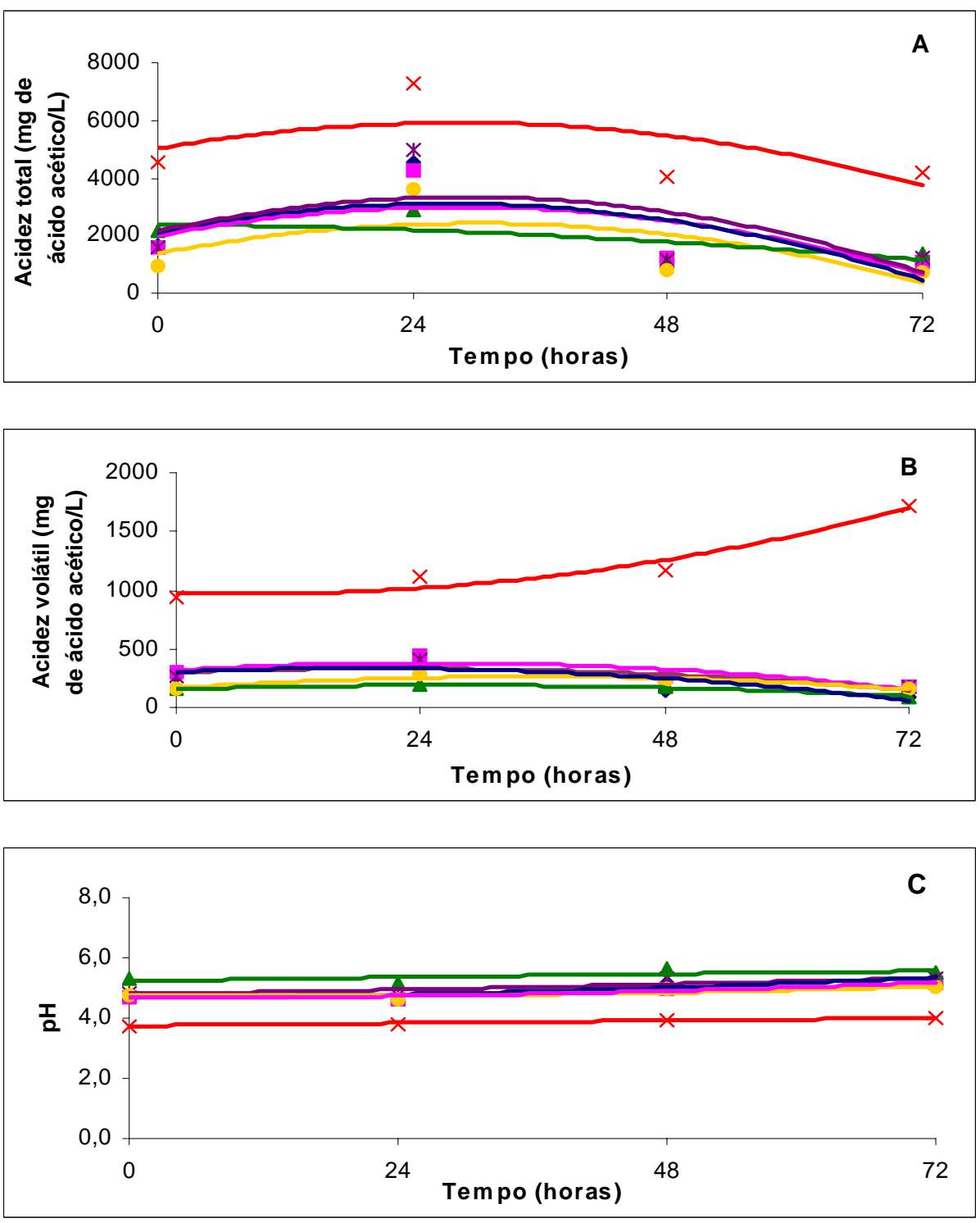

Figura 9 - Variações das determinações físico-químicas: acidez total (A), acidez volátil (B) e pH (C); durante o cultivo misto de S. cerevisia com as bactérias tratadas por irradiação: B. stearothermophilus $(\bullet)$, B. coagulans $(\square)$, B. subtilis $(\bullet)$, L. fermentum $(\mathbf{X}), L$. plantarum (*); e o controle $(\odot)$ refere-se de $S$. cerevisiae cultivada sem a presença de bactérias 
Através da acidez total (Tabela 13, 14 e 15) observa-se acidificação inicial, após 24 horas de incubação, diferindo significativamente em relação aos demais períodos (0, 48 e $72 \mathrm{~h}$ ), em todos os meios de cultivos, inoculados ou não, com as bactérias tratadas pelos diferentes tratamentos.

Os valores de acidez total dos cultivos mistos de $S$. cerevisiae $\operatorname{com} B$. stearothermophilus ou B. coagulans ou $L$. plantarum ou B. subtilis tratadas pelo calor, não diferiram estatisticamente do controle (Tabela 13). Nestes casos, como os valores de acidez total desde o início foram semelhantes ao controle, observase que os ácidos, novamente, foram produzidos quase que exclusivamente por $S$. cerevisiae, já que a população remanescente aos tratamentos foi insignificante e pouco competitiva por nutrientes.

É interessante observar ainda que a acidez total de todos os cultivos mistos tratados com antimicrobiano ou radiação gama seguem a mesma tendência do cultivo controle de S. cerevisiae apesar de diferirem estatisticamente (Tabela $14 \mathrm{e}$ 15), à exceção de L. fermentum, uma eficiente produtora de ácido lático, demonstrado pelo teor encontrado no cultivo a $0 \mathrm{~h}$ e cuja forma produzida seja menos assimilada até $72 \mathrm{~h}$ de cultivo. Pelos teores apresentados nos cultivos mistos das espécies de Bacillus em estudo e de L. plantarum, essas bactérias são baixas produtoras de ácidos e provavelmente suas presenças em fermentações tragam prejuízos na competição por substrato mais que efeitos de prováveis toxinas.

Ao contrário dos outros cultivos mistos, L. fermentum tratado por qualquer um dos tratamentos, apresentou valores de acidez total superiores ao controle durante todos os ensaios, e diferiram estatisticamente do controle (Tabela 13, 14 e 15), sugerindo, novamente, que, nestas condições de cultivo, esta bactéria, entre os microrganismos estudados, foi a mais eficiente produtora de ácidos orgânicos. 
Tabela 13. Teste de Tukey para as médias de acidez total, comparando os microrganismos e os períodos, em cultura mista de S. cerevisiae e bactérias tratadas com calor

\begin{tabular}{c|c|c|c|c|c|c}
\hline \multirow{2}{*}{$\begin{array}{c}\text { Períodos } \\
\text { (horas) }\end{array}$} & $\begin{array}{c}|c| \\
\text { Cultivo misto de S. cerevisiae com }\end{array}$ & \multirow{2}{*}{$\begin{array}{c}\text { S. cerevisiae } \\
\text { (controle) }\end{array}$} \\
\cline { 2 - 6 } & $\begin{array}{c}\text { Bacillus } \\
\text { stearothermophilus }\end{array}$ & $\begin{array}{c}\text { Bacillus } \\
\text { subtilis }\end{array}$ & $\begin{array}{c}\text { Bacillus } \\
\text { coagulans }\end{array}$ & $\begin{array}{c}\text { Lactobac. } \\
\text { plantarum }\end{array}$ & $\begin{array}{c}\text { Lactobac. } \\
\text { fermentum }\end{array}$ & \\
\hline 0 & $1239 \mathrm{Aa}$ & $1388 \mathrm{Aa}$ & $1125 \mathrm{Aa}$ & $1337 \mathrm{Aa}$ & $4451 \mathrm{Ab}$ & $1177 \mathrm{Aa}$ \\
\hline 24 & $3592 \mathrm{Bb}$ & $3351 \mathrm{Bbd}$ & $4485 \mathrm{Ba}$ & $3364 \mathrm{Bd}$ & $6250 \mathrm{Bc}$ & $4315 \mathrm{Ba}$ \\
\hline 48 & $949 \mathrm{ACa}$ & $995 \mathrm{Ca}$ & $884 \mathrm{Aa}$ & $986 \mathrm{Ca}$ & $4427 \mathrm{Ab}$ & $962 \mathrm{Aa}$ \\
\hline 72 & $904 \mathrm{Ca}$ & $1003 \mathrm{Ca}$ & $891 \mathrm{Aa}$ & $921 \mathrm{Ca}$ & $3488 \mathrm{Cb}$ & $952 \mathrm{Aa}$ \\
\hline
\end{tabular}

Obs.: Médias seguidas pelas mesmas letras, minúsculas nas linhas e maiúsculas nas colunas, não diferem entre si de acordo com o teste de Tukey ao nível de 1 \% de significância

Tabela 14. Teste de Tukey para as médias de acidez total, comparando os microrganismos e os períodos, em cultura mista de $S$. cerevisiae e bactérias tratadas com Kamoran $\mathrm{HJ}$

\begin{tabular}{|c|c|c|c|c|c|c|}
\hline & \multicolumn{5}{|c|}{ Cultivo misto de S. cerevisiae com } & \multirow[b]{2}{*}{$\begin{array}{l}\text { S. cerevisiae } \\
\text { (controle) }\end{array}$} \\
\hline $\begin{array}{l}\text { Períodos } \\
\text { (horas) }\end{array}$ & $\begin{array}{c}\text { Bacillus } \\
\text { stearothermophilus }\end{array}$ & $\begin{array}{l}\text { Bacillus } \\
\text { subtilis }\end{array}$ & $\begin{array}{l}\text { Bacillus } \\
\text { coagulans }\end{array}$ & $\begin{array}{l}\text { Lactobac. } \\
\text { plantarum }\end{array}$ & $\begin{array}{l}\text { Lactobac. } \\
\text { fermentum }\end{array}$ & \\
\hline & \multicolumn{6}{|c|}{ Acidez Total (mg ácido acético / L) } \\
\hline 0 & $1486 \mathrm{Aa}$ & $1594 \mathrm{Ad}$ & 1405 Aacd & $1344 \mathrm{Aac}$ & $4142 \mathrm{Ab}$ & $1265 \mathrm{Ac}$ \\
\hline 24 & $1369 \mathrm{ABb}$ & $2635 \mathrm{Ba}$ & $2688 \mathrm{Ba}$ & $3656 \mathrm{Bd}$ & $5903 \mathrm{Bc}$ & $3919 \mathrm{Be}$ \\
\hline 48 & $1275 \mathrm{BCa}$ & $1254 \mathrm{Ca}$ & $1196 \mathrm{Cac}$ & $1083 \mathrm{Ccd}$ & $3829 \mathrm{Cb}$ & $1038 \mathrm{Cd}$ \\
\hline 72 & $1211 \mathrm{Ca}$ & $1188 \mathrm{Ca}$ & $1145 \mathrm{Cac}$ & $1031 \mathrm{Cc}$ & $3204 \mathrm{Db}$ & $1078 \mathrm{Cac}$ \\
\hline
\end{tabular}

Obs.: Médias seguidas pelas mesmas letras, minúsculas nas linhas e maiúsculas nas colunas, não diferem entre si de acordo com o teste de Tukey ao nível de 1 \% de significância

Tabela 15. Teste de Tukey para as médias de acidez total, comparando os microrganismos e os períodos, em cultura mista de S. cerevisiae e bactérias tratadas com irradiação

\begin{tabular}{|c|c|c|c|c|c|c|}
\hline \multirow{3}{*}{$\begin{array}{c}\text { Períodos } \\
\text { (horas) }\end{array}$} & \multicolumn{5}{|c|}{ Cultivo misto de S. cerevisiae com } & \multirow{2}{*}{$\begin{array}{l}\text { S. cerevisiae } \\
\text { (controle) }\end{array}$} \\
\hline & $\begin{array}{c}\text { Bacillus } \\
\text { stearothermophilus }\end{array}$ & $\begin{array}{l}\text { Bacillus } \\
\text { subtilis }\end{array}$ & $\begin{array}{c}\text { Bacillus } \\
\text { coagulans }\end{array}$ & $\begin{array}{l}\text { Lactobac. } \\
\text { plantarum }\end{array}$ & $\begin{array}{l}\text { Lactobac. } \\
\text { fermentum }\end{array}$ & \\
\hline & \multicolumn{6}{|c|}{ Acidez Total (mg ácido acético / L) } \\
\hline 0 & $1594 \mathrm{Aa}$ & $2161 \mathrm{Ad}$ & $1566 \mathrm{Aa}$ & $1601 \mathrm{Aa}$ & $4544 \mathrm{Ab}$ & $970 \mathrm{Ac}$ \\
\hline 24 & $4472 \mathrm{Ba}$ & $2851 \mathrm{Be}$ & $4200 \mathrm{Ba}$ & $4913 \mathrm{Bc}$ & $7140 \mathrm{Bb}$ & $3593 \mathrm{Bd}$ \\
\hline 48 & $1051 \mathrm{Cac}$ & $1109 \mathrm{Cac}$ & $1257 \mathrm{Aa}$ & $1155 \mathrm{Cac}$ & $4040 \mathrm{Cb}$ & $825 \mathrm{Ac}$ \\
\hline 72 & 979 Cac & $1314 \mathrm{Ca}$ & $1091 \mathrm{Cac}$ & $1256 \mathrm{ACa}$ & $4193 \mathrm{ACb}$ & $750 \mathrm{Ac}$ \\
\hline
\end{tabular}

Obs.: Médias seguidas pelas mesmas letras, minúsculas nas linhas e maiúsculas nas colunas, não diferem entre si de acordo com o teste de Tukey ao nível de 1 \% de significância 
Os valores de acidez volátil, dos cultivos mistos das bactérias tratadas com calor úmido ou antimicrobiano e S. cerevisiae, exceto quando em cultivo misto com L. fermentum, não apresentaram diferença significativa entre os microrganismos estudados e o controle. O aumento da acidez volátil verificado às $24 \mathrm{~h}$ de cultivo pode ser notado nas Tabelas 16 e 17, e a queda destes valores após $48 \mathrm{~h}$ de cultivo fica evidente nos cultivos mistos de $\mathrm{S}$. cerevisiae e B. stearothermophilus, ou B. subtilis, ou B. coagulans ou L. plantarum.

Apesar dos valores de acidez volátil (Tabela 18), dos cultivos misto de $S$. cerevisiae e B. stearothermophilus, ou $B$. subtilis, ou $B$. coagulans ou $L$. plantarum tratadas com radiação gama, apresentarem diferença significativa em relação ao o controle, a variável demonstrou uma mesma tendência de aumentar nas $24 \mathrm{~h}$ do período de incubação, vindo posteriormente a diminuir até o final do período.

Como na acidez total, os valores de acidez volátil do cultivo misto de $S$. cerevisiae com L. fermentum tratada com qualquer um dos tratamentos, desde o início do período de incubação $(0 \mathrm{~h})$ até o final $(72 \mathrm{~h})$, foram estatisticamente diferentes do controle (Tabelas 16, 17 e 18).

Tabela 16. Teste de Tukey para as médias de acidez volátil, comparando os microrganismos e os períodos, em cultura mista de $S$. cerevisiae e bactérias tratadas com calor

\begin{tabular}{c|c|c|c|c|c|c}
\hline \multirow{2}{*}{$\begin{array}{c}\text { Períodos } \\
\text { (horas) }\end{array}$} & \multicolumn{5}{|c|}{ Cultivo misto de S. cerevisiae com } & \multirow{2}{*}{$\begin{array}{c}\text { S. cerevisiae } \\
\text { (controle) }\end{array}$} \\
\cline { 2 - 6 } & $\begin{array}{c}\text { Bacillus } \\
\text { stearothermophilus }\end{array}$ & $\begin{array}{c}\text { Bacillus } \\
\text { subtilis }\end{array}$ & $\begin{array}{c}\text { Bacillus } \\
\text { coagulans }\end{array}$ & $\begin{array}{c}\text { Lactobac. } \\
\text { plantarum }\end{array}$ & $\begin{array}{c}\text { Lactobac. } \\
\text { fermentum }\end{array}$ & \\
\cline { 2 - 6 } & \multicolumn{6}{|c|}{ Acidez Volátil (mg ácido acético / L) } \\
\hline 0 & $175 \mathrm{Aa}$ & $174 \mathrm{Aa}$ & $176 \mathrm{Aa}$ & $219 \mathrm{Aa}$ & $882 \mathrm{Ab}$ & $149 \mathrm{Aa}$ \\
\hline 24 & $276 \mathrm{Ba}$ & $306 \mathrm{Ba}$ & $276 \mathrm{Ba}$ & $317 \mathrm{Ba}$ & $1344 \mathrm{Bb}$ & $251 \mathrm{Ba}$ \\
\hline 48 & $152 \mathrm{Aa}$ & $132 \mathrm{Aa}$ & $161 \mathrm{Aa}$ & $204 \mathrm{Aa}$ & $1503 \mathrm{Cb}$ & $171 \mathrm{ABa}$ \\
\hline 72 & $152 \mathrm{Aa}$ & $108 \mathrm{Aa}$ & $152 \mathrm{Aa}$ & $173 \mathrm{Aa}$ & $1084 \mathrm{Db}$ & $172 \mathrm{ABa}$ \\
\hline
\end{tabular}

Obs.: Médias seguidas pelas mesmas letras, minúsculas nas linhas e maiúsculas nas colunas, não diferem entre si de acordo com o teste de Tukey ao nível de 1 \% de significância 
Tabela 17. Teste de Tukey para as médias de acidez volátil, comparando os microrganismos e os períodos, em cultura mista de $S$. cerevisiae e bactérias tratadas com Kamoran $\mathrm{HJ}$

\begin{tabular}{|c|c|c|c|c|c|c|}
\hline \multirow{3}{*}{$\begin{array}{c}\text { Períodos } \\
\text { (horas) }\end{array}$} & \multicolumn{5}{|c|}{ Cultivo misto de S. cerevisiae com } & \multirow{2}{*}{$\begin{array}{l}\text { S. cerevisiae } \\
\text { (controle) }\end{array}$} \\
\hline & $\begin{array}{c}\text { Bacillus } \\
\text { stearothermophilus }\end{array}$ & $\begin{array}{l}\text { Bacillus } \\
\text { subtilis }\end{array}$ & $\begin{array}{c}\text { Bacillus } \\
\text { coagulans }\end{array}$ & $\begin{array}{l}\text { Lactobac. } \\
\text { plantarum }\end{array}$ & $\begin{array}{l}\text { Lactobac. } \\
\text { fermentum }\end{array}$ & \\
\hline & \multicolumn{6}{|c|}{ Acidez Volátil (mg ácido acético / I) } \\
\hline 0 & $166 \mathrm{Aa}$ & $145 \mathrm{Aa}$ & $110 \mathrm{Aa}$ & 201Aa & $729 \mathrm{Ab}$ & $148 \mathrm{Aa}$ \\
\hline 24 & $222 \mathrm{Aac}$ & $248 \mathrm{Bd}$ & $282 \mathrm{Ba}$ & $289 \mathrm{Aad}$ & $1228 \mathrm{Bb}$ & $183 \mathrm{Ac}$ \\
\hline 48 & $16 \mathrm{Ba}$ & $20 \mathrm{Ca}$ & $19 \mathrm{Ca}$ & $56 \mathrm{Ba}$ & $1474 \mathrm{Cb}$ & $54 \mathrm{Ba}$ \\
\hline 72 & $13 \mathrm{Ba}$ & $15 \mathrm{Ca}$ & $13 \mathrm{Ca}$ & $16 \mathrm{Ba}$ & $1144 \mathrm{Bb}$ & $64 \mathrm{Ba}$ \\
\hline
\end{tabular}

Obs.: Médias seguidas pelas mesmas letras, minúsculas nas linhas e maiúsculas nas colunas, não diferem entre si de acordo com o teste de Tukey ao nível de 1 \% de significância

Tabela 18. Teste de Tukey para as médias de acidez volátil, comparando os microrganismos e os períodos, em cultura mista de $S$. cerevisiae e bactérias tratadas com irradiação

\begin{tabular}{|c|c|c|c|c|c|c|}
\hline \multirow{3}{*}{$\begin{array}{c}\text { Períodos } \\
\text { (horas) }\end{array}$} & \multicolumn{5}{|c|}{ Cultivo misto de S. cerevisiae com } & \multirow{2}{*}{$\begin{array}{l}\text { S. cerevisiae } \\
\text { (controle) }\end{array}$} \\
\hline & $\begin{array}{c}\text { Bacillus } \\
\text { stearothermophilus }\end{array}$ & $\begin{array}{l}\text { Bacillus } \\
\text { subtilis }\end{array}$ & $\begin{array}{c}\text { Bacillus } \\
\text { coagulans }\end{array}$ & $\begin{array}{l}\text { Lactobac. } \\
\text { plantarum }\end{array}$ & $\begin{array}{l}\text { Lactobac. } \\
\text { fermentum }\end{array}$ & \\
\hline & \multicolumn{6}{|c|}{ Acidez Volátil (mg ácido acético / L) } \\
\hline 0 & $267 \mathrm{Aa}$ & $157 \mathrm{Ac}$ & $299 \mathrm{Aa}$ & $274 \mathrm{Aa}$ & $941 \mathrm{Ab}$ & $155 \mathrm{Ac}$ \\
\hline 24 & $439 \mathrm{Ba}$ & $188 \mathrm{Ad}$ & $439 \mathrm{Ba}$ & $408 \mathrm{Ba}$ & $1113 \mathrm{Bb}$ & $280 \mathrm{Bc}$ \\
\hline 48 & $141 \mathrm{Cb}$ & $170 \mathrm{Abd}$ & $267 \mathrm{Aa}$ & 204 Cde & $1161 \mathrm{Bc}$ & 222 Cae \\
\hline 72 & $94 \mathrm{Cb}$ & $95 \mathrm{Bb}$ & $173 \mathrm{Ca}$ & $173 \mathrm{Ca}$ & $1725 \mathrm{Cc}$ & $161 \mathrm{Aa}$ \\
\hline
\end{tabular}

Obs.: Médias seguidas pelas mesmas letras, minúsculas nas linhas e maiúsculas nas colunas, não diferem entre si de acordo com o teste de Tukey ao nível de 1 \% de significância

Através da Tabela 19, 20 e 21, fica evidente o aumento do pH ao longo do período de incubação para o controle e para a maioria dos cultivos mistos de S. cerevisiae com bactérias tratadas por qualquer um dos tratamentos.

Os valores de $\mathrm{pH}$, dos cultivos mistos das bactérias tratadas com calor úmido e $S$. cerevisiae (Tabela 19), exceto quando em cultivo misto com $L$. fermentum, não apresentaram diferença significativa entre os microrganismos estudados e o controle. Apesar dos valores de pH (Tabela 20 e 21), dos cultivos mistos de $S$. cerevisiae com $B$. stearothermophilus ou $B$. subtilis ou $B$. coagulans ou L. plantarum tratadas com antimicrobiano ou radiação gama, diferirem estatisticamente do controle, a variável demonstrou a mesma 
tendência, em todos os tratamentos, de diminuir nas $24 \mathrm{~h}$ do período de incubação, vindo posteriormente a aumentar até o final do período.

No cultivo misto de $S$. cerevisiae e $L$. fermentum tratado por calor úmido ou Kamoran $\mathrm{HJ}$ o $\mathrm{pH}$ mantêve-se constante entre os períodos e sempre menor e diferindo significativamente do controle (Tabelas 19 e 20). Esta mesma tendência é observada na Tabela 21 para o pH no cultivo misto de S. cerevisiae e $L$. fermentum tratado por radiação gama, porém, neste caso, o aumento a partir das 48 horas de cultivo é significativamente observado.

Tabela 19. Teste de Tukey para as médias de $\mathbf{p H}$, comparando os microrganismos e os períodos, em cultura mista de S. cerevisiae e bactérias tratadas com calor

\begin{tabular}{|c|c|c|c|c|c|c|}
\hline \multirow{3}{*}{$\begin{array}{c}\text { Períodos } \\
\text { (horas) }\end{array}$} & \multicolumn{5}{|c|}{ Cultivo misto de S. cerevisiae com } & \multirow{2}{*}{$\begin{array}{l}\text { S. cerevisiae } \\
\text { (controle) }\end{array}$} \\
\hline & $\begin{array}{c}\text { Bacillus } \\
\text { stearothermophilus }\end{array}$ & $\begin{array}{l}\text { Bacillus } \\
\text { subtilis }\end{array}$ & $\begin{array}{c}\text { Bacillus } \\
\text { coagulans }\end{array}$ & $\begin{array}{l}\text { Lactobac. } \\
\text { plantarum }\end{array}$ & $\begin{array}{l}\text { Lactobac. } \\
\text { fermentum }\end{array}$ & \\
\hline & \multicolumn{6}{|c|}{$\mathrm{pH}$} \\
\hline 0 & 5,37 Aca & $5,47 \mathrm{ABa}$ & $5,46 \mathrm{Aa}$ & $5,48 \mathrm{Aa}$ & $4,00 \mathrm{Ab}$ & $5,57 \mathrm{ABa}$ \\
\hline 24 & $5,04 \mathrm{BCa}$ & $5,12 \mathrm{Aa}$ & $5,07 \mathrm{Ba}$ & $4,96 \mathrm{Ba}$ & $4,29 \mathrm{Ab}$ & $5,18 \mathrm{Aa}$ \\
\hline 48 & $5,89 \mathrm{ABa}$ & $5,87 \mathrm{Ba}$ & $6,05 \mathrm{Aa}$ & $5,93 \mathrm{Ca}$ & $4,17 \mathrm{Ab}$ & $5,76 \mathrm{Ba}$ \\
\hline 72 & $5,91 \mathrm{Ca}$ & $5,85 \mathrm{Ba}$ & $6,00 \mathrm{Aa}$ & $6,01 \mathrm{Ca}$ & $4,38 \mathrm{Ab}$ & $5,72 \mathrm{Ba}$ \\
\hline
\end{tabular}

Obs.: Médias seguidas pelas mesmas letras, minúsculas nas linhas e maiúsculas nas colunas, não diferem entre si de acordo com o teste de Tukey ao nível de 1 \% de significância

Tabela 20. Teste de Tukey para as médias de $\mathbf{p H}$, comparando os microrganismos e os períodos, em cultura mista de $S$. cerevisiae e bactérias tratadas com Kamoran $\mathrm{HJ}$

\begin{tabular}{c|c|c|c|c|c|c}
\hline \multirow{2}{*}{$\begin{array}{c}\text { Períodos } \\
\text { (horas) }\end{array}$} & \begin{tabular}{c} 
Cultivo misto de S. cerevisiae com \\
Bacillus \\
\cline { 2 - 6 }
\end{tabular} & $\begin{array}{c}\text { Bacillus } \\
\text { subtilis }\end{array}$ & $\begin{array}{c}\text { Bacillus } \\
\text { soagulans }\end{array}$ & $\begin{array}{c}\text { Lactobac. } \\
\text { plantarum }\end{array}$ & $\begin{array}{c}\text { Lactobac. } \\
\text { fermentum }\end{array}$ & \\
\cline { 2 - 6 } (controle) \\
\hline 0 & $5,94 \mathrm{Aa}$ & $5,60 \mathrm{Aac}$ & $5,91 \mathrm{Aa}$ & $5,34 \mathrm{Ac}$ & $4,17 \mathrm{Ab}$ & $5,57 \mathrm{Aac}$ \\
\hline 24 & $5,24 \mathrm{Ba}$ & $5,23 \mathrm{Aa}$ & $5,16 \mathrm{Ba}$ & $5,08 \mathrm{Aa}$ & $3,98 \mathrm{Ab}$ & $5,24 \mathrm{ABa}$ \\
\hline 48 & $6,15 \mathrm{Aa}$ & $6,11 \mathrm{Ba}$ & $6,15 \mathrm{Aa}$ & $6,16 \mathrm{Ba}$ & $4,04 \mathrm{Ab}$ & $5,06 \mathrm{Bc}$ \\
\hline 72 & $6,82 \mathrm{Ca}$ & $6,85 \mathrm{Ca}$ & $6,81 \mathrm{Ca}$ & $6,29 \mathrm{Bc}$ & $4,30 \mathrm{Ab}$ & $5,98 \mathrm{Cc}$ \\
\hline
\end{tabular}

Obs.: Médias seguidas pelas mesmas letras, minúsculas nas linhas e maiúsculas nas colunas, não diferem entre si de acordo com o teste de Tukey ao nível de $1 \%$ de significância 
Tabela 21. Teste de Tukey para as médias de pH, comparando os microrganismos e os períodos, em cultura mista de $\mathrm{S}$. cerevisiae e bactérias tratadas com irradiação

\begin{tabular}{|c|c|c|c|c|c|c|}
\hline \multirow{3}{*}{$\begin{array}{c}\text { Períodos } \\
\text { (horas) }\end{array}$} & \multicolumn{5}{|c|}{ Cultivo misto de S. cerevisiae com } & \multirow{2}{*}{$\begin{array}{l}\text { S. cerevisiae } \\
\text { (controle) }\end{array}$} \\
\hline & $\begin{array}{c}\text { Bacillus } \\
\text { stearothermophilus }\end{array}$ & $\begin{array}{l}\text { Bacillus } \\
\text { subtilis }\end{array}$ & $\begin{array}{c}\text { Bacillus } \\
\text { coagulans }\end{array}$ & $\begin{array}{l}\text { Lactobac. } \\
\text { plantarum }\end{array}$ & $\begin{array}{l}\text { Lactobac. } \\
\text { fermentum }\end{array}$ & \\
\hline & \multicolumn{6}{|c|}{$\mathrm{pH}$} \\
\hline 0 & $4,72 \mathrm{Aa}$ & $5,27 \mathrm{Ad}$ & $4,70 \mathrm{Aa}$ & $4,86 \mathrm{Ac}$ & $3,77 \mathrm{Ab}$ & $4,77 \mathrm{Aac}$ \\
\hline 24 & $4,63 \mathrm{Aac}$ & $5,19 \mathrm{Ae}$ & $4,65 \mathrm{Aa}$ & $4,77 \mathrm{Ad}$ & $3,82 \mathrm{Ab}$ & $4,64 \mathrm{Acd}$ \\
\hline 48 & $5,17 \mathrm{Bb}$ & $5,64 \mathrm{Bd}$ & $5,00 \mathrm{Ba}$ & $5,28 \mathrm{Bb}$ & $3,94 \mathrm{Bc}$ & $4,95 \mathrm{Ba}$ \\
\hline 72 & $5,31 \mathrm{Cb}$ & $5,51 \mathrm{Be}$ & $5,16 \mathrm{Ca}$ & $5,28 \mathrm{Bab}$ & $4,01 \mathrm{Bc}$ & $5,02 \mathrm{Bd}$ \\
\hline
\end{tabular}

Obs.: Médias seguidas pelas mesmas letras, minúsculas nas linhas e maiúsculas nas colunas, não diferem entre si de acordo com o teste de Tukey ao nível de 1 \% de significância

Há que se destacar o comportamento da bactéria $L$. fermentum em cultivo misto com S. cerevisiae. Os meios inoculados com essa bactéria tratada pelos diferentes processos apresentaram os maiores valores de acidez, tanto total (Figuras 7A, 8A e 9A) quanto volátil (Figuras 7B, 8B e 9B), e, conseqüentemente, os menores valores de $\mathrm{pH}$ (Figuras 7C, $8 \mathrm{C}$ e 9C) sugerindo novamente que, nestas condições de cultivo, esta bactéria entre os microrganismos estudados foi a mais eficiente produtora de ácidos orgânicos.

Os demais meios de cultivo inoculados com as outras bactérias tratadas através dos diferentes processos, de um modo geral, apresentaram acidez total (Figuras 7A, 8A e 9A), acidez volátil (Figuras 7B, 8B e 9B) e pH (Figuras 7C, 8C e 9C) semelhantes ao tratamento controle (S. cerevisiae).

De um modo geral a viabilidade celular de S. cerevisiae (Figura 10A, 11A e 12A) não foi afetada pelas diferentes bactérias tratadas por qualquer tratamento, a taxa de brotamento de S. cerevisiae (Figura 10B, 11B e 12B) não apresentou uma tendência definida, porém diminuiu ao longo do período de incubação, e a população de células de S. cerevisiae (Figura 10C, 11C e 12C) apresentou-se sempre ligeiramente abaixo do controle. 

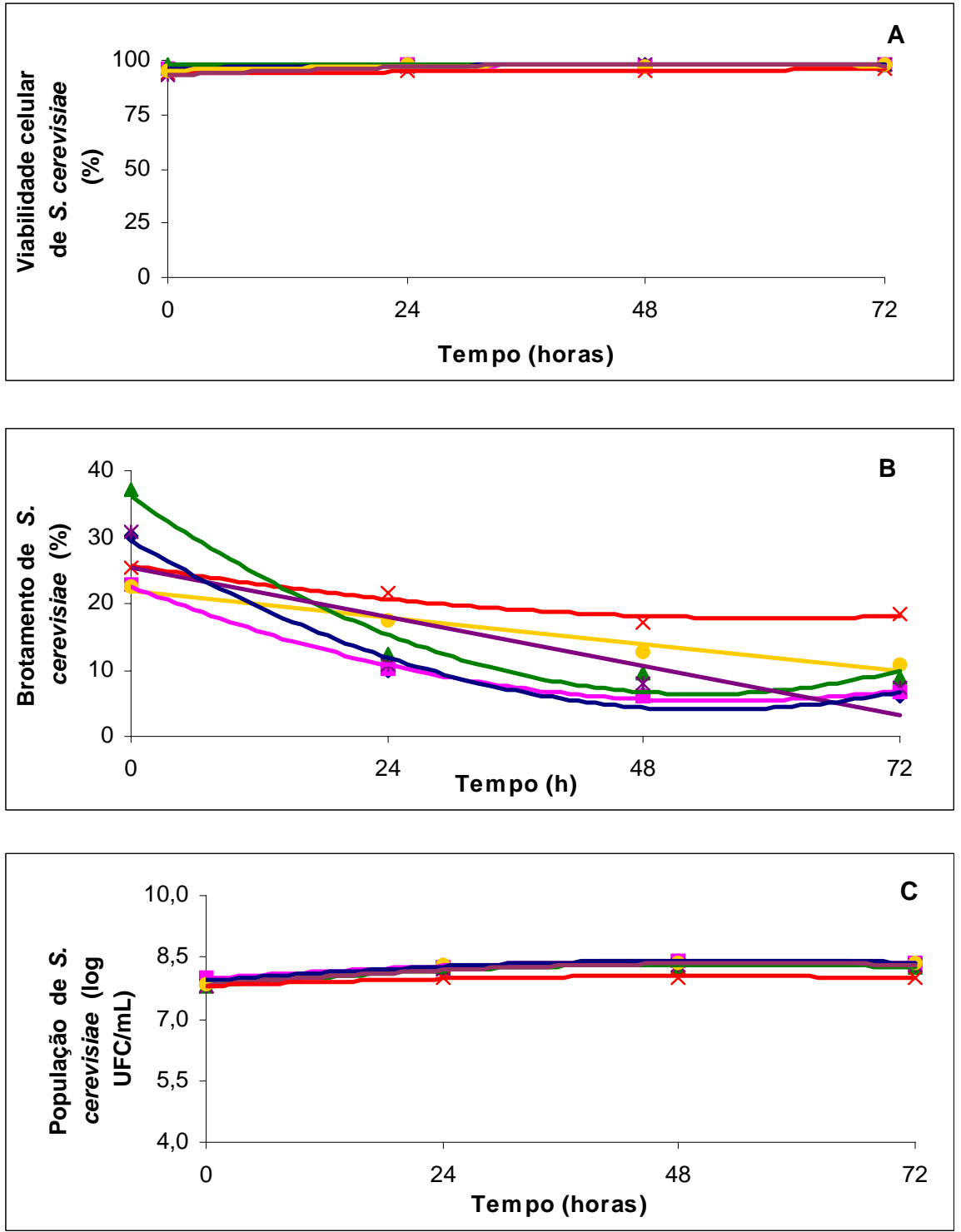

Figura 10 - Variações das determinações microbiológicas: viabilidade celular (A), Taxa de brotamento (B) e população de células (C) de S. cerevisiae; durante o cultivo misto de $S$. cerevisia com as bactérias tratadas pelo calor úmido: $B$. stearothermophilus $(\bullet)$, B. coagulans $(\square)$, B. subtilis $(\bullet)$, L. fermentum (x), L. plantarum (*); e o controle $(O$ ) refere-se de $S$. cerevisiae cultivada sem a presença de bactérias 

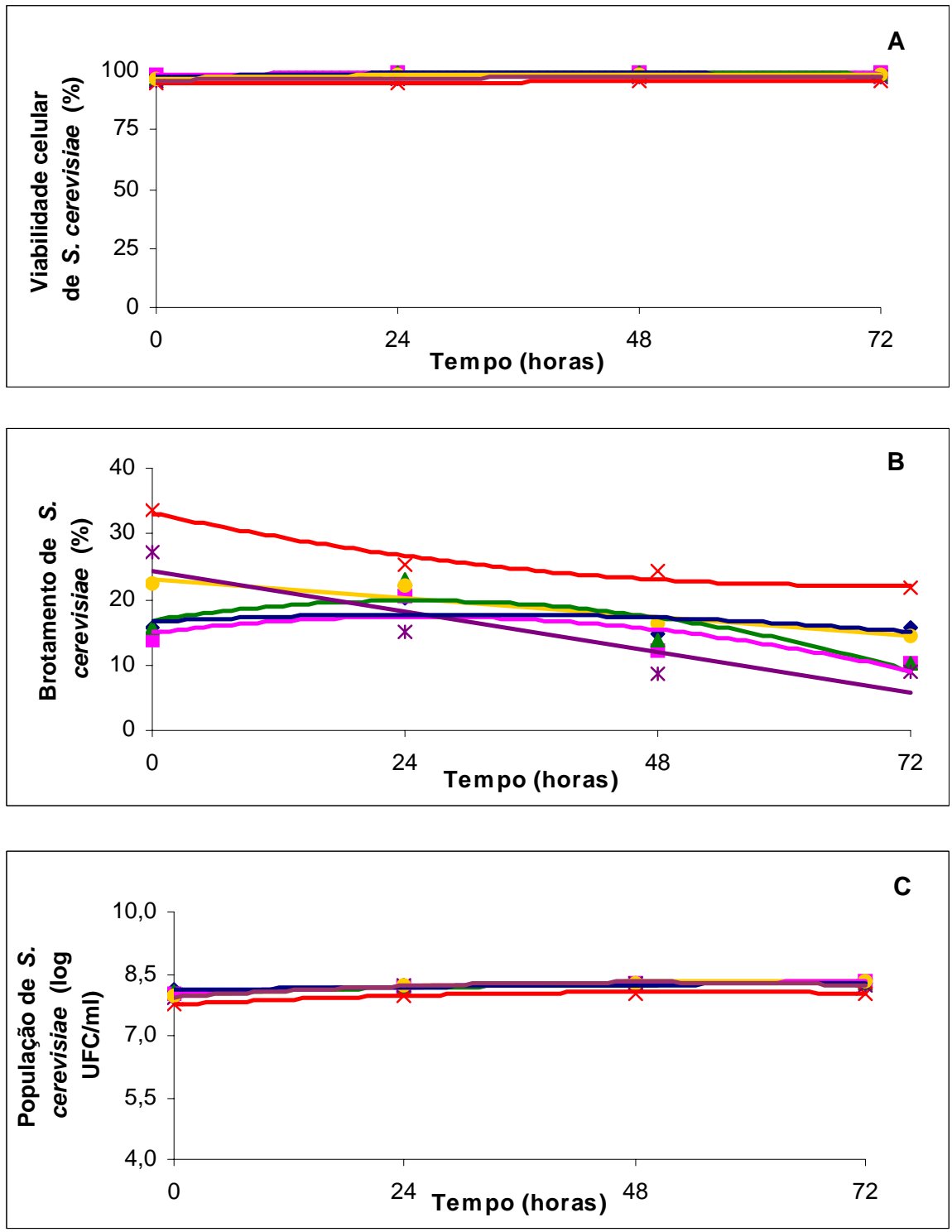

Figura 11 - Variações das determinações microbiológicas: viabilidade celular (A), Taxa de brotamento (B) e população de células (C) de S. cerevisiae; durante o cultivo misto de $S$. cerevisia com as bactérias tratadas pelo antimicrobiano Kamoran $\mathrm{HJ}$ : B. stearothermophilus $(\diamond), B$. coagulans $(\square)$, B. subtilis $(\Delta)$, L. fermentum $(X)$, L. plantarum (*); e o controle $(\bigcirc)$ refere-se de S. cerevisiae cultivada sem a presença de bactérias 

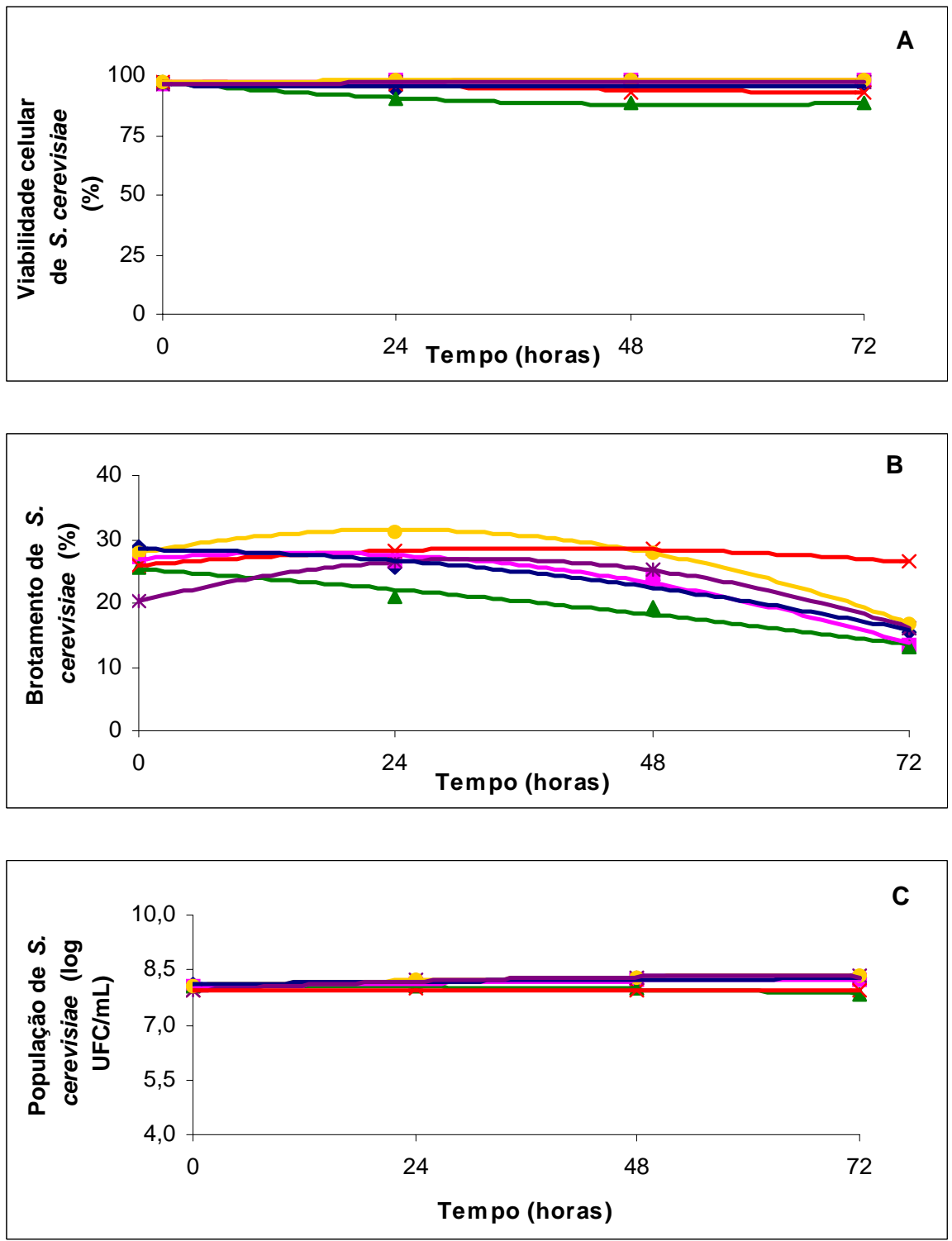

Figura 12 - Variações das determinações microbiológicas: viabilidade celular (A), Taxa de brotamento (B) e população de células (C) de $S$. cerevisiae; durante o cultivo misto de $S$. cerevisia com as bactérias tratadas com irradiação: $B$. stearothermophilus $(\bullet), B$. coagulans $(\square)$, B. subtilis $(\bullet)$, L. fermentum $(\mathbf{X}), L$. plantarum (*); e o controle ( ) refere-se de S. cerevisiae cultivada sem a presença de bactérias 
Os resultados da viabilidade celular de S. cerevisiae (Tabela 22 e 23) não apresentaram diferenças significativas na interação entre microrganismos e períodos. No controle e em todos os cultivos mistos de $S$. cerevisiae e bactérias tratadas com calor úmido ou Kamoran $\mathrm{HJ}$ a viabilidade manteve-se estável.

A única bactéria tratada por radiação gama que interferiu na viabilidade celular de $S$. cerevisiae foi $B$. subtilis, que reduziu a viabilidade das leveduras em $9 \%$ trazendo-a para 88,5\% (Tabela 24). Isto sugere que a população remanescente da bactéria, após a irradiação, pode ter trazido consigo no meio de cultura substâncias capazes de reduzir ou inibir, de alguma maneira, o desenvolvimento de S. cerevisiae.

A viabilidade celular de $S$. cerevisiae nos cultivos mistos com $B$. stearothermophilus ou $L$. fermentum tratadas com radiação gama diferiram estatisticamente do controle (Tabela 24) porém em menor intensidade que no cultivo misto com $B$. subtilis. Em realidade, apesar de diferenças estatísticas, a viabilidade celular de $S$. cerevisiae em condições de carência nutricional e em sobrevivência com outros microrganismos precisa ser mais intensivamente investigada para se isolar as variáveis atuantes no fenômeno.

Tabela 22. Teste de Tukey para as médias de viabilidade celular de $\mathbf{S}$. cerevisiae, comparando os microrganismos e os períodos, em cultura mista de $S$. cerevisiae e bactérias tratadas com calor

\begin{tabular}{|c|c|c|c|c|c|c|}
\hline \multirow{3}{*}{$\begin{array}{c}\text { Períodos } \\
\text { (horas) }\end{array}$} & \multicolumn{5}{|c|}{ Cultivo misto de S. cerevisiae com } & \multirow{2}{*}{$\begin{array}{l}\text { S. cerevisiae } \\
\text { (controle) }\end{array}$} \\
\hline & $\begin{array}{c}\text { Bacillus } \\
\text { stearothermophilus }\end{array}$ & $\begin{array}{l}\text { Bacillus } \\
\text { subtilis }\end{array}$ & $\begin{array}{l}\text { Bacillus } \\
\text { coagulans }\end{array}$ & $\begin{array}{l}\text { Lactobac. } \\
\text { plantarum }\end{array}$ & $\begin{array}{l}\text { Lactobac. } \\
\text { fermentum }\end{array}$ & \\
\hline & \multicolumn{6}{|c|}{ Viabilidade celular de S. cerevisiae (\%) } \\
\hline 0 & $96,20 \mathrm{Aa}$ & $97,68 \mathrm{Aa}$ & $96,35 \mathrm{Aa}$ & $93,50 \mathrm{Aa}$ & $93,75 \mathrm{Aa}$ & $95,30 \mathrm{Aa}$ \\
\hline 24 & $97,65 \mathrm{Aa}$ & $98,25 \mathrm{Aa}$ & $98,25 \mathrm{Aa}$ & $97,45 \mathrm{Aa}$ & $94,95 \mathrm{Aa}$ & $97,70 \mathrm{Aa}$ \\
\hline 48 & $97,70 \mathrm{Aa}$ & $97,95 \mathrm{Aa}$ & $97,30 \mathrm{Aa}$ & $97,40 \mathrm{Aa}$ & $95,15 \mathrm{Aa}$ & $97,55 \mathrm{Aa}$ \\
\hline 72 & $98,10 \mathrm{Aa}$ & $98,20 \mathrm{Aa}$ & $98,30 \mathrm{Aa}$ & $97,95 \mathrm{Aa}$ & $95,70 \mathrm{Aa}$ & $97,45 \mathrm{Aa}$ \\
\hline
\end{tabular}

Obs.: Médias seguidas pelas mesmas letras, minúsculas nas linhas e maiúsculas nas colunas, não diferem entre si de acordo com o teste de Tukey ao nível de $1 \%$ de significância 
Tabela 23. Teste de Tukey para as médias de viabilidade celular de $\mathbf{S}$. cerevisiae, comparando os microrganismos e os períodos, em cultura mista de $S$. cerevisiae e bactérias tratadas com Kamoran $\mathrm{HJ}$

\begin{tabular}{|c|c|c|c|c|c|c|}
\hline \multirow{3}{*}{$\begin{array}{c}\text { Períodos } \\
\text { (horas) }\end{array}$} & \multicolumn{5}{|c|}{ Cultivo misto de S. cerevisiae com } & \multirow{2}{*}{$\begin{array}{l}\text { S. cerevisiae } \\
\text { (controle) }\end{array}$} \\
\hline & $\begin{array}{c}\text { Bacillus } \\
\text { stearothermophilus }\end{array}$ & $\begin{array}{l}\text { Bacillus } \\
\text { subtilis }\end{array}$ & $\begin{array}{c}\text { Bacillus } \\
\text { coagulans }\end{array}$ & $\begin{array}{l}\text { Lactobac. } \\
\text { plantarum }\end{array}$ & $\begin{array}{l}\text { Lactobac. } \\
\text { fermentum }\end{array}$ & \\
\hline & \multicolumn{6}{|c|}{ Viabilidade celular de S. cerevisiae (\%) } \\
\hline 0 & 96,90 Aa & $96,70 \mathrm{Aa}$ & $97,85 \mathrm{Aa}$ & $96,00 \mathrm{Aa}$ & $94,30 \mathrm{Aa}$ & $96,65 \mathrm{Aa}$ \\
\hline 24 & $98,85 \mathrm{Aab}$ & 98,70 Aac & $99,30 \mathrm{Aa}$ & $96,25 \mathrm{Aac}$ & $95,40 \mathrm{Abc}$ & 98,15 Aac \\
\hline 48 & $98,75 \mathrm{Aab}$ & $99,40 \mathrm{Ab}$ & $99,15 \mathrm{Aab}$ & $97,55 \mathrm{Aab}$ & $95,60 \mathrm{Aa}$ & $98,40 \mathrm{Aab}$ \\
\hline 72 & $97,50 \mathrm{Aa}$ & $98,45 \mathrm{Aa}$ & $98,80 \mathrm{Aa}$ & $97,35 \mathrm{Aa}$ & $95,40 \mathrm{Aa}$ & $98,35 \mathrm{Aa}$ \\
\hline
\end{tabular}

Obs.: Médias seguidas pelas mesmas letras, minúsculas nas linhas e maiúsculas nas colunas, não diferem entre si de acordo com o teste de Tukey ao nível de 1 \% de significância

Tabela 24. Teste de Tukey para as médias de viabilidade celular de S. cerevisiae, comparando os microrganismos e os períodos, em cultura mista de $S$. cerevisiae e bactérias tratadas com irradiação

\begin{tabular}{|c|c|c|c|c|c|c|}
\hline \multirow{3}{*}{$\begin{array}{c}\text { Períodos } \\
\text { (horas) }\end{array}$} & \multicolumn{5}{|c|}{ Cultivo misto de S. cerevisiae com } & \multirow{2}{*}{$\begin{array}{l}\text { S. cerevisiae } \\
\text { (controle) }\end{array}$} \\
\hline & $\begin{array}{c}\text { Bacillus } \\
\text { stearothermophilus }\end{array}$ & $\begin{array}{l}\text { Bacillus } \\
\text { subtilis }\end{array}$ & $\begin{array}{c}\text { Bacillus } \\
\text { coagulans }\end{array}$ & $\begin{array}{l}\text { Lactobac. } \\
\text { plantarum }\end{array}$ & $\begin{array}{l}\text { Lactobac. } \\
\text { fermentum }\end{array}$ & \\
\hline & \multicolumn{6}{|c|}{ Viabilidade celular de S. cerevisiae (\%) } \\
\hline 0 & $96,55 \mathrm{Aa}$ & $97,25 \mathrm{Ab}$ & $96,75 \mathrm{Aab}$ & $96,65 \mathrm{Aab}$ & $97,30 \mathrm{Ab}$ & $97,10 \mathrm{Aab}$ \\
\hline 24 & $94,10 \mathrm{Bb}$ & $90,35 \mathrm{Bd}$ & 97,95 Bae & $97,30 \mathrm{ABa}$ & $96,45 \mathrm{Bc}$ & $98,35 \mathrm{Bc}$ \\
\hline 48 & $96,35 \mathrm{Ab}$ & $88,40 \mathrm{Ce}$ & $98,05 \mathrm{Ba}$ & $97,10 \mathrm{ABd}$ & $93,45 \mathrm{Cc}$ & $98,15 \mathrm{Ba}$ \\
\hline 72 & $95,50 \mathrm{Cb}$ & $88,50 \mathrm{Ce}$ & $98,60 \mathrm{Ba}$ & $97,65 \mathrm{Bd}$ & $92,90 \mathrm{Cc}$ & $98,20 \mathrm{Bad}$ \\
\hline
\end{tabular}

Obs.: Médias seguidas pelas mesmas letras, minúsculas nas linhas e maiúsculas nas colunas, não diferem entre si de acordo com o teste de Tukey ao nível de 1 \% de significância

A taxa de brotamento de S. cerevisiae variou bastante entre os períodos e os microrganismos, porém apresentou o mesmo comportamento para a maioria dos cultivos mistos, diminuindo ao longo do período de incubação, principalmente após 48 h (Tabela 25, 26 e 27) quando possivelmente o substrato foi exaurido. Exceto, novamente, o cultivo misto de $S$. cerevisiae com $L$. fermentum tratado por qualquer um dos tratamentos, que apresentou as maiores taxas de brotamento e praticamente se manteve durante todos os ensaios.

A interpretação do percentual de brotação numa fermentação é particularmente difícil, porém pode ser interpretada da seguinte maneira: uma elevada porcentagem de brotamento superior a $25 \%$ revela provavelmente boa 
composição do mosto e condições favoráveis à fermentação; e um baixo percentual de brotação com alta viabilidade pode estar relacionado à composição do mosto e outros fatores ambientais (Harrison e Graham, 1970).

Segundo Carvalho (2001), a taxa de brotamento não apresentou tendência definida e não guarda necessariamente relação com o crescimento do fermento e nem com a viabilidade, pois, segundo o autor, esta é uma medida pontual e pode sofrer a crítica de que o broto demora mais ou não se desprende da célula mãe se a condição nutricional assim induzir.

Tabela 25. Teste de Tukey para as médias de taxa de brotamento de S. cerevisiae, comparando os microrganismos e os períodos, em cultura mista de $S$. cerevisiae e bactérias tratadas com calor

\begin{tabular}{c|c|c|c|c|c|c|}
\hline \multirow{2}{*}{$\begin{array}{c}\text { Períodos } \\
\text { (horas) }\end{array}$} & \begin{tabular}{c} 
Bacillus \\
\cline { 2 - 6 }
\end{tabular} & $\begin{array}{c}\text { Bacillus } \\
\text { subtilis }\end{array}$ & $\begin{array}{c}\text { Bacillus } \\
\text { coagulans }\end{array}$ & $\begin{array}{c}\text { Lactobac. } \\
\text { plantarum }\end{array}$ & $\begin{array}{c}\text { Lactobac. cerevisiae } \\
\text { fermentum }\end{array}$ & (controle) \\
\cline { 2 - 6 } & \multicolumn{7}{|c|}{ Taxa de brotamento de S. cerevisiae $\%$} \\
\hline 0 & $30,90 \mathrm{Abc}$ & $36,50 \mathrm{Acd}$ & $22,50 \mathrm{Aa}$ & $30,40 \mathrm{Abd}$ & $25,85 \mathrm{Aab}$ & $23,35 \mathrm{Aab}$ \\
\hline 24 & $9,60 \mathrm{Ba}$ & $11,55 \mathrm{Bae}$ & $10,75 \mathrm{Bac}$ & $10,60 \mathrm{Bad}$ & $22,00 \mathrm{ABbc}$ & $17,80 \mathrm{ABcde}$ \\
\hline 48 & $6,40 \mathrm{Ba}$ & $9,40 \mathrm{Ba}$ & $6,00 \mathrm{Ba}$ & $7,80 \mathrm{Ba}$ & $17,05 \mathrm{Bb}$ & $13,40 \mathrm{Bab}$ \\
\hline 72 & $6,05 \mathrm{Ba}$ & $9,15 \mathrm{Ba}$ & $6,45 \mathrm{Ba}$ & $7,20 \mathrm{Ba}$ & $18,35 \mathrm{ABb}$ & $11,45 \mathrm{Bab}$ \\
\hline
\end{tabular}

Obs.: Médias seguidas pelas mesmas letras, minúsculas nas linhas e maiúsculas nas colunas, não diferem entre si de acordo com o teste de Tukey ao nível de 1 \% de significância

Tabela 26. Teste de Tukey para as médias de taxa de brotamento de S. cerevisiae, comparando os microrganismos e os períodos, em cultura mista de $S$. cerevisiae e bactérias tratadas com Kamoran $\mathrm{HJ}$

\begin{tabular}{|c|c|c|c|c|c|c|}
\hline \multirow{3}{*}{$\begin{array}{c}\text { Períodos } \\
\text { (horas) }\end{array}$} & \multicolumn{5}{|c|}{ Cultivo misto de S. cerevisiae com } & \multirow{2}{*}{$\begin{array}{l}\text { S. cerevisiae } \\
\text { (controle) }\end{array}$} \\
\hline & $\begin{array}{c}\text { Bacillus } \\
\text { stearothermophilus }\end{array}$ & $\begin{array}{l}\text { Bacillus } \\
\text { subtilis }\end{array}$ & $\begin{array}{c}\text { Bacillus } \\
\text { coagulans }\end{array}$ & $\begin{array}{l}\text { Lactobac. } \\
\text { plantarum }\end{array}$ & $\begin{array}{l}\text { Lactobac. } \\
\text { fermentum }\end{array}$ & \\
\hline & \multicolumn{6}{|c|}{ Taxa de brotamento de S. cerevisiae (\%) } \\
\hline 0 & $15,75 \mathrm{Aa}$ & $15,60 \mathrm{ABa}$ & $12,75 \mathrm{ABa}$ & $27,15 \mathrm{Ab}$ & $33,55 \mathrm{Ab}$ & $22,25 \mathrm{Aa}$ \\
\hline 24 & 20,10 Aab & $22,20 \mathrm{Aab}$ & $20,20 \mathrm{Aa}$ & $15,05 \mathrm{Ba}$ & $25,30 \mathrm{ABb}$ & $22,05 \mathrm{Aab}$ \\
\hline 48 & $14,80 \mathrm{Aab}$ & $14,05 \mathrm{ABa}$ & $11,85 \mathrm{ABa}$ & $8,75 \mathrm{Ba}$ & $24,30 \mathrm{ABb}$ & $16,05 \mathrm{Aab}$ \\
\hline 72 & $15,85 \mathrm{Aab}$ & $10,60 \mathrm{Ba}$ & $10,00 \mathrm{Ba}$ & $8,90 \mathrm{Ba}$ & $21,75 \mathrm{Bb}$ & $14,10 \mathrm{Aab}$ \\
\hline
\end{tabular}

Obs.: Médias seguidas pelas mesmas letras, minúsculas nas linhas e maiúsculas nas colunas, não diferem entre si de acordo com o teste de Tukey ao nível de 1 \% de significância 
Tabela 27. Teste de Tukey para as médias de taxa de brotamento de $\mathbf{S}$. cerevisiae, comparando os microrganismos e os períodos, quando em cultura mista de $S$. cerevisiae e bactérias tratadas com irradiação

\begin{tabular}{|c|c|c|c|c|c|c|}
\hline \multirow{3}{*}{$\begin{array}{c}\text { Períodos } \\
\text { (horas) }\end{array}$} & \multicolumn{5}{|c|}{ Cultivo misto de S. cerevisiae com } & \multirow{2}{*}{$\begin{array}{l}\text { S. cerevisiae } \\
\text { (controle) }\end{array}$} \\
\hline & $\begin{array}{c}\text { Bacillus } \\
\text { stearothermophilus }\end{array}$ & $\begin{array}{l}\text { Bacillus } \\
\text { subtilis }\end{array}$ & $\begin{array}{c}\text { Bacillus } \\
\text { coagulans }\end{array}$ & $\begin{array}{l}\text { Lactobac. } \\
\text { plantarum }\end{array}$ & $\begin{array}{l}\text { Lactobac. } \\
\text { fermentum }\end{array}$ & \\
\hline & \multicolumn{6}{|c|}{ Taxa de brotamento de S. cerevisiae (\%) } \\
\hline 0 & $28,80 \mathrm{Ab}$ & $25,70 \mathrm{Ac}$ & $27,20 \mathrm{Aa}$ & $20,20 \mathrm{Ad}$ & $25,45 \mathrm{Ac}$ & $27,85 \mathrm{Aab}$ \\
\hline 24 & $25,50 \mathrm{Bac}$ & $21,00 \mathrm{Be}$ & $26,60 \mathrm{Aa}$ & $26,40 \mathrm{Bc}$ & $28,20 \mathrm{Bb}$ & $31,25 \mathrm{Bd}$ \\
\hline 48 & $23,60 \mathrm{Ca}$ & $19,30 \mathrm{Ce}$ & $24,00 \mathrm{Bad}$ & $25,20 \mathrm{Bd}$ & $28,40 \mathrm{Bb}$ & $28,05 \mathrm{Ab}$ \\
\hline 72 & $15,40 \mathrm{Db}$ & $13,20 \mathrm{Da}$ & $13,40 \mathrm{Ca}$ & $16,05 \mathrm{Cb}$ & $26,40 \mathrm{Ac}$ & $16,75 \mathrm{Cb}$ \\
\hline
\end{tabular}

Obs.: Médias seguidas pelas mesmas letras, minúsculas nas linhas e maiúsculas nas colunas, não diferem entre si de acordo com o teste de Tukey ao nível de 1 \% de significância

A população de células de $S$. cerevisiae quando em cultivo misto com bactérias tratadas com calor ou Kamoran $\mathrm{HJ}$ ou radiação gama (Tabelas 28, 29 e 30), apesar de mostrar-se diferente do controle em quase todos os períodos, apresentou valores próximos de UFC/mL. Observa-se que os valores diferem estatisticamente, porém têm pouco significado microbiológico e podem ser considerado semelhantes.

Tabela 28. Teste de Tukey para as médias de população de células de $\mathbf{S}$. cerevisiae, comparando os microrganismos e os períodos, em cultura mista de $S$. cerevisiae e bactérias tratadas com calor

\begin{tabular}{c|c|c|c|c|c|c}
\hline \multirow{2}{*}{$\begin{array}{c}\text { Períodos } \\
\text { (horas) }\end{array}$} & \multicolumn{6}{|c|}{$\begin{array}{c}\text { Sultivo misto de S. cerevisiae } \\
\text { (controle) }\end{array}$} \\
\cline { 2 - 6 } & $\begin{array}{c}\text { Bacillus } \\
\text { stearothermophilus }\end{array}$ & $\begin{array}{c}\text { Bacillus } \\
\text { subtilis }\end{array}$ & $\begin{array}{c}\text { Bacillus } \\
\text { coagulans }\end{array}$ & $\begin{array}{c}\text { Lactobac. } \\
\text { plantarum }\end{array}$ & $\begin{array}{c}\text { Lactobac. } \\
\text { fermentum }\end{array}$ & \\
\cline { 2 - 6 } & \multicolumn{5}{|c|}{ População de células de S. cerevisiae (log UFC/mL) } \\
\hline 0 & $7,922 \mathrm{Ab}$ & $7,781 \mathrm{Ac}$ & $7,982 \mathrm{Aa}$ & $7,814 \mathrm{Ad}$ & $7,782 \mathrm{Ac}$ & $7,826 \mathrm{Ae}$ \\
\hline 24 & $8,284 \mathrm{Bb}$ & $8,233 \mathrm{Bf}$ & $8,271 \mathrm{Ba}$ & $8,196 \mathrm{Bd}$ & $8,023 \mathrm{Bc}$ & $8,301 \mathrm{Be}$ \\
\hline 48 & $8,414 \mathrm{Ca}$ & $8,274 \mathrm{Ce}$ & $8,419 \mathrm{Ca}$ & $8,329 \mathrm{Cc}$ & $7,993 \mathrm{Cb}$ & $8,385 \mathrm{Cd}$ \\
\hline 72 & $8,366 \mathrm{Db}$ & $8,263 \mathrm{Df}$ & $8,347 \mathrm{Da}$ & $8,315 \mathrm{Dd}$ & $8,003 \mathrm{Cc}$ & $8,377 \mathrm{Ce}$ \\
\hline
\end{tabular}

Obs.: Médias seguidas pelas mesmas letras, minúsculas nas linhas e maiúsculas nas colunas, não diferem entre si de acordo com o teste de Tukey ao nível de $1 \%$ de significância 
Tabela 29. Teste de Tukey para as médias de população de células de S. cerevisiae, comparando os microrganismos e os períodos, em cultura mista de $S$. cerevisiae e bactérias tratadas com Kamoran $\mathrm{HJ}$

\begin{tabular}{|c|c|c|c|c|c|c|}
\hline \multirow{3}{*}{$\begin{array}{c}\text { Períodos } \\
\text { (horas) }\end{array}$} & \multicolumn{5}{|c|}{ Cultivo misto de S. cerevisiae com } & \multirow{2}{*}{$\begin{array}{l}\text { S. cerevisiae } \\
\text { (controle) }\end{array}$} \\
\hline & $\begin{array}{c}\text { Bacillus } \\
\text { stearothermophilus }\end{array}$ & $\begin{array}{l}\text { Bacillus } \\
\text { subtilis }\end{array}$ & $\begin{array}{c}\text { Bacillus } \\
\text { coagulans }\end{array}$ & $\begin{array}{l}\text { Lactobac. } \\
\text { plantarum }\end{array}$ & $\begin{array}{l}\text { Lactobac. } \\
\text { fermentum }\end{array}$ & \\
\hline & \multicolumn{6}{|c|}{ População de células de S. cerevisiae (log UFC/mL) } \\
\hline$\overline{0}$ & $8,102 \mathrm{Ab}$ & $8,044 \mathrm{Af}$ & $8,029 \mathrm{Aa}$ & $7,929 \mathrm{Ad}$ & $7,757 \mathrm{Ac}$ & $7,976 \mathrm{Ae}$ \\
\hline 24 & $8,204 \mathrm{Bad}$ & $8,129 \mathrm{Be}$ & $8,194 \mathrm{Ba}$ & $8,231 \mathrm{Bc}$ & $7,982 \mathrm{Bb}$ & $8,211 \mathrm{Bd}$ \\
\hline 48 & $8,211 \mathrm{Bb}$ & $8,275 \mathrm{Ced}$ & $8,261 \mathrm{Ca}$ & $8,270 \mathrm{Cad}$ & $8,042 \mathrm{Cc}$ & $8,273 \mathrm{Cd}$ \\
\hline 72 & $8,274 \mathrm{Cb}$ & $8,254 \mathrm{Df}$ & $8,302 \mathrm{Da}$ & $8,227 \mathrm{Bd}$ & $8,029 \mathrm{Dc}$ & $8,342 \mathrm{De}$ \\
\hline
\end{tabular}

Obs.: Médias seguidas pelas mesmas letras, minúsculas nas linhas e maiúsculas nas colunas, não diferem entre si de acordo com o teste de Tukey ao nível de 1 \% de significância

Tabela 30. Teste de Tukey para as médias de população de células de S. cerevisiae, comparando os microrganismos e os períodos, em cultura mista de $S$. cerevisiae e bactérias tratadas com irradiação

\begin{tabular}{|c|c|c|c|c|c|c|}
\hline \multirow{3}{*}{$\begin{array}{c}\text { Períodos } \\
\text { (horas) }\end{array}$} & \multicolumn{5}{|c|}{ Cultivo misto de S. cerevisiae com } & \multirow{2}{*}{$\begin{array}{l}\text { S. cerevisiae } \\
\text { (controle) }\end{array}$} \\
\hline & $\begin{array}{c}\text { Bacillus } \\
\text { stearothermophilus }\end{array}$ & $\begin{array}{l}\text { Bacillus } \\
\text { subtilis }\end{array}$ & $\begin{array}{c}\text { Bacillus } \\
\text { coagulans }\end{array}$ & $\begin{array}{l}\text { Lactobac. } \\
\text { plantarum }\end{array}$ & $\begin{array}{l}\text { Lactobac. } \\
\text { fermentum }\end{array}$ & \\
\hline & \multicolumn{6}{|c|}{ População de células de S. cerevisiae $(\log$ UFC $/ \mathrm{mL})$} \\
\hline 0 & $8,103 \mathrm{Ab}$ & $8,044 \mathrm{Af}$ & $8,029 \mathrm{Aa}$ & $7,927 \mathrm{Ad}$ & $7,955 \mathrm{Ac}$ & $8,074 \mathrm{Ae}$ \\
\hline 24 & $8,202 \mathrm{Bb}$ & 8,03 & 8,12 & 8,2 & $7,982 \mathrm{Bc}$ & $\mathrm{Bd}$ \\
\hline 48 & $8,212 \mathrm{Ca}$ & & 8,20 & 8,2 & $7,942 \mathrm{Cb}$ & $\mathrm{Cd}$ \\
\hline 72 & $8,275 \mathrm{Db}$ & $7,856 \mathrm{Df}$ & $8,232 \mathrm{Da}$ & $8,329 \mathrm{Dd}$ & $7,929 \mathrm{Dc}$ & $8,360 \mathrm{De}$ \\
\hline
\end{tabular}

Obs.: Médias seguidas pelas mesmas letras, minúsculas nas linhas e maiúsculas nas colunas, não diferem entre si de acordo com o teste de Tukey ao nível de 1 \% de significância

O objetivo dos diferentes tratamentos empregados neste trabalho foi verificar a influência dos produtos metabólicos das culturas isoladas de bactérias sobre a viabilidade celular de $S$. cerevisiae, contudo o que foi observado na maioria dos cultivos mistos de $S$. cerevisiae tanto com bactérias ativas ou tratadas por qualquer um dos tratamentos foi que as bactérias, nestas condições de cultivo, pouco produziram ácidos, com exceção de L. fermentum.

O único tratamento capaz de inativar $100 \%$ das bactérias em estudo foi 0 calor úmido e, para este tratamento, observou-se que a viabilidade de $S$. cerevisiae não foi afetada durante o ensaio; estes resultados indicaram que a 
presença dos metabólitos celulares dessas bactérias não foi suficiente para reduzir a porcentagem de células vivas de S. cerevisiae.

Apenas as bactérias $B$. subtilis, $L$. fermentum e B. stearothermophilus tratadas com irradiação em cultivo misto com S. cerevisiae, causaram redução na viabilidade celular de S. cerevisiae (Figura 12A). B. subtilis, L. fermentum e $B$. stearothermophilus tratadas com calor ou antimicrobiano e as demais bactérias (B. coagulans e L. plantarum) tratadas pelos diferentes processos (calor, irradiação e antimicrobiano) não afetaram a viabilidade celular de $S$. cerevisiae (Figuras 10A e 11A).

O comportamento de $L$. fermentum e B. stearothermophilus tratados com irradiação em cultivo misto com S. cerevisiae foi minuciosamente observado, pois a queda da viabilidade foi baixa, quase que insignificante, indicando que a redução pode ter sido mais induzida pela exaustão de substrato do que pela associação com os metabólicos das bactérias.

Vale ressaltar o comportamento da bactéria $B$. subtilis tratada pela radiação gama. Observa-se que a viabilidade celular (Figura 12A) e a população de células (Figura 12C) de S. cerevisiae cultivada nesse meio diminuíram durante o período de incubação. Isto aconteceu porque o tratamento utilizado, de 15 kGy de radiação gama, não foi suficiente para inativar completamente a cultura dessa bactéria (Tabela 10). Assim, as células remanescentes da bactéria $B$. subtilis (Tabela 12) reduziram a porcentagem de células vivas e a população de células de S. cerevisiae (Figuras 12A e 12C), conforme observado no tratamento com a bactéria ativa (Figuras 6A e 6C), porém em menor intensidade provavelmente devido à menor densidade populacional da bactéria no meio irradiado.

Estes resultados, mais uma vez, indicaram que a presença isolada dos metabólitos celulares dessas bactérias não foi suficiente para reduzir a porcentagem de células vivas de S. cerevisiae. Este ponto de vista também é discutido por Bayrock e Ingledew (2004), que atribuíram a redução de 83\% da 
viabilidade de S. cerevisiae à competição por nutrientes do substrato do que pelo ácido lático formado por L. paracasei.

\subsection{Comparação dos meios de cultivos convencionais e alternativo MCC- agar}

Para todos os microrganismos, as contagens obtidas com o cultivo em meio à base de caldo de cana foram semelhantes às obtidas nos meios convencionais (Tabela 31). O meio de cultivo à base de caldo de cana proporcionou contagens semelhantes provavelmente porque simula a composição do mosto de caldo de cana-de-açúcar, meio a partir do qual as bactérias foram isoladas do processo industrial de produção de etanol.

Horii (1983) também utilizou um meio de cultivo constituído de caldo de cana-de-açúcar clarificado, diluído a $8^{\circ}$ brix e suplementado com extrato de levedura e actidiona para isolamento e contagem de bactérias lácticas contaminantes da fermentação alcoólica. Freguglia (1997) obteve resultados semelhantes de crescimento de colônias de $L$. fermentum em meio de caldo de cana suplementado com extrato de levedura e peptona e em meio MRS-agar.

Segundo Rosales et al. (1987), para a preparação de um meio indefinido, o caldo decantado apresenta-se ideal pela sua concentração de açúcares, porém sua composição está sujeita a muitas variações ligadas ao setor agrícola e industrial, e a formulação a partir deles terá sempre uma composição bastante variável, o que pode conferir uma inadequada reprodutividade. Por esta razão, o meio preparado com caldo, embora seja rico em traços nutritivos, deve ser suplementado com outros elementos que lhe garantam estabilidade em parte de sua composição. 
Tabela 31. Comparação dos meios de cultivo convencionais e alternativo (MCCagar) na contagem microbiológica no início (0 h) e ao final (72 h) do período de incubação das culturas mista de bactéria e levedura

\begin{tabular}{lcc|cc}
\hline & \multicolumn{3}{c}{ CONTAGEM MICROBIOLÓGICA (UFC/mL)* } \\
\hline \multirow{2}{*}{ MICRORGANISMO } & \multicolumn{2}{c}{ INICIAL $(0 \mathrm{~h})^{\star}$} & \multicolumn{2}{c}{ FINAL $(72 \mathrm{~h})^{\star}$} \\
\cline { 2 - 5 } & $\begin{array}{c}\text { Meio } \\
\text { convencional* }\end{array}$ & $\begin{array}{c}\text { Meio } \\
\text { alternativo* }\end{array}$ & $\begin{array}{c}\text { Meio } \\
\text { convencional * }\end{array}$ & $\begin{array}{c}\text { Meio } \\
\text { alternativo* }\end{array}$ \\
\hline B. stearothermophilus & $6,7 \times 10^{8} \mathrm{a}$ & $8,6 \times 10^{8} \mathrm{~b}$ & $3,4 \times 10^{8} \mathrm{a}$ & $2,7 \times 10^{8} \mathrm{~b}$ \\
B. coagulans & $1,2 \times 10^{7} \mathrm{a}$ & $1,3 \times 10^{7} \mathrm{~b}$ & $8,4 \times 10^{7} \mathrm{a}$ & $7,0 \times 10^{7} \mathrm{~b}$ \\
B. subtilis & $4,8 \times 10^{7} \mathrm{a}$ & $3,9 \times 10^{7} \mathrm{~b}$ & $7,7 \times 10^{8} \mathrm{a}$ & $4,9 \times 10^{8} \mathrm{~b}$ \\
L. fermentum & $8,6 \times 10^{6} \mathrm{a}$ & $2,8 \times 10^{7} \mathrm{~b}$ & $1,0 \times 10^{7} \mathrm{a}$ & $2,8 \times 10^{7} \mathrm{~b}$ \\
L. plantarum & $2,8 \times 10^{6} \mathrm{a}$ & $5,3 \times 10^{6} \mathrm{~b}$ & $6,3 \times 10^{6} \mathrm{a}$ & $7,8 \times 10^{6} \mathrm{~b}$ \\
S. cerevisiae & $4,5 \times 10^{7} \mathrm{a}$ & $4,1 \times 10^{7} \mathrm{~b}$ & $4,4 \times 10^{8} \mathrm{a}$ & $3,7 \times 10^{8} \mathrm{~b}$ \\
\hline
\end{tabular}

* Média de 18 plaqueamentos

* Inicial $(0 \mathrm{~h})=$ início do período de incubação das culturas mistas de bactérias e leveduras

* Final $(72 \mathrm{~h})=$ final do período de cultivo misto

* Meio convencional = PCA para bactérias do gênero Bacillus, MRSA para bactérias do gênero Lactobacillus e YEPDA para a levedura S. cerevisiae

* Meio alternativo = MCC-agar

Obs.: Médias seguidas pelas mesmas letras nas linhas não diferem entre si de acordo com o teste de Tukey ao nível de $1 \%$ de significância

A análise dos resultados (Tabela 31) obtidos nos plaqueamentos evidencia que os dois meios de cultivos possibilitaram a obtenção de resultados similares aceitáveis do ponto de vista microbiológico, porém diferentes estatisticamente.

Embora tenha surgido essa diferença estatística detectada pelo teste de Tukey, a metodologia de plaqueamento, precedido pela alta diluição seriada, conduz as diferenças encontradas. Em termos de UFC/mL, fica claro que esses meios são similares pois se fossem específicos teríamos sempre uma tendência clara de preferência. 


\section{CONCLUSÕES}

- Das bactérias ativas testadas, somente L. fermentum e B. subtilis reduziram a viabilidade celular de $S$. cerevisiae em cultivo misto.

- As bactérias L. plantarum, B. coagulans e B. stearothermophilus e/ou seus produtos metabólicos não influenciaram a viabilidade celular da levedura, nestas condições de cultivo.

- A presença isolada dos metabólitos celulares de todas as bactérias não foram suficientes para reduzir as porcentagens de células vivas de $S$. cerevisiae.

- A acidez do meio juntamente com a presença das bactérias foram os principais fatores relacionados à redução da viabilidade celular de $S$. cerevisiae.

- O meio de cultivo à base de caldo de cana-de-açúcar a $5^{\circ}$ brix suplementado com 1\% de extrato de levedura e peptona pôde substituir os meios tradicionais para o cultivo da levedura e das bactérias testadas. 


\section{REFERÊNCIAS BIBLIOGRÁFICAS}

ALCARDE, A.R. Efeito da radiação gama em alguns parâmetros microbiológicos e bioquímicos da fermentação alcoólica. Piracicaba, 2000. 111p. Tese (Doutorado) - Centro de Energia Nuclear na Agricultura, Universidade de São Paulo.

ALCARDE, A.R.; WALDER, J.M.M.; HORII, J. Fermentation of irradiated sugarcane must. Scientia Agricola, v.60, n.4, p.677-681, 2003.

ALCARDE, V.E. Avaliação de antimicrobianos em germinação de esporos e na multiplicação de bactérias isoladas de processos de fermentação alcoólica. Piracicaba, 1995. 114p. Dissertação (Mestrado) - Escola Superior de Agricultura "Luiz de Queiroz", Universidade de São Paulo.

ALCARDE, V.E.; YOKOYA, F. Efeito da população de bactérias na floculação de leveduras isoladas de processos industriais de fermentação alcoólica. STAB. Açúcar, Álcool e Subprodutos, v.21, n.4, p.40-43, 2003.

ALEXANDER, M. Microbial ecology. London: John Wiley \& Sons, 1971. 511p.

ALTERTHUM, F.; CRUZ, M.R.M.; VAIRO, M.L.R.; GAMBASSI, D.M. Efeito dos microrganismos contaminantes da fermentação alcoólica nas microdestilarias. STAB. Açúcar, Álcool e Subprodutos, v.3, n.1, p.42-49, 1984. 
ALVES, D.M.G. Fatores que afetam a formação de ácidos orgânicos bem como outros parâmetros da fermentação alcoólica. Piracicaba, 1994. 274p. Dissertação (Mestrado) - Escola Superior de Agricultura "Luiz de Queiroz", Universidade de São Paulo.

ALVES, D.M.G. Respostas fisiológicas de duas linhagens de Saccharomyces cerevisiae frente ao potássio durante a fermentação alcoólica. Rio Claro, 2000. 118p. Tese (Doutorado) - Instituto de Biociências de Rio Claro, Universidade Estadual Paulista "Júlio de Mesquita Filho".

AMERINE, M.A.; OUGH, C.S. Wine and must analysis. London: John Wiley \& Sons, 1974. 121p.

AMORIM, H.V.; OLIVEIRA, A.J.; CAMPOS, H. Infecção, problema sério na produção de álcool. In: CONGRESSO NACIONAL DA SOCIEDADE DOS TÉCNICOS AÇUCAREIROS DO BRASIL, 2., Rio de Janeiro, 1981. Anais. Piracicaba: STAB, 1981. p.158-168.

AMORIM, H.V.; OLIVEIRA, A.J. Infecção na fermentação: como evitá-la. Álcool e Açúcar, v.2, n.5, p.12-18, 1982.

BAYROCK D.; INGLEDEW, W.M. Changes In steady state on introduction of a Lactobacillus contaminat to a continuous culture ethanol fermentation. Journal of Microbiology \& Biotechnology, v.27, p.39-45, 2001.

BAYROCK D.; INGLEDEW, W.M. Inhibition of yeast by lactic acid bacteria In continuos culture: nutrient depletion and/or acid toxicity? Journal of Industrial Microbiology \& Biotechnology, v.31, n.8, p.362-368, 2004. 
BAYROCK D.; INGLEDEW, W.M. Ethanol production in multistage continuous, single stage continuous, Lactobacillus-contaminated continuous, and batch fermentations. World Journal of Microbiology \& Biotechnology, v.21, p.8388, 2005.

BEVAN, D.; BOND, J. Microorganism in field and mill - a preliminary survey. In: CONFERENCE OF THE QUEENSLAND SOCIETY OF SUGAR CANE TECHNOLOGISTS, 38., Cairns, 1971. Proceedings. Brisbane: Watson Fergunson, 1971. p.137-143.

CARVALHO, R.S. Interação entre leveduras e bactérias durante a fermentação alcoólica. Piracicaba, 2001. 74p. Dissertação (Mestrado) - Escola Superior de Agricultura "Luiz de Queiroz", Universidade de São Paulo.

CASAL, M.; CARDOSO, H.; LEAO, C. Mechanisms regulating the transport of acetic acid in Sacharomyces cerevisiae. Microbiology-UK, v.142, p.13851390, 1996.

CHERUBIN, R.A. Efeito da viabilidade da levedura e da contaminação bacteriana na fermentação alcoólica. Piracicaba, 2003. 124p. Dissertação (Doutorado) - Escola Superior de Agricultura "Luiz de Queiroz", Universidade de São Paulo.

CHESTER, V.E. Endogenous metabolism of freshly harvested cells of a brewer's yeast. Nature, v.183, n.4665, p.902-903, 1959.

CHIN, P.M.; INGLEDEW, W.M. Effect of lactic acid bacteria on wheat mash fermentation prepared with laboratory backset. Enzime Microbiology and Technology, v.16, n.4, p.311-317, 1994. 
CONTROLE microbiológico da usina de açúcar e álcool. Boletim Técnico Copersucar, n.22, p.2-17, maio, 1983.

CONWAY, E.J.; DOWNEY, M. pH values of the yeast cell. Biochemical Journal, v.47, n.2, p.355-360, 1950.

CRUZ, S.H. Efeito da natureza da fonte de nitrogênio no fluxo metabólico do carbono em microrganismos: estudo enzimático e fisiológicos com leveduras Crabtree positivo e negativo. Araraquara, 2002. 133p. Tese (Doutorado) - Instituto de Química, Universidade Estadual Paulista "Júlio de Mesquita Filho".

EGUCHI, S.Y.; YOKOYA, F.; CANHOS, V.P.; GALLO, C.R. Pontos críticos microbiológicos em usinas de açúcar e álcool. Campinas: Fundação tropical de Pesquisas e Tecnologia "André Tosello", 1989. 78p.

ESSIA-NGANG, T.J.E.; LETOURNEAU, F.; VILLA, P. Alcoholic fermentation of beet molasses: effects of lactic acid on yeast fermentation parameters. Applied Microbiology and Biotechnology, v.31, p.125-128, 1989.

FREGUGLIA, R.M.O. Viabilidade celular de Saccharomyces cerevisiae em cultura mista com Lactobacillus fermentum. Piracicaba, 1997. 104p. Dissertação (Mestrado) - Escola Superior de Agricultura "Luiz de Queiroz", Universidade de São Paulo.

GALLO, C.R. Determinação da microbiota bacteriana de mosto e de dornas de fermentação alcoólica. Campinas, 1989. 388p. Tese (Doutorado) - Faculdade de Engenharia de Alimentos, Universidade de Campinas. 
GALLO, C.R.; CANHOS, V.P. Contaminates bacterianos na fermentação alcoólica - revisão. STAB. Açúcar, Álcool e Subprodutos, p.35-40, mar./jun. 1991.

GILLILAND, R.P.; LACEY, J.P. Lethal action by an Acetobacter on yeasts. Nature, v.202, p.727-728, 1964.

GOMES, E. Efeito do tratamento ácido da levedura Saccharomyces cerevisiae na fermentação alcoólica. Piracicaba, 1988. 206p. Dissertação (Mestrado) Escola Superior de Agricultura "Luiz de Queiroz", Universidade de São Paulo.

HARRISON, J.S.; GRAHAM, J.C.J. Yeast in distillery practice. In: ROSE, A.H.; HARRISON, J.S. (Ed.) The yeasts. London: Academic Press, 1970. v.3, cap.6, p. 283-348.

HORII, J. Isolamento e contagem de bactérias contaminantes do caldo de cana em meio de cana e PCA. In: SEMINÁRIO AGROINDUSTRIAL "LUIZ DE QUEIROZ", 2., Piracicaba, 1983.

HUANG, Y.C.; EDWARDS, C.G.; PETERSON, J.C.; HAAG, K.M. Relationship between sluggish fermentations and the antagonism of yeast by lactic acid bacteria. American Journal of Enology and Viticulture, v.47, p. 1-10, 1996.

IEMMA, J.; ALCARDE, A.R.; WALDER, J.M.M.; HORII, J. Comparação entre a Radiação Gama e Kamoran HJ na descontaminação do mosto de caldo de cana-de -açúcar. In: ENCONTRO CIENTÍFICO DOS PÓS-GRADUANDOS, 6., Piracicaba, 2000. Resumos. Piracicaba: CENA/USP, 2000.

INGLEDEW, W.M. The biochemistry of alcohol production In: LYONS, T.P.; KELSALL, D.R.; MURTAGH, J.E.(Ed.) The alcohol textbook. Nottingham: Nottingham University Press, 1995. p.55-79. 
KANEKO, T.; YAMAMOTO, Y. Killing of yeast by acid bacteria. Journal of the Institute of Brewing, v.74, n.5, p.476, 1968.

KHAN, A.R.; HOQ, M.M. Lactic acid bacteria as contaminant in alcohol fermentation. Bangladesh Journal of Microbiology, v.7, n.2, p.119-121, 1990.

KUNKEE, R.E.; AMERINE, M.A. Yeast In wine-making. In: ROSE, A.H.; HARRISON, J.S. (Ed.) The yeasts. London: Academic Press, 1970. v.3, cap.2, p. 6-71.

MAIORELLA, B.; BLANCH, H.W.; WILKE, C.H. By-product inhibition effects on ethanolic fermentation by Saccharomyces cerevisiae. Biotechnology and Bioengineering, v.25, p.103-121, 1983.

MAKANJUOLA, D.B.; TYMON, A.; SPRINGHAM, D.G. Some effects of lactic acid bacteria on laboratory-scale yeast fermentation. Enzime Microbiology and Technology, v.14, n.4, p.350-357, 1992.

NARENDRANATH, N.V.; POWER, R. Effect of yeast inoculation rate on the metabolism of contaminating lactocilli during fermentation of corn mash. Journal of Industrial Microbiology and Biotechnology, v.31, p.581-584, 2004

OLIVA-NETO, P. Influência da contaminação por bactérias láticas na fermentação alcoólica por batelada-alimentada. Campinas, 1990. 199p. Dissertação (Mestrado) - Faculdade de Engenharia de Alimentos, Universidade de Campinas. 
OLIVA-NETO, P; YOKOYA, F. Effects of nutritional factors on growth of Lactobacillus fermentum mixed with Saccharomyces cerevisiae in alcoholic fermentation. Revista de Microbiologia, v.28, n., p.25-31, 1997.

OLIVEIRA, A.J.; GALLO, C.R.; ALCARDE, V.E.; GODOY, A.; AMORIM, H.V. Métodos para o controle microbiológico na produção de álcool e açúcar. Piracicaba: FERMENTEC; FEALQ; ESALQ-USP, 1996. 89p.

PÁCA, J. Reserve carbohydrate metabolism and cell survival in aerobically starving baker's yeast. Journal of Institute of Brewing, v.87, p.147-150, 1981.

POSTMES, T.; BOGAARD, A.E.; HAZEN, M. The sterilization of honey with cobalt 60 gamma radiation: a study of honey spike with spores of Clostridium botulinum and Bacillus subtilis. Experientia, v.51, n.9, p.986-989, 1995.

PREGNOLATO, W.; PREGNOLATO, N.P. Normas analíticas do Instituto Adolfo Lutz: métodos químicos e físicos para a análise de alimentos. 3.ed. v.1. São Paulo, 1985. 533p.

RODINI, M.A.T. Isolamento, caracterização e identificação de bactérias contaminantes de dornas de fermentação nas destilarias de etanol. Piracicaba, 1985. 92p. Dissertação (Mestrado) - Escola Superior de Agricultura "Luiz de Queiroz", Universidade de São Paulo. 
ROSALES, S.Y.R.; ANGELIS, D.D.F.; FURLETTI, M.E.M.; VIOTTI, A.V. Propostas de meios de cultivo para dinamizar a identificação dos principais problemas microbiológicos da indústria alcooleira. In: Congresso Nacional da STAB, 4., Convenção da Associação Civil de Técnicos Açucareiros da América Latina e das Caraíbas, 5., São Paulo, 1984. Anais. São Paulo: STAB, 1987.

ROSALES, S.Y.R. Contaminantes bacterianos da fermentação etanólica: isolamento em meios diferenciais, identificação e avaliação de desinfetantes. Rio Claro, 1989. 200p. Tese (Doutorado) - Faculdade Estadual Paulista "Júlio de Mesquita Filho".

ROTHSTEIN, A.; BRUCE, M. The efflux of potassium from yeast cells into a potassium free medium. Journal Cellulary Comparative Physiology, v.51, n.3, p.439-455, 1958.

SAS Institute. SAS users guide: statistic. 6.ed. Cary: SAS Institute, 1990. $584 p$.

SEASTON, A.; CARR, G.; EDDY, A.A. The concentration of glycine by preparations of the yeast Saccharomyces carlsbergensis depleted of adenosine triphosphate: effects of proton gradients and uncoupling agents. Biochemical Journal, v.154, n.3, p.669-676, 1976.

SHIN, J.; PYUN, Y. Inactivation of Lactobacillus plantarum by pulsed-microwave irradiation. Journal of Foood Science, v.62, n.1, p.163-166, 1997.

SKINNER, K.A.; LEATHERS, T.D. Bacterial contaminants of fuel ethanol production. Journal of Industrial Microbiology and Biotechnology, v.31, p.401-408, 2004. 
SILVA, E. da. Estudo preliminar de controle da infecção de moendas através de bactericidas. In: Seminário Copersucar da Agroindústria Açucareira, 3., Águas de Lindóia, 1975. Anais. Piracicaba: Copersucar, 1975. p.473-483.

SILVA, N. Influência do resfriamento em torres sobre a microflora do caldo de cana no processo de produção de álcool. Campinas, 1988. 117p. Dissertação (Mestrado) - Faculdade de Engenharia de Alimentos, Universidade de Campinas.

SOLS, A.; GANCEDO, C.; DELAFUENTE G. Energy-yielding metabolism In yeast. In: ROSE, A.H.; HARRISON, J.S. (Ed.) The yeasts. London: Academic Press, 1971. v.2, cap.7, p. 271-307.

STUPIELLO, M.G. Avaliação de metodologia para estudo de alguns antimicrobianos frente às bactérias gram (+) isoladas da fermentação alcoólica. Piracicaba, 1993. 96p. Dissertação (Mestrado) - Escola Superior de Agricultura "Luiz de Queiroz", Universidade de São Paulo.

TANIWAKI, M.H. Meios de cultura para contagem de fungos em alimentos. Boletim da Sociedade Brasileira de Ciência e Tecnologia de Alimentos, v.30, n.2, p.132-141, 1996.

THOMAS, K.C.; HYNES, S.H.; INGLEDEW, W.M. Effect of lactobacilli on yeast growth, viability and batch and semi continuos alcoholic fermentation of corn mash. Journal of Applied Microbiology, v.90, p.819-828, 2001.

URBAIN, W.M. Food irradiation. Orlando: Academic Press, 1986. 351p.

YOKOYA, F. Problemas com contaminantes na fermentação alcoólica. STAB. Açúcar, Álcool e Subprodutos, v.9, n.6, p.38-39, 1991. 
YOKOYA, F. Microbiologia do processo de fermentação. In: EGUCHI, S.Y.; YOKOYA, F.; CANHOS, V.P.; GALLO, C.R. Pontos críticos microbiológicos em usinas de açúcar e álcool. Campinas: Fundação tropical de Pesquisas e Tecnologia “André Tosello”, 1989. p.1-22.

ZAGO, E.A.; SILVA, L.F.L.F.; BERNARDINO, C.D.; AMORIM, H.V. Métodos analíticos para o controle da produção de álcool e açúcar. 2.ed. Piracicaba: Fermentec, FEALQ, ESALQ-USP, 1996. p.59.

ZELLER, A.L.V.; OLIVEIRA, A.J.; ZAGO, E.A. Conservação de xarope de canade-açúcar pelo emprego da radiação gama. STAB. Açúcar, Álcool e Subprodutos, v.2, n.4, p.29-36, 1984. 
APÊNDICE 
Tabela 32. Resultados das determinações físico-químicas e microbiológicas do $1^{0}$ ensaio dos cultivos mistos de $S$. cerevisiae com bactérias ativas

\begin{tabular}{|c|c|c|c|c|c|c|c|c|}
\hline \multirow{3}{*}{\multicolumn{2}{|c|}{ Microrganismos }} & \multirow{3}{*}{ Períodos } & \multicolumn{3}{|c|}{ Determinações físico-químicas } & \multicolumn{3}{|c|}{ Determinações microbiológicas } \\
\hline & & & $\begin{array}{c}\text { Acidez } \\
\text { total }\end{array}$ & $\begin{array}{l}\text { Acidez } \\
\text { volátil }\end{array}$ & \multirow{2}{*}{$\begin{array}{c}\mathrm{pH} \\
- \\
\end{array}$} & $\begin{array}{c}\text { Viabilidade } \\
\text { celular }\end{array}$ & $\begin{array}{c}\text { Taxa de } \\
\text { Brotamento }\end{array}$ & \multirow{2}{*}{$\begin{array}{l}\text { População } \\
\text { de células } \\
\text { (log UFC/mL) }\end{array}$} \\
\hline & & & \multicolumn{2}{|c|}{ (mg de ácido acético/L) } & & \multicolumn{2}{|c|}{$(\%)$} & \\
\hline \multirow{10}{*}{ 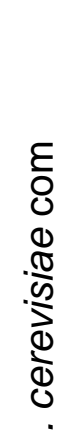 } & \multirow{4}{*}{$\begin{array}{c}\text { Bacillus } \\
\text { stearothermophilus }\end{array}$} & 0 & 763 & 300 & 6,28 & 99,40 & 16,60 & 7,916 \\
\hline & & 24 & 3455 & 375 & 4,80 & 98,00 & 12,40 & 8,157 \\
\hline & & 48 & 740 & 60 & 6,12 & 98,00 & 10,10 & 8,171 \\
\hline & & 72 & 509 & 0 & 7,10 & 97,60 & 8,00 & 8,152 \\
\hline & \multirow{4}{*}{ Bacillus subtilis } & 0 & 2595 & 260 & 4,80 & 96,00 & 22,60 & 7,893 \\
\hline & & 24 & 3520 & 1230 & 5,12 & 68,20 & 9,20 & 7,879 \\
\hline & & 48 & 2590 & 1235 & 5,00 & 49,20 & 6,30 & 7,799 \\
\hline & & 72 & 2810 & 1385 & 4,94 & 39,20 & 3,30 & 7,733 \\
\hline & \multirow{4}{*}{ Bacillus coagulans } & 0 & 720 & 100 & 5,92 & 97,05 & 15,90 & 7,877 \\
\hline & & 24 & 3090 & 266 & 4,89 & 99,20 & 12,00 & 8,202 \\
\hline \multirow{10}{*}{ 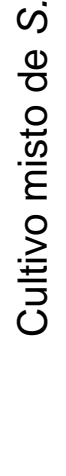 } & & 48 & 679 & 101 & 6,38 & 98,10 & 11,90 & 8,314 \\
\hline & & 72 & 603 & 15 & 6,08 & 98,60 & 10,60 & 8,280 \\
\hline & \multirow{4}{*}{$\begin{array}{c}\text { Lactobacillus } \\
\text { plantarum }\end{array}$} & 0 & 860 & 45 & 6,65 & 99,00 & 17,20 & 8,102 \\
\hline & & 24 & 2907 & 250 & 5,28 & 99,60 & 13,00 & 8,259 \\
\hline & & 48 & 780 & 65 & 6,46 & 99,50 & 9,40 & 8,253 \\
\hline & & 72 & 538 & 0 & 7,17 & 99,20 & 7,40 & 8,239 \\
\hline & \multirow{4}{*}{$\begin{array}{l}\text { Lactobacillus } \\
\text { fermentum }\end{array}$} & 0 & 5315 & 1139 & 3,77 & 98,00 & 16,10 & 8,021 \\
\hline & & 24 & 7665 & 1594 & 3,75 & 77,20 & 12,50 & 7,845 \\
\hline & & 48 & 6000 & 2582 & 3,82 & 48,40 & 7,10 & 7,789 \\
\hline & & 72 & 6020 & 3031 & 3,91 & 25,90 & 5,40 & 7,635 \\
\hline \multirow{4}{*}{\multicolumn{2}{|c|}{ S. cerevisiae (controle) }} & 0 & 1145 & 220 & 5,35 & 97,00 & 15,80 & 8,022 \\
\hline & & 24 & 3644 & 500 & 5,03 & 98,60 & 15,10 & 8,297 \\
\hline & & 48 & 1092 & 399 & 5,63 & 98,80 & 13,40 & 8,358 \\
\hline & & 72 & 1334 & 404 & 5,60 & 99,00 & 11,50 & 8,418 \\
\hline
\end{tabular}


Tabela 33. Resultados das determinações físico-químicas e microbiológicas do $2^{\circ}$ ensaio dos cultivos mistos de $S$. cerevisiae com bactérias ativas

\begin{tabular}{|c|c|c|c|c|c|c|c|c|}
\hline \multirow{3}{*}{\multicolumn{2}{|c|}{ Microrganismos }} & \multirow{3}{*}{ Períodos } & \multicolumn{3}{|c|}{ Determinações físico-químicas } & \multicolumn{3}{|c|}{ Determinações microbiológicas } \\
\hline & & & $\begin{array}{c}\text { Acidez } \\
\text { total }\end{array}$ & $\begin{array}{l}\text { Acidez } \\
\text { volátil }\end{array}$ & \multirow{2}{*}{$\begin{array}{c}\mathrm{pH} \\
-\end{array}$} & $\begin{array}{c}\text { Viabilidade } \\
\text { celular }\end{array}$ & $\begin{array}{c}\text { Taxa de } \\
\text { Brotamento }\end{array}$ & \multirow{2}{*}{$\begin{array}{l}\text { População } \\
\text { de células } \\
(\log U F C / m L)\end{array}$} \\
\hline & & & \multicolumn{2}{|c|}{ (mg de ácido acético/L) } & & \multicolumn{2}{|c|}{$(\%)$} & \\
\hline \multirow{10}{*}{ 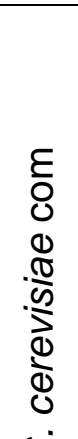 } & \multirow{4}{*}{$\begin{array}{c}\text { Bacillus } \\
\text { stearothermophilus }\end{array}$} & 0 & 857 & 387 & 6,44 & 98,50 & 16,80 & 7,913 \\
\hline & & 24 & 3802 & 610 & 5,00 & 97,70 & 12,40 & 8,157 \\
\hline & & 48 & 833 & 75 & 6,34 & 98,70 & 10,30 & 8,170 \\
\hline & & 72 & 641 & 30 & 7,16 & 97,40 & 8,10 & 8,153 \\
\hline & \multirow{4}{*}{ Bacillus subtilis } & 0 & 3078 & 321 & 4,60 & 96,30 & 21,90 & 7,894 \\
\hline & & 24 & 3787 & 1570 & 5,41 & 68,63 & 9,50 & 7,878 \\
\hline & & 48 & 2101 & 1495 & 5,25 & 49,96 & 6,70 & 7,798 \\
\hline & & 72 & 2969 & 1615 & 5,09 & 39,37 & 3,40 & 7,732 \\
\hline & \multirow{4}{*}{ Bacillus coagulans } & 0 & 843 & 156 & 6,18 & 96,80 & 15,80 & 7,875 \\
\hline & & 24 & 3150 & 225 & 4,72 & 99,27 & 11,90 & 8,203 \\
\hline \multirow{10}{*}{ 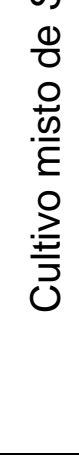 } & & 48 & 695 & 139 & 6,50 & 98,46 & 12,00 & 8,314 \\
\hline & & 72 & 697 & 45 & 6,16 & 99,10 & 10,50 & 8,281 \\
\hline & \multirow{4}{*}{$\begin{array}{c}\text { Lactobacillus } \\
\text { plantarum }\end{array}$} & 0 & 944 & 74 & 6,55 & 98,70 & 17,20 & 8,103 \\
\hline & & 24 & 3143 & 427 & 5,56 & 99,10 & 12,80 & 8,257 \\
\hline & & 48 & 839 & 124 & 6,68 & 98,00 & 9,50 & 8,256 \\
\hline & & 72 & 682 & 26 & 7,35 & 99,10 & 7,40 & 8,240 \\
\hline & \multirow{4}{*}{$\begin{array}{c}\text { Lactobacillus } \\
\text { fermentum }\end{array}$} & 0 & 6150 & 1485 & 3,88 & 98,60 & 16,00 & 8,023 \\
\hline & & 24 & 7914 & 1823 & 3,80 & 77,59 & 12,60 & 7,846 \\
\hline & & 48 & 6069 & 2849 & 3,93 & 49,90 & 7,30 & 7,791 \\
\hline & & 72 & 6500 & 3480 & 4,05 & 25,10 & 5,30 & 7,638 \\
\hline \multirow{4}{*}{\multicolumn{2}{|c|}{ S. cerevisiae (controle) }} & 0 & 1776 & 299 & 5,53 & 97,16 & 15,90 & 8,020 \\
\hline & & 24 & 4063 & 532 & 5,15 & 98,30 & 15,20 & 8,296 \\
\hline & & 48 & 1731 & 443 & 5,80 & 98,70 & 13,20 & 8,356 \\
\hline & & 72 & 1585 & 483 & 5,86 & 99,20 & 11,20 & 8,419 \\
\hline
\end{tabular}


Tabela 34. Resultados das determinações físico-químicas e microbiológicas do $3^{\circ}$ ensaio dos cultivos mistos de $S$. cerevisiae com bactérias ativas

\begin{tabular}{|c|c|c|c|c|c|c|c|c|}
\hline \multirow{3}{*}{\multicolumn{2}{|c|}{ Microrganismos }} & \multirow{3}{*}{ Períodos } & \multicolumn{3}{|c|}{ Determinações físico-químicas } & \multicolumn{3}{|c|}{ Determinações microbiológicas } \\
\hline & & & $\begin{array}{c}\text { Acidez } \\
\text { total }\end{array}$ & $\begin{array}{l}\text { Acidez } \\
\text { volátil }\end{array}$ & \multirow{2}{*}{$\begin{array}{c}\mathrm{pH} \\
- \\
\end{array}$} & $\begin{array}{c}\text { Viabilidade } \\
\text { celular }\end{array}$ & $\begin{array}{c}\text { Taxa de } \\
\text { Brotamento }\end{array}$ & \multirow{2}{*}{$\begin{array}{l}\text { População } \\
\text { de células } \\
\text { (log UFC/mL) }\end{array}$} \\
\hline & & & \multicolumn{2}{|c|}{ (mg de ácido acético/L) } & & \multicolumn{2}{|c|}{$(\%)$} & \\
\hline \multirow{10}{*}{ 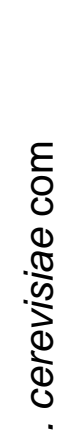 } & \multirow{4}{*}{$\begin{array}{c}\text { Bacillus } \\
\text { stearothermophilus }\end{array}$} & 0 & 750 & 273 & 6,21 & 99,20 & 16,50 & 7,918 \\
\hline & & 24 & 3408 & 440 & 4,75 & 97,90 & 12,20 & 8,156 \\
\hline & & 48 & 737 & 55 & 6,20 & 98,40 & 10,00 & 8,169 \\
\hline & & 72 & 485 & 54 & 7,04 & 97,80 & 8,30 & 8,150 \\
\hline & \multirow{4}{*}{ Bacillus subtilis } & 0 & 2112 & 259 & 4,78 & 95,80 & 23,30 & 7,890 \\
\hline & & 24 & 3253 & 1250 & 5,13 & 68,37 & 9,20 & 7,878 \\
\hline & & 48 & 3079 & 1275 & 4,75 & 48,80 & 6,20 & 7,800 \\
\hline & & 72 & 2651 & 1455 & 4,79 & 39,03 & 3,20 & 7,730 \\
\hline & \multirow{4}{*}{ Bacillus coagulans } & 0 & 597 & 104 & 5,90 & 97,15 & 16,10 & 7,879 \\
\hline & & 24 & 3150 & 225 & 4,72 & 99,27 & 11,90 & 8,203 \\
\hline \multirow{10}{*}{ 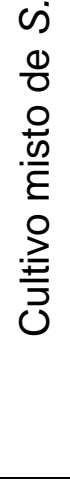 } & & 48 & 595 & 105 & 6,26 & 98,04 & 12,00 & 8,313 \\
\hline & & 72 & 605 & 62 & 6,00 & 98,70 & 10,70 & 8,281 \\
\hline & \multirow{4}{*}{$\begin{array}{c}\text { Lactobacillus } \\
\text { plantarum }\end{array}$} & 0 & 836 & 25 & 6,75 & 99,30 & 17,00 & 8,100 \\
\hline & & 24 & 2875 & 243 & 5,27 & 99,00 & 12,90 & 8,260 \\
\hline & & 48 & 721 & 66 & 6,54 & 98,30 & 9,30 & 8,251 \\
\hline & & 72 & 565 & 19 & 7,23 & 98,60 & 7,30 & 8,237 \\
\hline & \multirow{4}{*}{$\begin{array}{l}\text { Lactobacillus } \\
\text { fermentum }\end{array}$} & 0 & 5680 & 1093 & 3,66 & 97,80 & 15,80 & 8,021 \\
\hline & & 24 & 7716 & 1665 & 3,76 & 77,11 & 12,40 & 7,842 \\
\hline & & 48 & 5970 & 2615 & 3,83 & 48,40 & 7,20 & 7,787 \\
\hline & & 72 & 5840 & 3182 & 3,83 & 27,00 & 5,60 & 7,636 \\
\hline \multirow{4}{*}{\multicolumn{2}{|c|}{ S. cerevisiae (controle) }} & 0 & 1114 & 211 & 5,29 & 97,06 & 16,00 & 8,019 \\
\hline & & 24 & 3825 & 480 & 5,00 & 98,10 & 15,00 & 8,296 \\
\hline & & 48 & 1092 & 376 & 5,64 & 98,90 & 13,30 & 8,352 \\
\hline & & 72 & 1083 & 385 & 5,64 & 99,10 & 11,30 & 8,421 \\
\hline
\end{tabular}


Tabela 35. Resultados das determinações físico-químicas e microbiológicas do $1^{\circ}$ ensaio realizado com os cultivos mistos de S. cerevisiae com bactérias tratadas com calor úmido

\begin{tabular}{|c|c|c|c|c|c|c|c|c|}
\hline \multirow{3}{*}{\multicolumn{2}{|c|}{ Microrganismos }} & \multirow{3}{*}{ Períodos } & \multicolumn{3}{|c|}{ Determinações físico-químicas } & \multicolumn{3}{|c|}{ Determinações microbiológicas } \\
\hline & & & $\begin{array}{l}\text { Acidez } \\
\text { total }\end{array}$ & $\begin{array}{l}\text { Acidez } \\
\text { volátil }\end{array}$ & \multirow{2}{*}{$\begin{array}{c}\mathrm{pH} \\
-\end{array}$} & $\begin{array}{c}\text { Viabilidade } \\
\text { celular }\end{array}$ & $\begin{array}{c}\text { Taxa de } \\
\text { Brotamento }\end{array}$ & \multirow{2}{*}{$\begin{array}{c}\text { População } \\
\text { de células } \\
(\log \text { UFC/mL) }\end{array}$} \\
\hline & & & \multicolumn{2}{|c|}{ (mg de ácido acético/L) } & & \multicolumn{2}{|c|}{$(\%)$} & \\
\hline \multirow{9}{*}{ 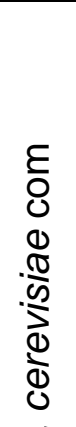 } & \multirow{4}{*}{$\begin{array}{c}\text { Bacillus } \\
\text { stearothermophilus }\end{array}$} & 0 & 1209 & 184 & 5,42 & 96,00 & 30,20 & 7,921 \\
\hline & & 24 & 3627 & 283 & 4,96 & 97,80 & 9,70 & 8,285 \\
\hline & & 48 & 934 & 156 & 5,90 & 97,60 & 6,50 & 8,415 \\
\hline & & 72 & 906 & 152 & 5,92 & 98,00 & 6,00 & 8,367 \\
\hline & \multirow{4}{*}{ Bacillus subtilis } & 0 & 1300 & 180 & 5,57 & 97,60 & 40,00 & 7,782 \\
\hline & & 24 & 3300 & 300 & 5,22 & 98,30 & 12,50 & 8,233 \\
\hline & & 48 & 997 & 126 & 5,87 & 97,90 & 9,50 & 8,274 \\
\hline & & 72 & 1004 & 101 & 5,87 & 98,30 & 9,00 & 8,264 \\
\hline & \multirow{4}{*}{ Bacillus coagulans } & 0 & 1100 & 168 & 5,42 & 96,20 & 22,70 & 7,981 \\
\hline \multirow{11}{*}{ 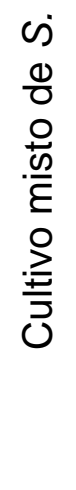 } & & 24 & 4435 & 266 & 5,06 & 98,20 & 10,30 & 8,272 \\
\hline & & 48 & 874 & 143 & 6,03 & 97,00 & 6,00 & 8,420 \\
\hline & & 72 & 883 & 158 & 5,99 & 98,00 & 6,60 & 8348 \\
\hline & \multirow{4}{*}{$\begin{array}{c}\text { Lactobacillus } \\
\text { plantarum }\end{array}$} & 0 & 1328 & 218 & 5046 & 93,00 & 30,90 & 7,815 \\
\hline & & 24 & 3394 & 309 & 4,93 & 97,30 & 10,70 & 8,196 \\
\hline & & 48 & 983 & 202 & 5,96 & 97,00 & 7,90 & 8,330 \\
\hline & & 72 & 925 & 163 & 5,99 & 97,70 & 7,30 & 8,316 \\
\hline & \multirow{4}{*}{$\begin{array}{l}\text { Lactobacillus } \\
\text { fermentum }\end{array}$} & 0 & 4416 & 877 & 3,99 & 91,60 & 25,40 & 7,783 \\
\hline & & 24 & 6200 & 1330 & 4,22 & 94,90 & 21,60 & 8,025 \\
\hline & & 48 & 4208 & 1511 & 4014 & 95,20 & 17,20 & 7,992 \\
\hline & & 72 & 3523 & 1073 & 4,34 & 95,80 & 18,40 & 8,005 \\
\hline \multirow{4}{*}{\multicolumn{2}{|c|}{ S. cerevisiae (controle) }} & 0 & 1151 & 147 & 5,54 & 95,00 & 22,60 & 7,825 \\
\hline & & 24 & 4300 & 234 & 5,20 & 97,60 & 17,60 & 8,302 \\
\hline & & 48 & 959 & 173 & 5,72 & 97,50 & 12,80 & 8,384 \\
\hline & & 72 & 955 & 173 & 5,74 & 97,60 & 10,90 & 8,376 \\
\hline
\end{tabular}


Tabela 36. Resultados das determinações físico-químicas e microbiológicas do $2^{\circ}$ ensaio realizado com os cultivos mistos de S. cerevisiae com bactérias tratadas com calor úmido

\begin{tabular}{|c|c|c|c|c|c|c|c|c|}
\hline \multirow{3}{*}{\multicolumn{2}{|c|}{ Microrganismos }} & \multirow{3}{*}{ Períodos } & \multicolumn{3}{|c|}{ Determinações físico-químicas } & \multicolumn{3}{|c|}{ Determinações microbiológicas } \\
\hline & & & $\begin{array}{l}\text { Acidez } \\
\text { total }\end{array}$ & $\begin{array}{l}\text { Acidez } \\
\text { volátil }\end{array}$ & \multirow{2}{*}{$\begin{array}{c}\mathrm{pH} \\
-\end{array}$} & $\begin{array}{c}\text { Viabilidade } \\
\text { celular }\end{array}$ & $\begin{array}{c}\text { Taxa de } \\
\text { Brotamento }\end{array}$ & \multirow{2}{*}{$\begin{array}{c}\text { População } \\
\text { de células } \\
(\log \text { UFC/mL) }\end{array}$} \\
\hline & & & \multicolumn{2}{|c|}{ (mg de ácido acético/L) } & & \multicolumn{2}{|c|}{$(\%)$} & \\
\hline \multirow{9}{*}{ 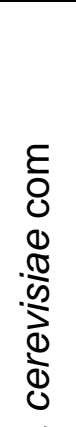 } & \multirow{4}{*}{$\begin{array}{c}\text { Bacillus } \\
\text { stearothermophilus }\end{array}$} & 0 & 1269 & 165 & 5,32 & 96,40 & 31,60 & 7,923 \\
\hline & & 24 & 3557 & 269 & 5,12 & 97,50 & 9,50 & 8,283 \\
\hline & & 48 & 964 & 148 & 5,89 & 97,80 & 6,30 & 8,412 \\
\hline & & 72 & 902 & 152 & 5,89 & 98,20 & 6,10 & 8,365 \\
\hline & \multirow{4}{*}{ Bacillus subtilis } & 0 & 1476 & 168 & 5,37 & 97,75 & 33,00 & 7,780 \\
\hline & & 24 & 3402 & 312 & 5,02 & 98,20 & 10,60 & 8,232 \\
\hline & & 48 & 993 & 138 & 5,86 & 98,00 & 9,30 & 8,273 \\
\hline & & 72 & 1001 & 114 & 5,82 & 98,10 & 9,30 & 8,262 \\
\hline & \multirow{4}{*}{ Bacillus coagulans } & 0 & 1150 & 184 & 5049 & 96,50 & 22,30 & 7,982 \\
\hline \multirow{11}{*}{ 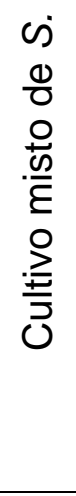 } & & 24 & 4535 & 286 & 5,08 & 98,30 & 11,20 & 8,270 \\
\hline & & 48 & 894 & 179 & 6,07 & 97,10 & 6,00 & 8,418 \\
\hline & & 72 & 899 & 146 & 6,01 & 98,60 & 6,30 & 8,345 \\
\hline & \multirow{4}{*}{$\begin{array}{c}\text { Lactobacillus } \\
\text { plantarum }\end{array}$} & 0 & 1346 & 219 & 5,49 & 94,00 & 29,90 & 7,813 \\
\hline & & 24 & 3334 & 324 & 4,99 & 97,60 & 10,50 & 8,196 \\
\hline & & 48 & 989 & 205 & 5,89 & 97,80 & 7,70 & 8,328 \\
\hline & & 72 & 916 & 183 & 6,02 & 98,20 & 7,0 & 8,314 \\
\hline & \multirow{4}{*}{$\begin{array}{l}\text { Lactobacillus } \\
\text { fermentum }\end{array}$} & 0 & 4486 & 887 & 4,01 & 95,90 & 26,30 & 7,781 \\
\hline & & 24 & 6300 & 1358 & 4,36 & 95,00 & 22,40 & 8,021 \\
\hline & & 48 & 4246 & 1495 & 4,20 & 95,10 & 16,90 & 7,994 \\
\hline & & 72 & 3453 & 1095 & 4,41 & 95,60 & 18,30 & 8,001 \\
\hline \multirow{4}{*}{\multicolumn{2}{|c|}{ S. cerevisiae (controle) }} & 0 & 1203 & 150 & 5,60 & 95,60 & 24,10 & 7,826 \\
\hline & & 24 & 4330 & 268 & 5,16 & 97,80 & 18,00 & 8,300 \\
\hline & & 48 & 964 & 168 & 5,79 & 97,60 & 14,00 & 8,385 \\
\hline & & 72 & 948 & 170 & 5,69 & 97,30 & 12,00 & 8,377 \\
\hline
\end{tabular}


Tabela 37. Resultados das determinações físico-químicas e microbiológicas do $1^{\circ}$ ensaio realizado com os cultivos mistos de S. cerevisiae com bactérias tratadas com antimicrobiano Kamoran $\mathrm{HJ}$

\begin{tabular}{|c|c|c|c|c|c|c|c|c|}
\hline \multirow{3}{*}{\multicolumn{2}{|c|}{ Microrganismos }} & \multirow{3}{*}{ Períodos } & \multicolumn{3}{|c|}{ Determinações físico-químicas } & \multicolumn{3}{|c|}{ Determinações microbiológicas } \\
\hline & & & $\begin{array}{l}\text { Acidez } \\
\text { total }\end{array}$ & $\begin{array}{l}\text { Acidez } \\
\text { volátil }\end{array}$ & \multirow{2}{*}{$\begin{array}{c}\mathrm{pH} \\
- \\
\end{array}$} & $\begin{array}{c}\text { Viabilidade } \\
\text { celular }\end{array}$ & $\begin{array}{c}\text { Taxa de } \\
\text { Brotamento }\end{array}$ & \multirow{2}{*}{$\begin{array}{l}\text { População } \\
\text { de células } \\
\text { (log UFC/mL) }\end{array}$} \\
\hline & & & \multicolumn{2}{|c|}{ (mg de ácido acético/L) } & & \multicolumn{2}{|c|}{$(\%)$} & \\
\hline \multirow{10}{*}{ 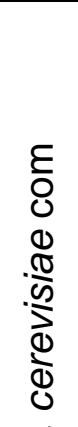 } & \multirow{4}{*}{$\begin{array}{c}\text { Bacillus } \\
\text { stearothermophilus }\end{array}$} & 0 & 1473 & 170 & 5,98 & 97,00 & 15,60 & 8,103 \\
\hline & & 24 & 1349 & 218 & 5,22 & 98,90 & 19,20 & 8,204 \\
\hline & & 48 & 1276 & 0 & 6,16 & 98,80 & 14,50 & 8,212 \\
\hline & & 72 & 1210 & 0 & 6,89 & 97,70 & 15,80 & 8,274 \\
\hline & \multirow{4}{*}{ Bacillus subtilis } & 0 & 1563 & 134 & 5,58 & 96,55 & 15,60 & 8,045 \\
\hline & & 24 & 2600 & 248 & 5,30 & 98,80 & 23,20 & 8,132 \\
\hline & & 48 & 1555 & 0 & 6,13 & 99,50 & 13,80 & 8,274 \\
\hline & & 72 & 1196 & 0 & 6,86 & 98,50 & 10,20 & 8,255 \\
\hline & \multirow{4}{*}{ Bacillus coagulans } & 0 & 1406 & 105 & 5,93 & 97,90 & 13,00 & 8,030 \\
\hline & & 24 & 2691 & 292 & 5,15 & 99,40 & 20,60 & 8,193 \\
\hline \multirow{10}{*}{ 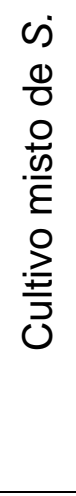 } & & 48 & 1206 & 0 & 6,09 & 99,30 & 12,10 & 8,262 \\
\hline & & 72 & 1145 & 0 & 6,73 & 98,70 & 10,10 & 8,303 \\
\hline & \multirow{4}{*}{$\begin{array}{c}\text { Lactobacillus } \\
\text { plantarum }\end{array}$} & 0 & 1336 & 202 & 5,32 & 96,00 & 30,00 & 7,928 \\
\hline & & 24 & 3646 & 291 & 5,04 & 96,30 & 15,20 & 8,232 \\
\hline & & 48 & 1067 & 58 & 6,17 & 97,60 & 7,30 & 8,271 \\
\hline & & 72 & 1016 & 0 & 6,30 & 97,40 & 8,30 & 8,228 \\
\hline & \multirow{4}{*}{$\begin{array}{l}\text { Lactobacillus } \\
\text { fermentum }\end{array}$} & 0 & 4161 & 713 & 4,18 & 92,60 & 36,10 & 7,756 \\
\hline & & 24 & 5910 & 12,22 & 3,96 & 94,80 & 26,60 & 7,983 \\
\hline & & 48 & 3860 & 1470 & 4,04 & 95,40 & 24,90 & 8,042 \\
\hline & & 72 & 3208 & 1142 & 4,29 & 95,50 & 22,10 & 8,029 \\
\hline \multirow{4}{*}{\multicolumn{2}{|c|}{ S. cerevisiae (controle) }} & 0 & 1265 & 144 & 5,50 & 96,50 & 21,60 & 7,975 \\
\hline & & 24 & 3942 & 184 & 5,22 & 98,20 & 20,70 & 8,212 \\
\hline & & 48 & 1032 & 52 & 5,00 & 98,30 & 16,20 & 8,274 \\
\hline & & 72 & 1091 & 66 & 6,01 & 98,20 & 14,40 & 8,343 \\
\hline
\end{tabular}


Tabela 38. Resultados das determinações físico-químicas e microbiológicas do $2^{\circ}$ ensaio realizado com os cultivos mistos de S. cerevisiae com bactérias tratadas com antimicrobiano Kamoran $\mathrm{HJ}$

\begin{tabular}{|c|c|c|c|c|c|c|c|c|}
\hline \multirow{3}{*}{\multicolumn{2}{|c|}{ Microrganismos }} & \multirow{3}{*}{ Períodos } & \multicolumn{3}{|c|}{ Determinações físico-químicas } & \multicolumn{3}{|c|}{ Determinações microbiológicas } \\
\hline & & & $\begin{array}{c}\text { Acidez } \\
\text { total }\end{array}$ & $\begin{array}{l}\text { Acidez } \\
\text { volátil }\end{array}$ & \multirow{2}{*}{$\begin{array}{c}\mathrm{pH} \\
- \\
\end{array}$} & $\begin{array}{c}\text { Viabilidade } \\
\text { celular }\end{array}$ & $\begin{array}{c}\text { Taxa de } \\
\text { Brotamento }\end{array}$ & \multirow{2}{*}{$\begin{array}{l}\text { População } \\
\text { de células } \\
\text { (log UFC/mL) }\end{array}$} \\
\hline & & & \multicolumn{2}{|c|}{ (mg de ácido acético/L) } & & \multicolumn{2}{|c|}{$(\%)$} & \\
\hline \multirow{10}{*}{ 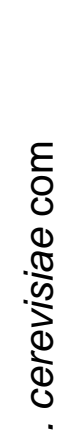 } & \multirow{4}{*}{$\begin{array}{c}\text { Bacillus } \\
\text { stearothermophilus }\end{array}$} & 0 & 1499 & 162 & 5,89 & 96,80 & 15,90 & 8,101 \\
\hline & & 24 & 1389 & 225 & 5,26 & 98,80 & 21,00 & 8,203 \\
\hline & & 48 & 1273 & 31 & 6,14 & 98,70 & 15,10 & 8,210 \\
\hline & & 72 & 1212 & 26 & 6,75 & 97,30 & 15,90 & 8,274 \\
\hline & \multirow{4}{*}{ Bacillus subtilis } & 0 & 1625 & 156 & 5,62 & 96,85 & 15,60 & 8,044 \\
\hline & & 24 & 2660 & 249 & 5,16 & 98,60 & 21,20 & 8,126 \\
\hline & & 48 & 1253 & 39 & 6,09 & 99,30 & 14,30 & 8,275 \\
\hline & & 72 & 1180 & 29 & 6,84 & 98,40 & 11,00 & 8,253 \\
\hline & \multirow{4}{*}{ Bacillus coagulans } & 0 & 1403 & 115 & 5,89 & 97,80 & 12,50 & 8,029 \\
\hline & & 24 & 2685 & 272 & 5,16 & 99,20 & 19,80 & 8,195 \\
\hline \multirow{10}{*}{ 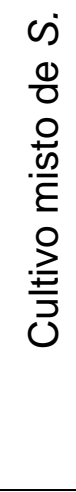 } & & 48 & 1186 & 38 & 6,20 & 99,00 & 11,60 & 8,260 \\
\hline & & 72 & 1144 & 25 & 6,89 & 98,90 & 9,90 & 8,301 \\
\hline & \multirow{4}{*}{$\begin{array}{c}\text { Lactobacillus } \\
\text { plantarum }\end{array}$} & 0 & 1352 & 199 & 5,36 & 96,00 & 24,30 & 7,930 \\
\hline & & 24 & 366 & 286 & 5,12 & 96,20 & 14,90 & 8,230 \\
\hline & & 48 & 1098 & 53 & 6,15 & 97,50 & 10,20 & 8,269 \\
\hline & & 72 & 1046 & 32 & 6,29 & 97,30 & 9,50 & 8,226 \\
\hline & \multirow{4}{*}{$\begin{array}{l}\text { Lactobacillus } \\
\text { fermentum }\end{array}$} & 0 & 4123 & 746 & 4,16 & 96,00 & 31,00 & 7,758 \\
\hline & & 24 & 5896 & 1234 & 3,99 & 96,00 & 24,00 & 7,982 \\
\hline & & 48 & 3799 & 1478 & 4,03 & 95,80 & 23,70 & 8,041 \\
\hline & & 72 & 3199 & 1146 & 4,31 & 95,30 & 21,40 & 8,028 \\
\hline \multirow{4}{*}{\multicolumn{2}{|c|}{ S. cerevisiae (controle) }} & 0 & 1264 & 152 & 5,65 & 96,80 & 22,90 & 7,976 \\
\hline & & 24 & 3896 & 183 & 5,26 & 98,10 & 23,40 & 8,210 \\
\hline & & 48 & 1043 & 55 & 5,12 & 98,50 & 15,90 & 8,272 \\
\hline & & 72 & 1065 & 61 & 5,96 & 98,50 & 13,80 & 8,341 \\
\hline
\end{tabular}


Tabela 39. Resultados das determinações físico-químicas e microbiológicas do $1^{\circ}$ ensaio realizado com os cultivos mistos de S. cerevisiae com bactérias tratadas com radiação gama

\begin{tabular}{|c|c|c|c|c|c|c|c|c|}
\hline \multirow{3}{*}{\multicolumn{2}{|c|}{ Microrganismos }} & \multirow{3}{*}{ Períodos } & \multicolumn{3}{|c|}{ Determinações físico-químicas } & \multicolumn{3}{|c|}{ Determinações microbiológicas } \\
\hline & & & $\begin{array}{c}\text { Acidez } \\
\text { total }\end{array}$ & $\begin{array}{l}\text { Acidez } \\
\text { volátil }\end{array}$ & \multirow{2}{*}{$\begin{array}{c}\mathrm{pH} \\
- \\
\end{array}$} & $\begin{array}{c}\text { Viabilidade } \\
\text { celular }\end{array}$ & $\begin{array}{c}\text { Taxa de } \\
\text { Brotamento }\end{array}$ & \multirow{2}{*}{$\begin{array}{l}\text { População } \\
\text { de células } \\
\text { (log UFC/mL) }\end{array}$} \\
\hline & & & \multicolumn{2}{|c|}{ (mg de ácido acético/L) } & & \multicolumn{2}{|c|}{$(\%)$} & \\
\hline \multirow{10}{*}{ 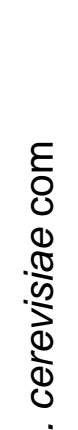 } & \multirow{4}{*}{$\begin{array}{c}\text { Bacillus } \\
\text { stearothermophilus }\end{array}$} & 0 & 1629 & 265 & 4,72 & 96,60 & 28,80 & 8,103 \\
\hline & & 24 & 4575 & 432 & 4,61 & 94,20 & 25,20 & 8,204 \\
\hline & & 48 & 1048 & 137 & 5,17 & 96,40 & 23,40 & 8,212 \\
\hline & & 72 & 956 & 92 & 5,30 & 95,60 & 15,30 & 8,274 \\
\hline & \multirow{4}{*}{ Bacillus subtilis } & 0 & 2180 & 151 & 5,28 & 97,20 & 25,50 & 8,045 \\
\hline & & 24 & 2853 & 191 & 5,19 & 90,30 & 21,00 & 8,032 \\
\hline & & 48 & 1104 & 164 & 5,60 & 88,30 & 19,50 & 7,974 \\
\hline & & 72 & 1362 & 94 & 5,48 & 88,50 & 13,10 & 7,855 \\
\hline & \multirow{4}{*}{ Bacillus coagulans } & 0 & 1568 & 298 & 4,68 & 96,70 & 27,30 & 8,030 \\
\hline & & 24 & 4230 & 435 & 4,64 & 97,90 & 26,50 & 8,123 \\
\hline \multirow{10}{*}{ 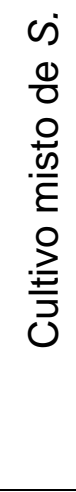 } & & 48 & 1247 & 263 & 4,99 & 98,00 & 24,10 & 8,209 \\
\hline & & 72 & 1079 & 170 & 5,16 & 98,60 & 13,30 & 8,233 \\
\hline & \multirow{4}{*}{$\begin{array}{c}\text { Lactobacillus } \\
\text { plantarum }\end{array}$} & 0 & 1591 & 270 & 4,85 & 96,60 & 20,10 & 7,928 \\
\hline & & 24 & 4950 & 402 & 4,78 & 97,20 & 26,40 & 8,232 \\
\hline & & 48 & 1163 & 202 & 5,29 & 97,10 & 25,10 & 8,271 \\
\hline & & 72 & 1255 & 167 & 5,28 & 97,60 & 16,10 & 8,328 \\
\hline & \multirow{4}{*}{$\begin{array}{l}\text { Lactobacillus } \\
\text { fermentum }\end{array}$} & 0 & 4544 & 934 & 3,75 & 97,20 & 25,90 & 7,956 \\
\hline & & 24 & 7290 & 1110 & 3,82 & 96,40 & 28,20 & 7,983 \\
\hline & & 48 & 4070 & 1153 & 3,93 & 93,40 & 28,30 & 7,942 \\
\hline & & 72 & 4200 & 1711 & 4,00 & 93,00 & 26,20 & 7,929 \\
\hline \multirow{4}{*}{\multicolumn{2}{|c|}{ S. cerevisiae (controle) }} & 0 & 972 & 155 & 4,78 & 97,00 & 27,90 & 8,075 \\
\hline & & 24 & 3590 & 275 & 4,65 & 98,30 & 31,30 & 8,225 \\
\hline & & 48 & 825 & 218 & 4,94 & 98,10 & 28,00 & 8,297 \\
\hline & & 72 & 741 & 157 & 5,02 & 98,10 & 16,80 & 8,359 \\
\hline
\end{tabular}


Tabela 40. Resultados das determinações físico-químicas e microbiológicas do $2^{\circ}$ ensaio realizado com os cultivos mistos de S. cerevisiae com bactérias tratadas com radiação gama

\begin{tabular}{|c|c|c|c|c|c|c|c|c|}
\hline \multirow{3}{*}{\multicolumn{2}{|c|}{ Microrganismos }} & \multirow{3}{*}{ Períodos } & \multicolumn{3}{|c|}{ Determinações físico-químicas } & \multicolumn{3}{|c|}{ Determinações microbiológicas } \\
\hline & & & $\begin{array}{c}\text { Acidez } \\
\text { total }\end{array}$ & $\begin{array}{l}\text { Acidez } \\
\text { volátil }\end{array}$ & \multirow{2}{*}{$\begin{array}{c}\mathrm{pH} \\
- \\
\end{array}$} & $\begin{array}{c}\text { Viabilidade } \\
\text { celular }\end{array}$ & $\begin{array}{c}\text { Taxa de } \\
\text { Brotamento }\end{array}$ & \multirow{2}{*}{$\begin{array}{l}\text { População } \\
\text { de células } \\
\text { (log UFC/mL) }\end{array}$} \\
\hline & & & \multicolumn{2}{|c|}{ (mg de ácido acético/L) } & & \multicolumn{2}{|c|}{$(\%)$} & \\
\hline \multirow{10}{*}{ 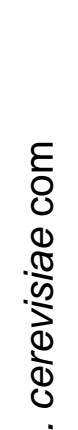 } & \multirow{4}{*}{$\begin{array}{c}\text { Bacillus } \\
\text { stearothermophilus }\end{array}$} & 0 & 1560 & 269 & 4,72 & 96,50 & 28,80 & 8,102 \\
\hline & & 24 & 4369 & 446 & 4,65 & 94,00 & 25,80 & 8,201 \\
\hline & & 48 & 1055 & 145 & 5,16 & 96,30 & 23,80 & 8,212 \\
\hline & & 72 & 1001 & 96 & 5,32 & 95,40 & 15,50 & 8,275 \\
\hline & \multirow{4}{*}{ Bacillus subtilis } & 0 & 2142 & 163 & 5,26 & 97,30 & 25,90 & 8,044 \\
\hline & & 24 & 2849 & 185 & 5,18 & 90,40 & 21,00 & 8,031 \\
\hline & & 48 & 1115 & 176 & 5,68 & 88,50 & 19,10 & 7,975 \\
\hline & & 72 & 1265 & 95 & 5,54 & 88,50 & 13,30 & 7,857 \\
\hline & \multirow{4}{*}{ Bacillus coagulans } & 0 & 1564 & 299 & 4,72 & 96,80 & 27,10 & 8,029 \\
\hline & & 24 & 4169 & 443 & 4,65 & 98,00 & 26,70 & 8,124 \\
\hline \multirow{10}{*}{ 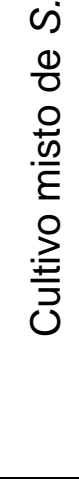 } & & 48 & 1267 & 271 & 5,01 & 98,10 & 23,90 & 8,207 \\
\hline & & 72 & 1103 & 176 & 5,15 & 98,60 & 13,50 & 8,231 \\
\hline & \multirow{4}{*}{$\begin{array}{c}\text { Lactobacillus } \\
\text { plantarum }\end{array}$} & 0 & 1610 & 278 & 4,86 & 96,70 & 20,30 & 7,927 \\
\hline & & 24 & 4876 & 414 & 4,76 & 97,40 & 26,40 & 8,233 \\
\hline & & 48 & 1146 & 206 & 5,27 & 97,10 & 25,30 & 8,269 \\
\hline & & 72 & 1256 & 179 & 5,28 & 97,70 & 16,00 & 8,330 \\
\hline & \multirow{4}{*}{$\begin{array}{l}\text { Lactobacillus } \\
\text { fermentum }\end{array}$} & 0 & 4544 & 948 & 3,78 & 97,40 & 25,00 & 7,954 \\
\hline & & 24 & 6989 & 1116 & 3,81 & 96,50 & 28,20 & 7,982 \\
\hline & & 48 & 4010 & 1169 & 3,95 & 93,50 & 28,50 & 7,941 \\
\hline & & 72 & 4187 & 1738 & 4,01 & 92,80 & 26,60 & 7,930 \\
\hline \multirow{4}{*}{\multicolumn{2}{|c|}{ S. cerevisiae (controle) }} & 0 & 968 & 156 & 4,76 & 97,20 & 27,80 & 8,073 \\
\hline & & 24 & 3590 & 275 & 4,65 & 98,30 & 31,30 & 8,225 \\
\hline & & 48 & 824 & 226 & 4,95 & 98,20 & 28,10 & 8,295 \\
\hline & & 72 & 759 & 165 & 5,01 & 98,30 & 16,70 & 8,361 \\
\hline
\end{tabular}


Tabela 41. Média geral, $\mathrm{R}^{2}$, coeficiente de variação e desvio padrão para as variáveis quando em cultivo misto de bactérias ativas e $S$. cerevisiae

\begin{tabular}{c|c|c|c|c}
\hline Variável & Média Geral & $\mathbf{R}^{2}$ & $\begin{array}{c}\text { Coeficiente } \\
\text { de variação }\end{array}$ & $\begin{array}{c}\text { Desvio } \\
\text { Padrão }\end{array}$ \\
\hline Acidez Total & $2540,542 \mathrm{mg}$ de ác. acético/L & 0,9910 & 9,43 & 239,696 \\
\hline Acidez volátil & $698,5417 \mathrm{mg}$ de ác. acético/L & 0,9905 & 14,55 & 101,658 \\
\hline $\mathrm{pH}$ & 5,446528 & 0,9894 & 2,31 & 0,126 \\
\hline Viabilidade celular & $86,60667 \%$ & 0,9997 & 0,47 & 0,407 \\
\hline Taxa de brotamento & $11,78611 \%$ & 0,9986 & 1,63 & 0,192 \\
\hline População de células & 8,066847 log UFC/mL & 0,9999 & 0,02 & 0,002 \\
\hline
\end{tabular}

Tabela 42. Média geral, $\mathrm{R}^{2}$, coeficiente de variação e desvio padrão para as variáveis em cultivo misto de bactérias tratadas com calor e $S$. cerevisiae

\begin{tabular}{c|c|c|c|c}
\hline Variável & Média Geral & $\mathbf{R}^{2}$ & $\begin{array}{c}\text { Coeficiente } \\
\text { de variação }\end{array}$ & $\begin{array}{c}\text { Desvio } \\
\text { Padrão }\end{array}$ \\
\hline Acidez Total & $2218,083 \mathrm{mg}$ de ác. acético/L & 0,9996 & 1,98 & 44,002 \\
\hline Acidez volátil & $362,7083 \mathrm{mg}$ de ác. acético/L & 0,9995 & 3,27 & 11,881 \\
\hline $\mathrm{pH}$ & 5,354375 & 0,9950 & 1,13 & 0,060 \\
\hline Viabilidade celular & $96,89688 \%$ & 0,8972 & 0,69 & 0,675 \\
\hline Taxa de brotamento & $15,43750 \%$ & 0,9914 & 7,45 & 1,150 \\
\hline População de células & $8,162333 \mathrm{log}$ UFC/mL & 0,9999 & 0,02 & 0,001 \\
\hline
\end{tabular}

Tabela 43. Média geral, $\mathrm{R}^{2}$, coeficiente de variação e desvio padrão para as variáveis quando em cultivo misto de bactérias tratadas com Kamoran $\mathrm{HJ}$ e S. cerevisiae

\begin{tabular}{c|c|c|c|c}
\hline Variável & Média Geral & $\mathbf{R}^{2}$ & $\begin{array}{c}\text { Coeficiente } \\
\text { de variação }\end{array}$ & $\begin{array}{c}\text { Desvio } \\
\text { Padrão }\end{array}$ \\
\hline Acidez Total & $2080,625 \mathrm{mg}$ de ác. acético/L & 0,9998 & 1,04 & 21,704 \\
\hline Acidez volátil & $285,4792 \mathrm{mg}$ de ác. acético/L & 0,9993 & 4,97 & 14,187 \\
\hline $\mathrm{pH}$ & 5,548750 & 0,9978 & 0,98 & 0,055 \\
\hline Viabilidade celular & $97,48958 \%$ & 0,9309 & 0,55 & 0,541 \\
\hline Taxa de brotamento & $17,62292 \%$ & 0,9742 & 8,04 & 1,416 \\
\hline População de células & 8,147792 log UFC/mL & 0,9999 & 0,02 & 0,001 \\
\hline
\end{tabular}

Tabela 44. Média geral, $\mathrm{R}^{2}$, coeficiente de variação e desvio padrão para as variáveis quando em cultivo misto de bactérias tratadas com irradiação e S. cerevisiae

\begin{tabular}{c|c|c|c|c}
\hline Variável & Média Geral & $\mathbf{R}^{2}$ & $\begin{array}{c}\text { Coeficiente } \\
\text { de variação }\end{array}$ & $\begin{array}{c}\text { Desvio } \\
\text { Padrão }\end{array}$ \\
\hline Acidez Total & $2442,625 \mathrm{mg}$ de ác. acético/L & 0,9994 & 2,40 & 58,780 \\
\hline Acidez volátil & $397,7083 \mathrm{mg}$ de ác. acético/L & 09998 & 1,85 & 7,354 \\
\hline $\mathrm{pH}$ & 4,833750 & 0,9992 & 0,41 & 0,019 \\
\hline Viabilidade celular & $95,78958 \%$ & 0,9994 & 0,11 & 0,097 \\
\hline Taxa de brotamento & $23,49583 \%$ & 0,9991 & 0,92 & 0,215 \\
\hline População de células & 8,117250 log UFC/mL & 0,9999 & 0,01 & 0,002 \\
\hline
\end{tabular}


Tabela 45. Quadrado médio (Q.M.) da análise de variância, seguido da significância do Teste $F$ dos fatores Microrganismo (Micro), Período (Per) e Interação (Micro * Per) para todas as variáveis em cultivo misto de bactérias ativas e $S$. cerevisiae

\begin{tabular}{|c|c|c|c|c|c|c|c|}
\hline \multirow{2}{*}{$\begin{array}{l}\text { Fonte de } \\
\text { variação }\end{array}$} & \multirow[b]{2}{*}{ G.L. } & Ac. total & Ac. volátil & $\mathrm{pH}$ & Viabilidade & Brotamento & População \\
\hline & & \multicolumn{6}{|c|}{ Q.M. } \\
\hline Variável & 23 & $13207619,5^{\star \star}$ & $2271378,57^{\star \star}$ & $3,13^{\star \star}$ & $1516,50^{\star \star}$ & $58,37^{\star \star}$ & $0,15^{\star \star}$ \\
\hline Micro & 5 & $47393312,8^{\star \star}$ & 8249030,19 ** & $10,70^{\star \star}$ & $4044,06^{\star \star}$ & $22,60^{\star \star}$ & $0,46^{\star \star}$ \\
\hline Per & 3 & $7,4^{\star \star}$ & $75^{\star \star}$ & $3,14^{\star \star}$ & $1537,14^{\star \star}$ & 314,16 ** & $0,08^{\star \star}$ \\
\hline Micro * Per & 15 & $416110,8^{\star \star}$ & $558135,00^{\star \star}$ & $0,61^{\star \star}$ & $669,85^{\star \star}$ & $19,14^{\star \star}$ & $0,06^{\star \star}$ \\
\hline Resíduos & 48 & 57454,2 & 10334,39 & 0,02 & 0,16 & 0,04 & 0,0000027 \\
\hline Total & 71 & & & & & & \\
\hline
\end{tabular}

Tabela 46. Quadrado médio (Q.M.) da análise de variância, seguido da significância do Teste $F$ dos fatores Microrganismo (Micro), Período (Per) e Interação (Micro * Per) para todas as variáveis em cultivo misto de bactérias tratadas com calor e S. cerevisiae

\begin{tabular}{|c|c|c|c|c|c|c|c|}
\hline \multirow{2}{*}{$\begin{array}{l}\text { Fonte de } \\
\text { variação }\end{array}$} & \multirow[b]{2}{*}{ G.L. } & Ac. total & Ac. volátil & $\mathrm{pH}$ & Viabilidade & Brotamento & População \\
\hline & & \multicolumn{6}{|c|}{ Q.M. } \\
\hline Variável & 23 & 5378300,9 ** & $320490,78^{\star \star}$ & $0,77^{\star \star}$ & $4,16^{\star *}$ & $160,32^{\star \star}$ & 0,09 ** \\
\hline Micro & 5 & $10992685,78^{* *}$ & $1358829,48^{* *}$ & $2,53^{\star \star}$ & $9,64^{* *}$ & $87,19^{* *}$ & $0,11^{* *}$ \\
\hline Per & 3 & 21884073,50 ** & $72051,14^{\star \star}$ & $1,33^{\star \star}$ & $11,44^{\star *}$ & $914,64^{\star \star}$ & $0,53^{\star \star}$ \\
\hline Micro * Per & 15 & $205684,82^{\star \star}$ & $24065,80^{\star \star}$ & $0,07^{\star \star}$ & $0,87 n s$ & $33,83^{\star \star}$ & $0,008^{\star \star}$ \\
\hline Resíduos & 24 & 1936,3 & 141,17 & 0,0037 & 0,46 & 1,32 & 0,0000023 \\
\hline Total & 47 & & & & & & \\
\hline
\end{tabular}

Tabela 47. Quadrado médio (Q.M.) da análise de variância, seguido da significância do Teste F dos fatores Microrganismo (Micro), Período (Per) e Interação (Micro * Per) para todas as variáveis em cultivo misto de bactérias tratadas com Kamoran $\mathrm{HJ}$ e $\mathrm{S}$. cerevisiae

\begin{tabular}{|c|c|c|c|c|c|c|c|}
\hline \multirow{2}{*}{$\begin{array}{l}\text { Fonte de } \\
\text { variação }\end{array}$} & \multirow[b]{2}{*}{ G.L. } & Ac. total & Ac. volátil & $\mathrm{pH}$ & Viabilidade & Brotamento & População \\
\hline & & \multicolumn{6}{|c|}{ Q.M. } \\
\hline Variável & 23 & $3583991,88^{\star \star}$ & $348467,98^{\star \star}$ & $1,44^{\star \star}$ & $4,12^{\star *}$ & $79,31^{\star \star}$ & $0,05^{\text {** }}$ \\
\hline Micro & 5 & $9435800,00^{\star \star}$ & $1416183,52^{\star \star}$ & $4,29 * \star$ & $13,76^{\star \star}$ & $163,97^{\star \star}$ & $0,08^{* *}$ \\
\hline Per & 3 & $9077008,97^{\star \star}$ & $88860,35^{\star \star}$ & $2,92^{\star \star}$ & $6,87^{\star \star}$ & $186,39 \star \star$ & $0,18^{\star \star}$ \\
\hline Micro * Per & 15 & $534785,76^{\star \star}$ & $44484,32^{\star \star}$ & 0,19 ** & $0,35 n s$ & $29,67^{\star \star}$ & $0,0042^{\star \star}$ \\
\hline Resíduos & 24 & 471,08 & 201,27 & 0,003 & 0,292 & 2,01 & 0,0000021 \\
\hline Total & 47 & & & & & & \\
\hline
\end{tabular}

Tabela 48. Quadrado médio (Q.M.) da análise de variância, seguido da significância do Teste $F$ dos fatores Microrganismo (Micro), Período (Per) e Interação (Micro * Per) para todas as variáveis em cultivo misto de bactérias tratadas com irradiação e S. cerevisiae

\begin{tabular}{|c|c|c|c|c|c|c|c|}
\hline \multirow{2}{*}{$\begin{array}{l}\text { Fonte de } \\
\text { variação }\end{array}$} & \multirow[b]{2}{*}{ G.L. } & Ac. total & Ac. volátil & $\mathrm{pH}$ & Viabilidade & Brotamento & População \\
\hline & & \multicolumn{6}{|c|}{ Q.M. } \\
\hline Variável & 23 & $6108853,28^{\star \star}$ & $340383,22^{\star \star}$ & $0,54^{\star \star}$ & $17,94^{\star \star}$ & $55,59 * *$ & $0,05^{\star \star}$ \\
\hline Micro & 5 & $12787004,55^{\star \star}$ & $1364905,68^{\star \star}$ & $2,07^{\star \star}$ & $53,05^{\star \star}$ & $57,21^{\star \star}$ & $0,12^{\star *}$ \\
\hline Per & 3 & $23829108,97^{\star \star}$ & $40800,75^{\star \star}$ & $0,57^{\star \star}$ & $7,68^{\star \star}$ & $240,55^{\star \star}$ & $0,06^{\star \star}$ \\
\hline Micro * Per & 15 & $338751,57^{\star \star}$ & $58792,22^{\star \star}$ & $0,02^{\star \star}$ & $8,29^{\star \star}$ & $18,07^{\star \star}$ & $0,02^{\star \star}$ \\
\hline Resíduos & 24 & 3455,2 & 54,08 & 0,0004 & 0,0094 & 0,05 & 0,000002 \\
\hline Total & 47 & & & & & & \\
\hline
\end{tabular}


Tabela 49. Média geral, $\mathrm{R}^{2}$, coeficiente de variação e desvio padrão para as contagens microbiológicas quando em comparação dos meios de cultivo convencionais (PCA, MRSA e YEPDA) e alternativo (MCC-agar) no início $(0 \mathrm{~h})$ do período de incubação das culturas mistas de bactéria e levedura

\begin{tabular}{c|c|c|c|c}
\hline Microrganismo & $\begin{array}{c}\text { Média Geral }(\mathbf{l o g} \\
\text { UFC/mL) }\end{array}$ & $\mathbf{R}^{2}$ & $\begin{array}{c}\text { Coeficiente } \\
\text { de variação }\end{array}$ & Desvio Padrão \\
\hline B. stearothermophilus & 8,88 & 0,9848 & 0,08 & 0,007 \\
\hline B. coagulans & 7,10 & 0,8787 & 0,09 & 0,007 \\
\hline B. subtilis & 7,64 & 0,9689 & 0,12 & 0,009 \\
\hline L. fermentum & 6,59 & 0,9975 & 0,12 & 0,008 \\
\hline L. plantarum & 7,12 & 0,9995 & 0,08 & 0,006 \\
\hline S. cerevisiae & 7,64 & 0,9659 & 0,06 & 0,005 \\
\hline
\end{tabular}

Tabela 50. Média geral, $R^{2}$, coeficiente de variação e desvio padrão para as contagens microbiológicas quando em comparação dos meios de cultivo convencionais (PCA, MRSA e YEPDA) e alternativo (MCC-agar) no final (72 h) do período de incubação das culturas mistas de bactéria e levedura

\begin{tabular}{c|c|c|c|c}
\hline Microrganismo & $\begin{array}{c}\text { Média Geral } \mathbf{( l o g} \\
\text { UFC/mL) }\end{array}$ & $\mathbf{R}^{2}$ & $\begin{array}{c}\text { Coeficiente } \\
\text { de variação }\end{array}$ & Desvio Padrão \\
\hline B. stearothermophilus & 8,45 & 0,9921 & 0,06 & 0,005 \\
\hline B. coagulans & 7,89 & 0,9942 & 0,05 & 0,004 \\
\hline B. subtilis & 8,79 & 0,9990 & 0,04 & 0,004 \\
\hline L. fermentum & 6,85 & 0,9941 & 0,06 & 0,004 \\
\hline L. plantarum & 7,22 & 0,9996 & 0,07 & 0,005 \\
\hline S. cerevisiae & 8,61 & 0,9905 & 0,05 & 0,005 \\
\hline
\end{tabular}

Tabela 51. Quadrado médio (Q.M.) da análise de variância, seguido da significância do Teste $F$ para as contagens microbiológicas quando em comparacão dos meios de cultivo convencionais (PCA, MRSA e YEPDA) e alternativo (MCC-agar) no início $(0 \mathrm{~h})$ do período de incubação das culturas mistas de bactérias e $S$. cerevisiae

\begin{tabular}{|c|c|c|c|c|c|c|c|}
\hline \multirow[t]{2}{*}{$\begin{array}{l}\text { Fonte de } \\
\text { variação }\end{array}$} & \multirow[t]{2}{*}{ G.L. } & $\begin{array}{c}\text { Bacillus } \\
\text { stearothermophilus }\end{array}$ & $\begin{array}{c}\text { Bacillus } \\
\text { coagulans }\end{array}$ & $\begin{array}{l}\text { Bacillus } \\
\text { subtilis }\end{array}$ & $\begin{array}{l}\text { Lactobac. } \\
\text { fermentum }\end{array}$ & $\begin{array}{l}\text { Lactobac. } \\
\text { plantarum }\end{array}$ & S. cerevisiae \\
\hline & & \multicolumn{6}{|c|}{ Q.M. } \\
\hline $\begin{array}{c}\text { Meios de } \\
\text { cultivo }\end{array}$ & 1 & $0,0671^{\star \star}$ & $0,0061^{\star \star}$ & $3,13^{\star *}$ & 0,4868 ** & $1,541^{\star \star}$ & $0,0109^{* *}$ \\
\hline Resíduos & 34 & 0,00005 & 0,000038 & 0,02 & 0,00006 & 0,00004 & 0,00002 \\
\hline Total & 35 & & & & & & \\
\hline
\end{tabular}

Tabela 52. Quadrado médio (Q.M.) da análise de variância, seguido da significância do Teste $F$ para as contagens microbiológicas quando em comparação dos meios de cultivo convencionais (PCA, MRSA e YEPDA) e alternativo (MCC-agar) no final $(72 \mathrm{~h})$ do período de incubação das culturas mistas de bactérias e $S$. cerevisiae

\begin{tabular}{|c|c|c|c|c|c|c|c|}
\hline \multirow[t]{2}{*}{$\begin{array}{l}\text { Fonte de } \\
\text { variação }\end{array}$} & \multirow[t]{2}{*}{ G.L. } & $\begin{array}{c}\text { Bacillus } \\
\text { stearothermophilus }\end{array}$ & $\begin{array}{c}\text { Bacillus } \\
\text { coagulans }\end{array}$ & $\begin{array}{l}\text { Bacillus } \\
\text { subtilis }\end{array}$ & $\begin{array}{l}\text { Lactobac. } \\
\text { fermentum }\end{array}$ & $\begin{array}{l}\text { Lactobac. } \\
\text { plantarum }\end{array}$ & S. cerevisiae \\
\hline & & \multicolumn{6}{|c|}{ Q.M. } \\
\hline $\begin{array}{l}\text { Meios de } \\
\text { cultivo }\end{array}$ & 1 & $0,0588^{* *}$ & $0,0382^{\star \star}$ & $0,2214^{* *}$ & 0,0536 ** & $1,1878^{\star \star}$ & $0,0372^{\star \star}$ \\
\hline Resíduos & 34 & 0,00003 & 0,00001 & 0,000009 & 0,00002 & 0,00002 & 0,00002 \\
\hline Total & 35 & & & & & & \\
\hline
\end{tabular}

